\title{
Central African Republic: Fourth Review Under the Three-Year Arrangement Under the Poverty Reduction and Growth Facility and Request for Waiver of Nonobservance of Performance Criterion, Modification of Performance Criteria, Augmentation of Access, Extension of Arrangement, and Financing Assurances Review_-Staff Report; Press Release on the Executive Board Discussion; and Statement by the Executive Director for Central African Republic
}

In the context of the Fourth Review Under the Three-Year Arrangement Under the Poverty Reduction and Growth Facility and Request for Waiver of Nonobservance of Performance Criterion, Modification of Performance Criteria, Augmentation of Access, Extension of Arrangement, and Financing Assurances Review, the following documents have been released and are included in this package:

- $\quad$ The staff report for the Fourth Review Under the Three-Year Arrangement Under the Poverty Reduction and Growth Facility and Request for Waiver of Nonobservance of Performance Criterion, Modification of Performance Criteria, Augmentation of Access, Extension of Arrangement, and Financing Assurances Review, prepared by a staff team of the IMF, following discussions that ended on April 16, 2009, with the officials of Central African Republic on economic developments and policies. Based on information available at the time of these discussions, the staff report was completed on June 9, 2009. The views expressed in the staff report are those of the staff team and do not necessarily reflect the views of the Executive Board of the IMF.

- $\quad$ A Press Release summarizing the views of the Executive Board as expressed during its June 29, 2009 discussion of the staff report that completed the review.

- $\quad$ A statement by the Executive Director for Central African Republic.

The documents listed below have been or will be separately released.

Enhanced Heavily Indebted Poor Countries (HIPC) Initiative-Completion Point Document and Multilateral Debt Relief Initiative (MDRI)

Letter of Intent sent to the IMF by the authorities of Central African Republic*

Memorandum of Economic and Financial Policies by the authorities of Central African Republic*

Technical Memorandum of Understanding*

Poverty Reduction Strategy Paper-First Annual Progress Report

Joint Staff Advisory Note of the Poverty Reduction Strategy Paper

*Also included in Staff Report

The policy of publication of staff reports and other documents allows for the deletion of market-sensitive information.

Copies of this report are available to the public from

International Monetary Fund • Publication Services

$70019^{\text {th }}$ Street, N.W. • Washington, D.C. 20431

Telephone: (202) 623-7430 • Telefax: (202) 623-7201

E-mail: publications@imf.org •Internet: http://www.imf.org

\section{International Monetary Fund \\ Washington, D.C.}



INTERNATIONAL MONETARY FUND

CENTRAL AFRICAN REPUBLIC

\title{
Fourth Review Under the Three-Year Arrangement Under the Poverty Reduction and Growth Facility, Requests for Waiver of Nonobservance of Performance Criterion, Modification of Performance Criteria, Augmentation of Access, Extension of Arrangement, and Financing Assurances Review
}

\author{
Prepared by the African Department \\ (in consultation with other departments)
}

Approved by Michael Atingi-Ego and Dhaneshwar Ghura

June 9, 2009

Fund relations:

Mission discussions:

Mission team:

Location and dates:

Interlocutors:
In December 2006 the Executive Board approved a three-year PRGF arrangement for the Central African Republic (C.A.R.) in an amount equivalent to SDR 36.2 million (65 percent of quota). C.A.R. reached the decision point under the enhanced Heavily Indebted Poor Countries (HIPC) Initiative in September 2007. An augmentation of SDR 8.355 million (15 percent of quota) was approved in June 2008. The third PRGF review was completed in December 2008.

Program performance in 2008 was broadly satisfactory. The authorities requested an augmentation of SDR 25.065 million (45 percent of quota) and a program extension. Upon approval, SDR 14.24 million would become available with this review, including SDR 11.14 million from the augmentation.

Mr. Petri (head), Mr. Keller, Mr. Kinoshita, and Mr. Hitakatsu (all AFR). Mr. Ntamatungiro (resident representative) assisted, and the World Bank participated.

Bangui, April 2-16, 2009

President General Bozizé; Prime Minister Touadéra; Minister of State for Planning, Economy, and International Cooperation Maliko; Minister of State for Mining, Energy, and Hydrology Ndoutingaï; Minister of Finance and Budget Besse; Minister Delegate for Resource Mobilization Kadre; National Director of BEAC Kéléfio; other senior officials; parliamentarians; and representatives of the press, donors, and the business community. 


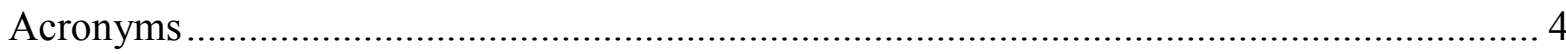

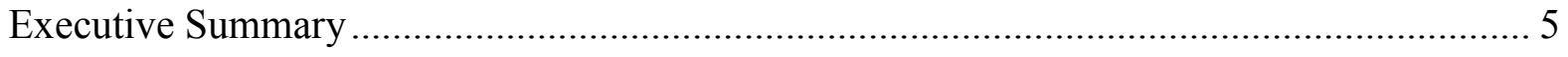

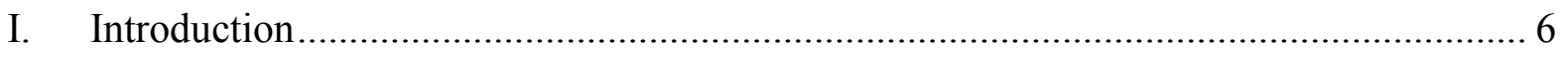

II. Economic Developments and Program Performance ................................................ 6

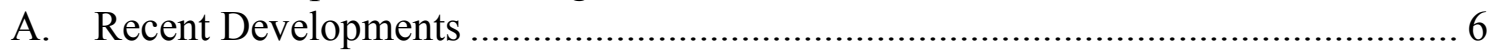

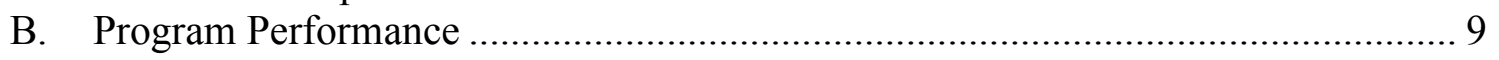

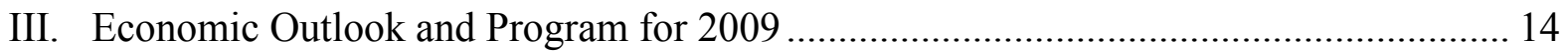

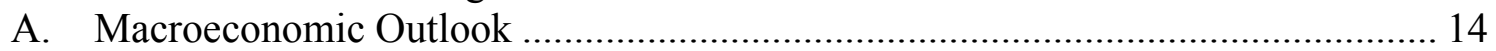

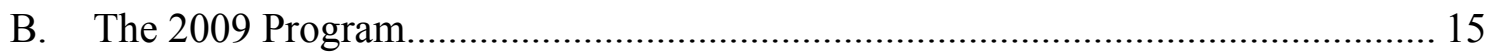

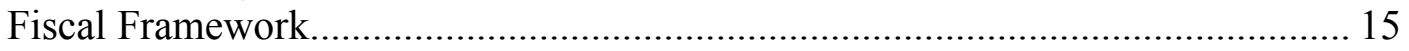

Structural Reforms .............................................................................. 18

IV. Program Access, Financing, and Monitoring ....................................................... 20

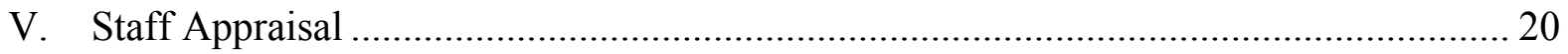

Box

1. Impact of the Global Slowdown on Forestry ......................................................... 14

\section{Text Tables}

1. Quantitative Performance Criteria and Benchmarks Under the PRGF Arrangement, 2008 ................................................................................... 10

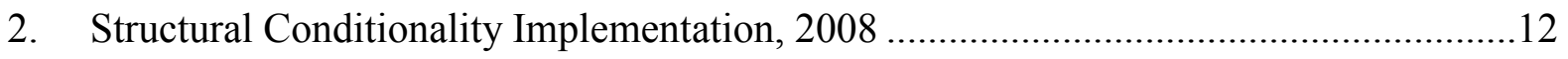

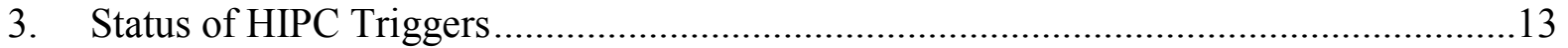

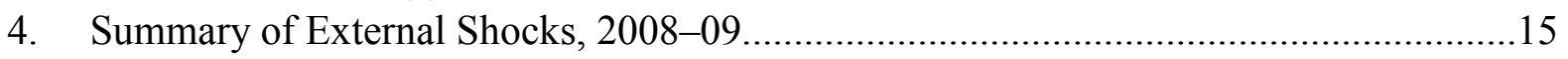

5. Key Fiscal Variables and Program Revisions, 2008-09...........................................17

Figures

1. Export Volumes of Main Commodities, January 2007-March 2009 ............................7

2. Growth and Inflation Developments, 2003-08 ........................................................... 7

3. CPI Inflation by Product Categories, January 2003-March 2009 ................................8

4. External and Monetary Developments, 2003-08....................................................

5. Revenue and Expenditure Developments, 2003-08 ….............................................11

6. Fiscal Balance and Debt Developments, 2003-08 .....................................................11

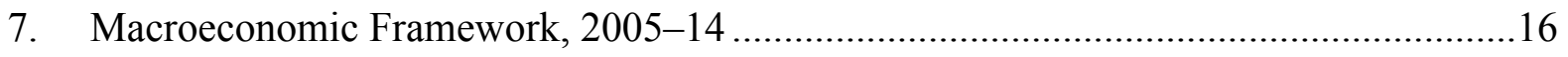

8. Indicators of Public Debt Under Alternative Scenarios, 2009-29...............................19 


\section{Tables}

1. Selected Economic and Financial Indicators, 2005-14 ............................................22

2. Central Government Operations, 2005-14 ............................................................23

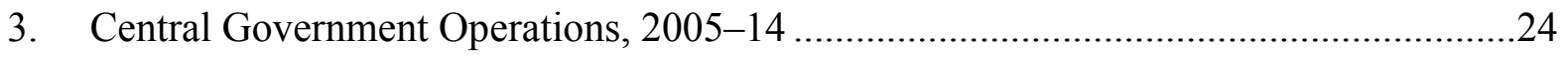

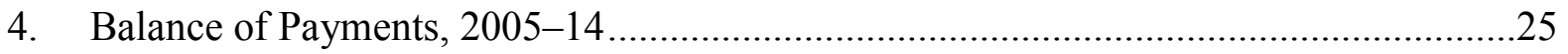

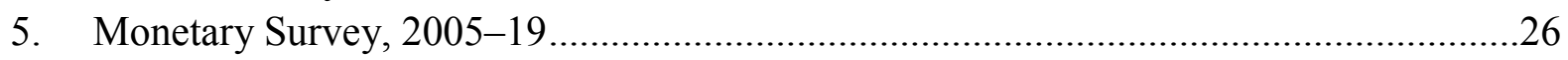

6. Access and Phasing Under the Three-Year PRGF Arrangement ................................27

7. Indicators of Capacity to Repay the Fund, 2008-18 ................................................28

Appendix

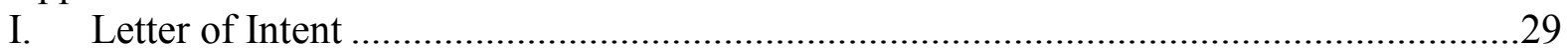

Attachments

I. Memorandum of Economic and Financial Policies, 2008-09 ......................... 31

II. Technical Memorandum of Understanding ................................................44

Appendix Tables

I.1. Quantitative Performance Criteria and Benchmarks under the

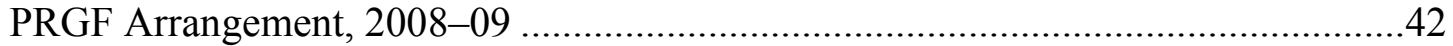

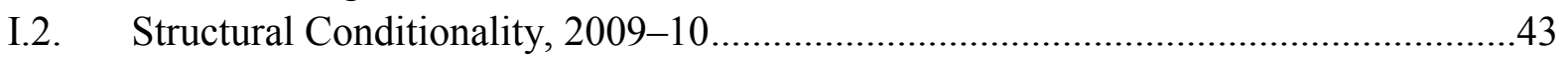




\section{ACRONYMS}

$\begin{array}{ll}\text { AfDB } & \begin{array}{l}\text { African Development Bank } \\ \text { BEAC }\end{array} \\ \text { Canque des États de l'Afrique Centrale } \\ \text { (Bank of Central African States) } \\ \text { Communauté Économique et Monétaire de l'Afrique Centrale } \\ \text { (Economic and Monetary Community of Central Africa) } \\ \text { DDR } & \text { Disarmament, demobilization, and reintegration } \\ \text { DSA } & \text { Debt Sustainability Analysis } \\ \text { FDI } & \text { Foreign direct investment } \\ \text { FSAP } & \text { Financial Sector Assessment Program } \\ \text { GFMIS } & \text { Government Financial Management Information System } \\ \text { HIPC } & \text { Heavily indebted poor countries } \\ \text { LIC } & \text { Low-income countries } \\ \text { MDRI } & \text { Multilateral Debt Relief Initiative } \\ \text { MEFP } & \text { Memorandum of Economic and Financial Policies } \\ \text { NFA } & \text { Net foreign assets } \\ \text { QB } & \text { Quantitative benchmark } \\ \text { PEFA } & \text { Public expenditure and financial accountability } \\ \text { PFM } & \text { Public financial management } \\ \text { PRGF } & \text { Poverty Reduction and Growth Facility } \\ \text { PC } & \text { Performance criterion } \\ \text { SB } & \text { Structural benchmark } \\ \text { SOE } & \text { State-owned enterprise } \\ \text { TMU } & \text { Technical Memorandum of Understanding } \\ \text { TSA } & \text { Treasury Single Account } \\ & \end{array}$




\section{EXECUTIVE SUMMARY}

C.A.R. suffered major shocks in 2008. Electricity outages and a plunge in timber and diamond exports reduced real GDP growth to 2.2 percent; inflation reached 9.3 percent. Nevertheless, fiscal performance was broadly satisfactory. The increase in the tax-to-GDP ratio was particularly noteworthy. The peace process is advancing slowly and could benefit from additional donor resources.

Structural reforms advanced despite delays. The automatic adjustment mechanism for fuel products implemented in January and April 2009 will offset some crisis-related revenue losses. Public financial management (PFM) was strengthened through installation of a government financial management information system (GFMIS); debt management was enhanced; and tax audits were pursued systematically.

In 2009 real GDP growth is projected at 2 $\frac{1}{2}$ percent - significantly lower than expected. Average inflation is projected at 4.7 percent. Total exports are 40 percent lower than programmed; imports would also be severely compressed. The current account deficit is projected to be almost 10 percent of GDP, although world oil prices have dropped. With reduced private financial inflows, official foreign reserves would drop to 2.6 months of imports even with the requested augmentation of access.

Short-term fiscal policy attempts to stabilize demand through government spending while preserving medium-term fiscal discipline. The revised program safeguards budgeted spending and incorporates new externally financed peace-process spending. The domestic primary surplus, lower by 1.6 percentage points of GDP compared to the original program, is being financed primarily by additional grants; the overall fiscal cash balance without HIPC debt relief is unchanged.

Structural reforms are focused on areas critical to economic stability and the recovery of growth; they target revenue generation, PFM, and public enterprise reform.

Staff supports completion of the fourth review, augmentation of PRGF access, and program extension. The implementation of the program has been broadly satisfactory despite a difficult political and economic situation; and policy implementation capacity is being significantly strengthened. Staff also supports a waiver for the performance criterion (PC) on commercial bank credit (minor deviation). 


\section{INTRODUCTION}

1. The global financial crisis is stunting C.A.R.'s short-term growth prospects, mainly because the main exports, timber and diamonds, are plunging. Lower employment in and tax revenues from these two sectors make it harder for C.A.R. to implement its poverty reduction strategy.

2. The peace process has advanced, but its financing is materializing slowly. The inclusive political dialogue in December 2008 led to participation of the political opposition in the cabinet formed in January 2009 under the continued leadership of Prime Minister Touadéra. Most spending for disarmament, demobilization, and reintegration (DDR) will be externally financed. Financing from the UN and CEMAC has been identified, although more is likely to be needed. Elections in early 2010 could add to political uncertainty in coming months.

3. The government is stepping up structural reforms to foster medium-term growth. Certainly, the ability to generate domestic revenues and to control expenditure has improved significantly. New measures will reduce discretionary customs exemptions, facilitate VAT refunds, strengthen tax audits, and fully implement the GFMIS. The new forestry and mining codes should stimulate private sector development, but additional donor support is needed to rehabilitate infrastructure.

\section{ECONomic Developments And Program Performance}

\section{A. Recent Developments}

4. The C.A.R. economy suffered major shocks in 2008. Breakdowns at the main hydro power plant caused recurrent outages that had serious economic and social effects. The situation has stabilized, but the power supply is still fragile, substantially below demand, and the biggest bottleneck for growth. Because falling global demand caused a plunge in timber and diamond exports (80 percent of goods exports, Figure 1), real GDP growth for 2008 has been revised downward from the 3.5 percent expected to 2.2 percent (Figure 2).

5. Food and fuel price shocks pushed up inflation. Average CPI inflation - food and fuel have dominant weight in the index - reached 9.3 percent in 2008 (Figure 3), much higher than the CEMAC average, which raises concerns about competitiveness. 
Figure 1. Central African Republic: Export Volume of Main Commodities, January 2007-March 2009

Exports of timber and diamonds fell by more than one-third year-on-year in volume terms during the last six months shown.

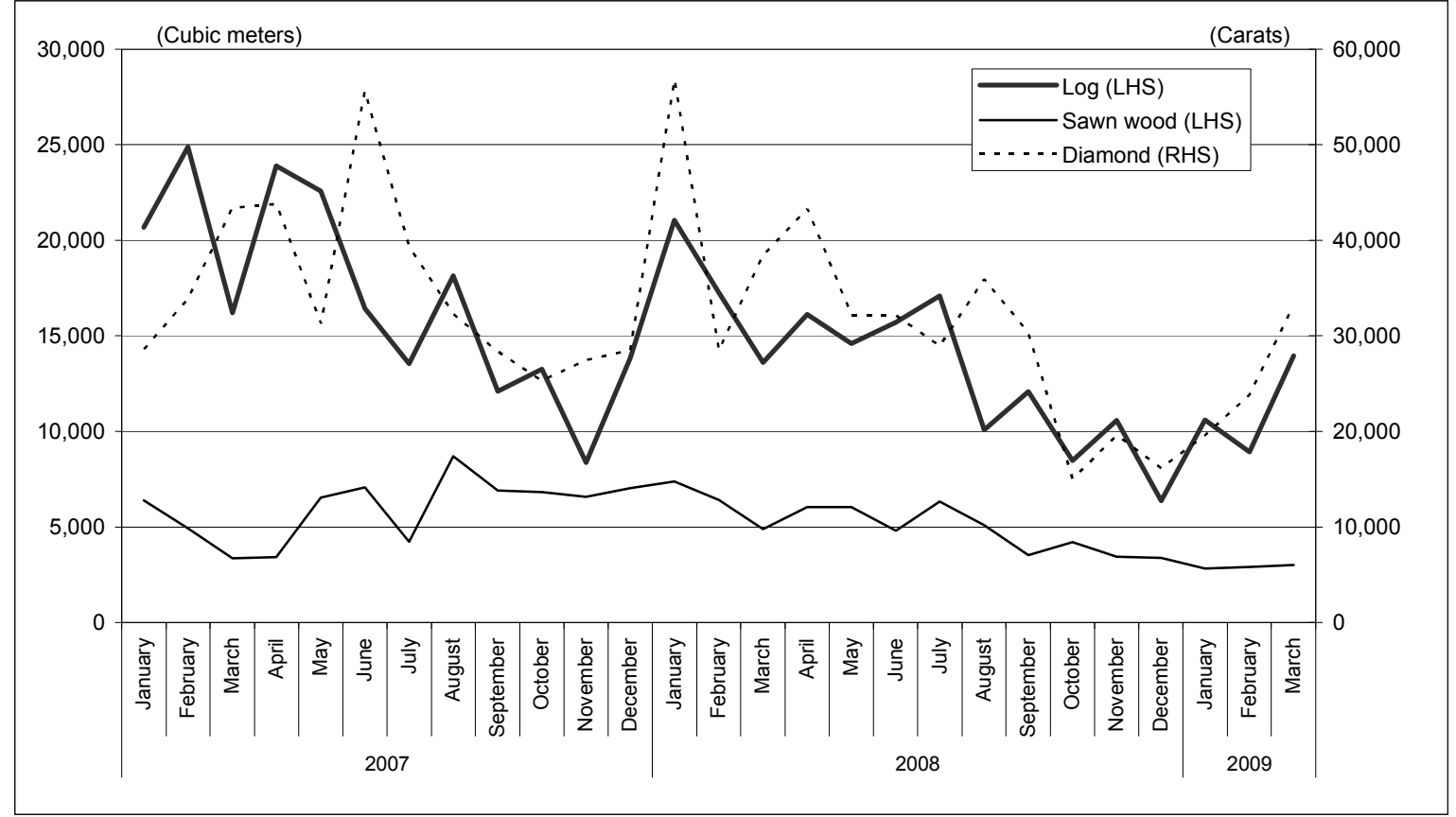

Sources: C.A.R. authorities; and IMF staff estimates.

Figure 2. Central African Republic: Growth and Inflation Developments, 2003-08

Growth slowed reflecting the global crisis; inflation increased due to food and fuel prices.
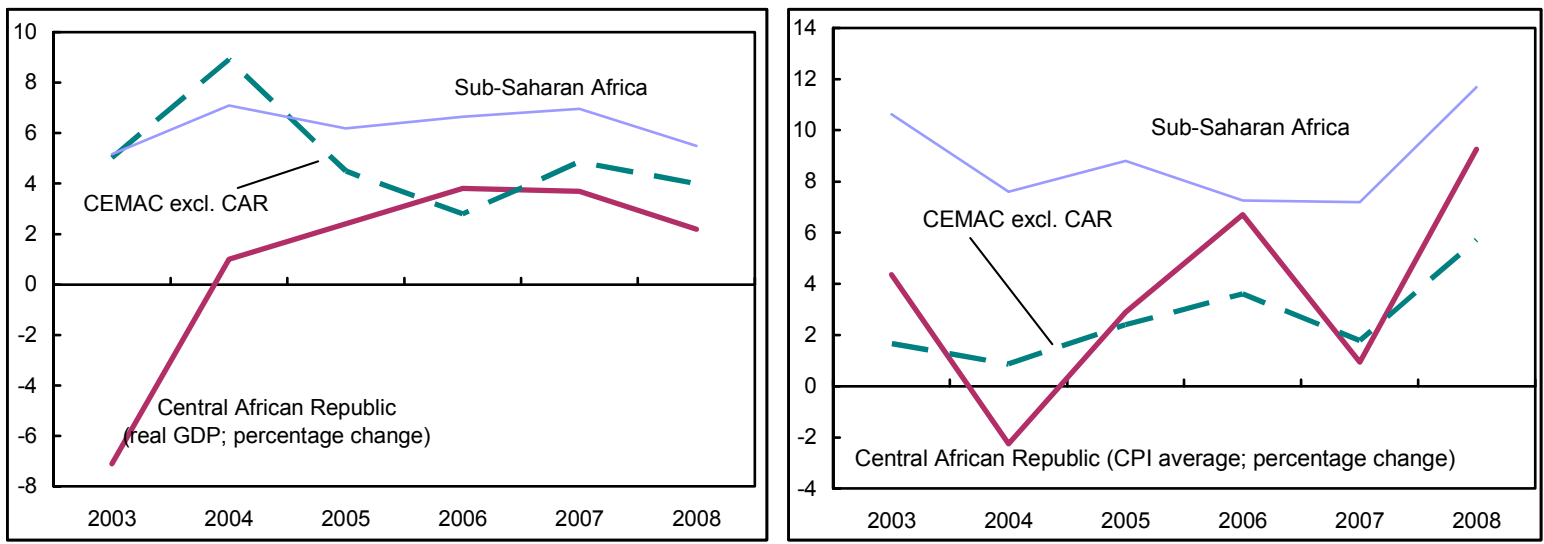

Sources: C.A.R. authorities; and IMF staff estimates. 
Figure 3. Central African Republic: CPI Inflation by Products, January 2003-March 2009

Inflation accelerated due to a food and fuel price surge, but has moderated in recent months.
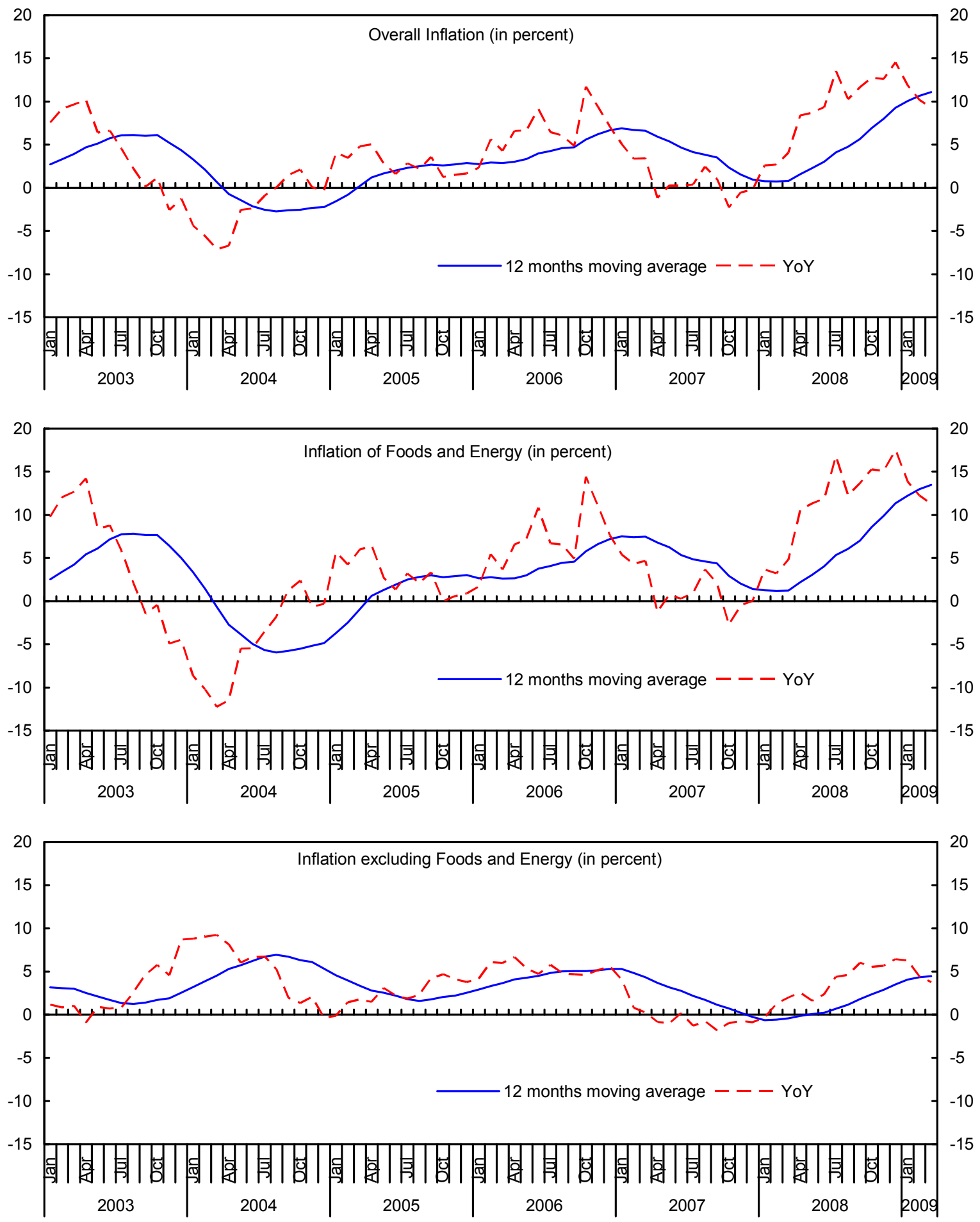

Sources: C.A.R. authorities; and IMF staff estimates. 
6. The external current account deteriorated in 2008, but gross reserves increased. Imports increased because of surges in fuel prices, and exports declined, particularly in the second half of 2008. The current account deficit worsened by about $3 \frac{1}{2}$ percentage points to 10 percent of GDP ( 1 percentage point more than programmed), mostly due to trade developments. Thanks to inflows of foreign direct investment (FDI) and short-term private capital, the balance of payments was about balanced and net foreign assets (NFA) were stable. IMF disbursements and sales of foreign exchange by commercial banks to the central bank (BEAC) facilitated some buildup in gross official reserves. Broad money grew by 16.5 percent, mostly because net domestic assets and demand for currency both increased.

Figure 4. Central African Republic: External and Monetary Developments, 2003-08

The current account balance deteriorated substantially, but net foreign assets were stable because of strong FDI.
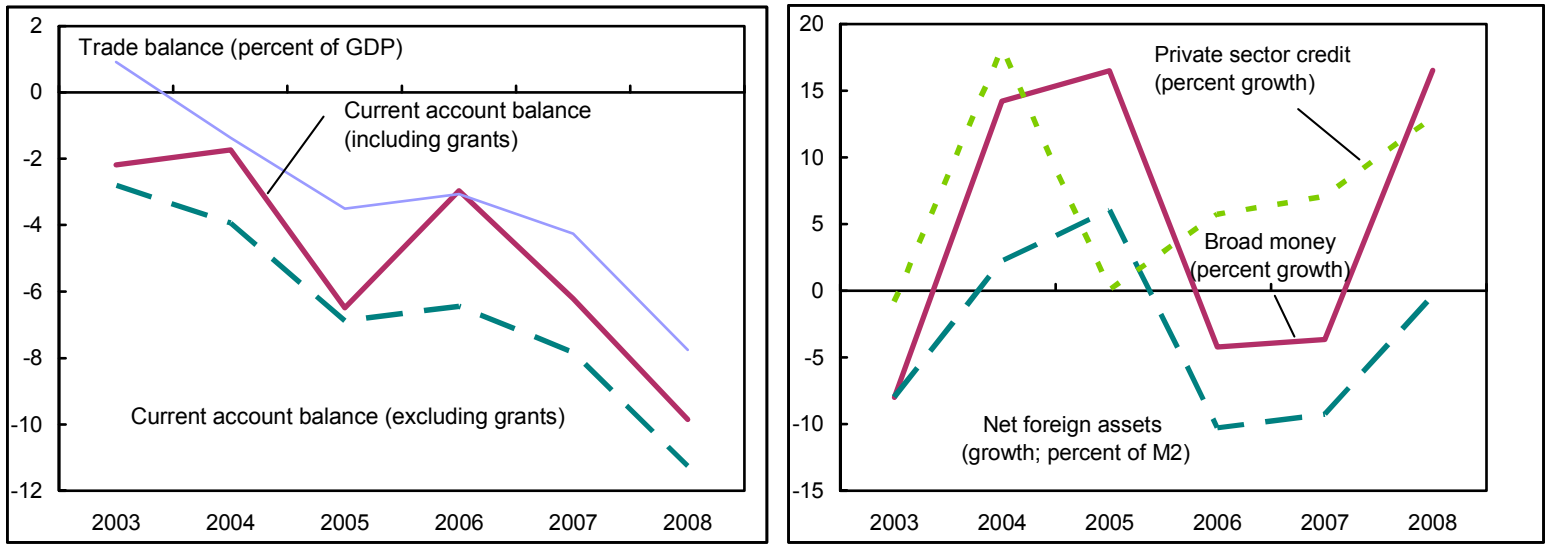

Sources: C.A.R. authorities; and IMF staff estimates.

\section{B. Program Performance}

7. Fiscal performance was in line with the program. The performance criterion (PC) on domestic revenues was met (Text Table 1) - an encouraging sign given that it was raised during the third review. Revenue reforms appear to be having positive effects despite the economic shocks; the revenue-to-GDP ratio increased to 10.4 percent of GDP from 8.2 percent in 2005 (Figure 5). Together with tight controls on expenditures, the domestic primary surplus target was met (Figure 6). Net credit from commercial banks narrowly missed the PC ceiling (less than 0.1 percent of GDP) mainly related to a delayed transfer of the IMF disbursement from BEAC to the C.A.R. treasury. Net accumulation of tax arrears (quantitative benchmark (QB)) was somewhat higher than targeted due to poor performance of public enterprises; all other QBs were met. 
Text Table 1. Central African Republic: Quantitative Performance Criteria and Benchmarks under the PRGF Arrangement, 2008 (billions of CFA francs; cumulative from December 31, 2007; ceilings, unless otherwise indicated)

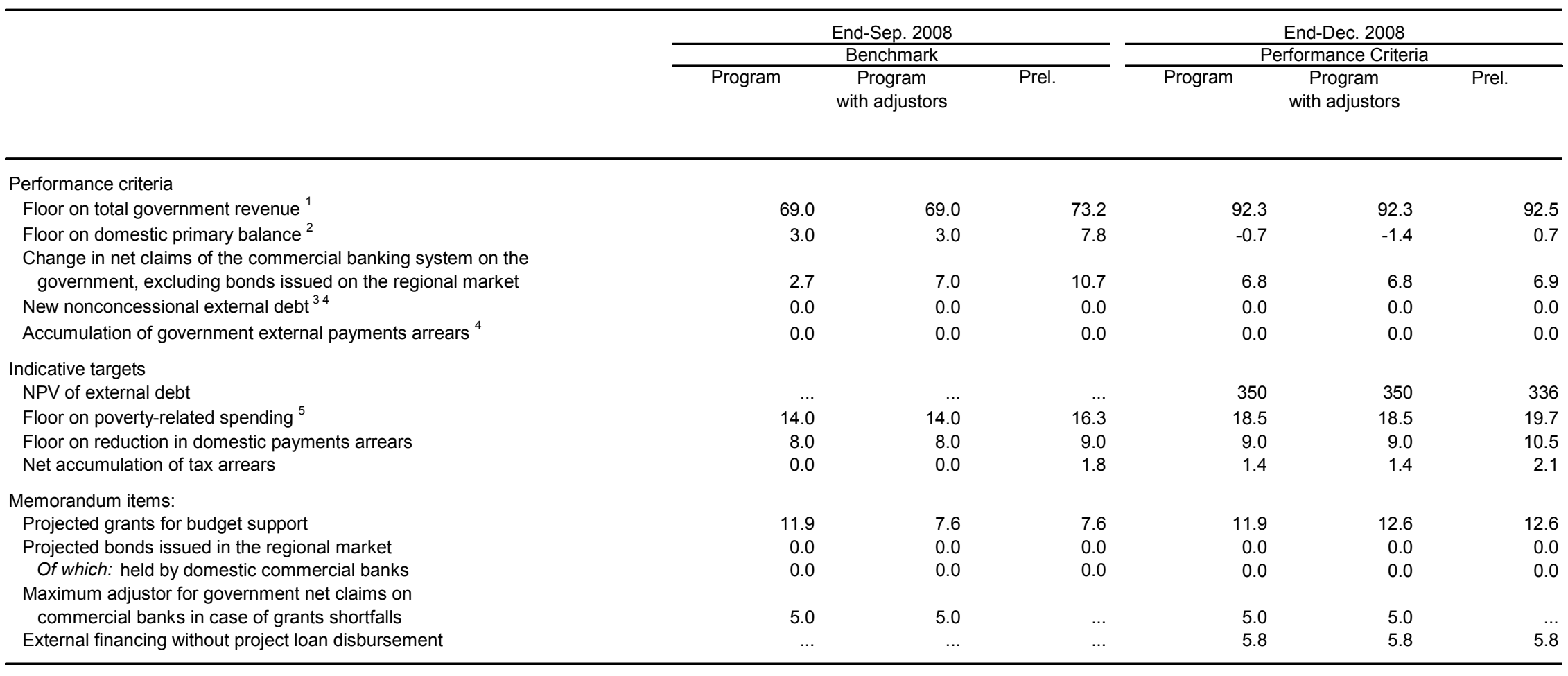

Sources: C.A.R. authorities; and IMF staff estimates.

${ }^{1}$ Domestic revenue, which excludes foreign grants and divestiture receipts (see the Technical Memorandum of Understanding, TMU, for more details).

${ }^{2}$ The domestic primary balance (cash basis) is defined as the difference between government domestic revenue and government total expenditure,

less all interest payments and externally-financed capital expenditures.

${ }^{3}$ Contracted or guaranteed by the government (see the TMU).

${ }^{4}$ These performance criteria will be monitored continuously.

${ }^{5}$ Total spending on health and education including wages and salaries and goods and services. 
Figure 5. Central African Republic: Revenue and Expenditure Developments, 2003-08

Domestic revenue is on an upward path; budgeted spending is becoming less compressed allowing arrears to decline.
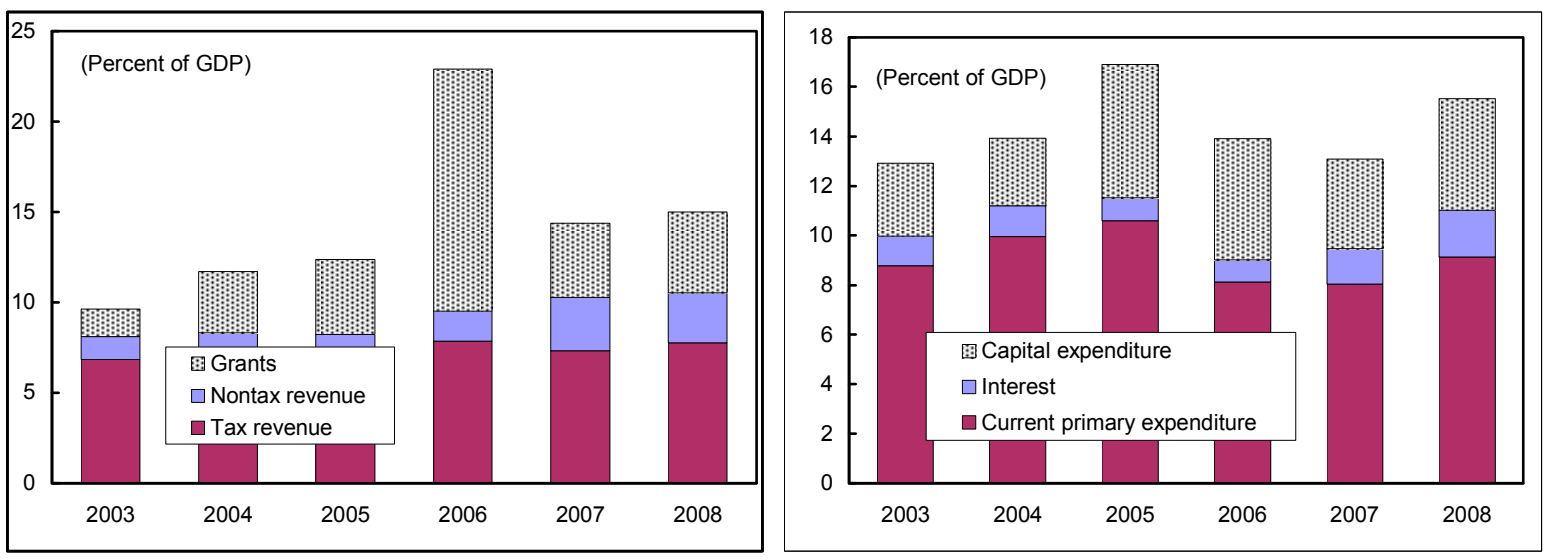

Sources: C.A.R. authorities; and IMF staff estimates.

Figure 6. Central African Republic: Fiscal Balance and Debt Developments, 2003-08

Small domestic primary surpluses are maintained; total debt continues to decline thanks to debt relief.
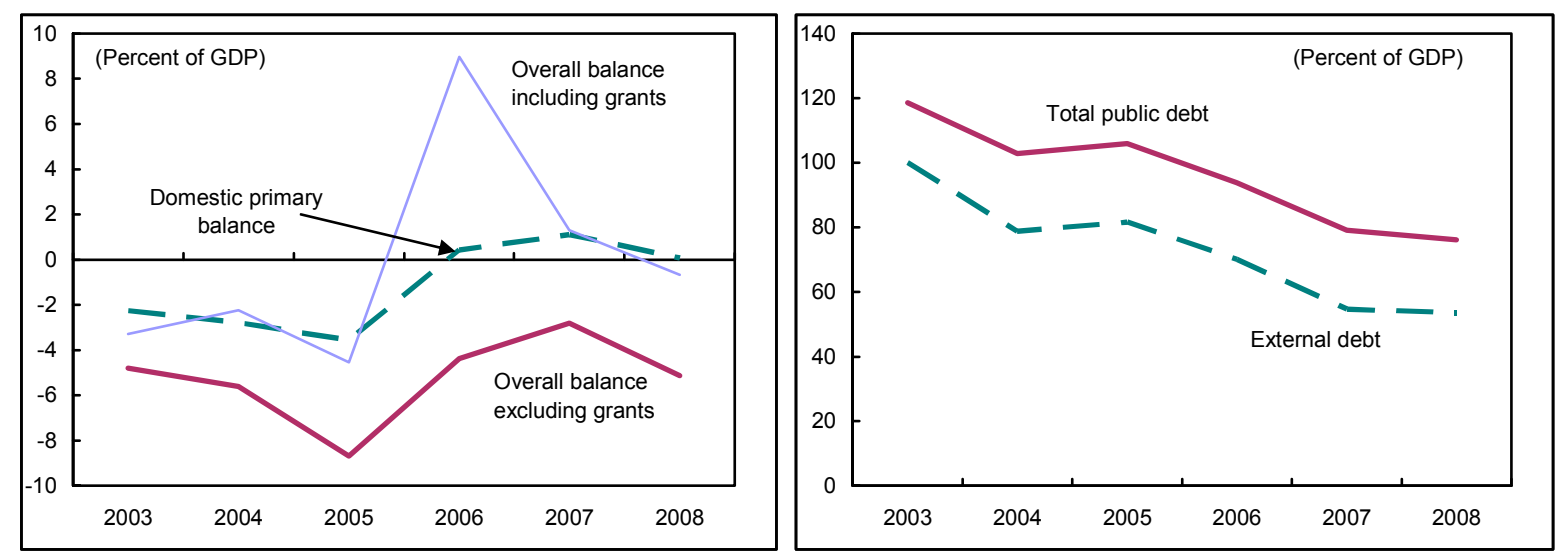

Sources: C.A.R. authorities; and IMF staff estimates.

8. The authorities have moved to improve revenues: In April 2009, the government harmonized the turnover thresholds for large taxpayers and VAT, a structural benchmark (SB) observed with delays to receive advice from the AFRITAC/FAD experts (Text Table 2; MEFP \10). Also, the SB on tax audits was implemented (with a short delay), and the new audit department should reinforce auditing capacity. The continuous structural PC on the fuel price adjustment mechanism was observed, thus eliminating subsidies for kerosene in April 2009. ${ }^{1}$

\footnotetext{
${ }^{1}$ The continuous structural PC will be converted into a continuous SB in line with recent changes to conditionality.
} 
9. Capacity for debt management and PFM improved. The authorities installed the UNCTAD debt management software in 2008, and incorporated all external and standard domestic debt into the database. The system can generate reliable and timely debt service projections using different assumptions (SB). The authorities have started publishing an official debt bulletin. Introduction of a GFMIS called Gesco for the budget was a major achievement.

Text Table 2. Central African Republic: Structural Conditionality Implementation, 2008

\begin{tabular}{|c|c|c|c|}
\hline Measure & $\begin{array}{l}\text { Conditionality } \\
\text { Timeline }\end{array}$ & $\begin{array}{l}\text { Macroeconomic } \\
\text { Rationale }\end{array}$ & Implementation Status \\
\hline \multicolumn{4}{|l|}{ GOVERNMENT REVENUES } \\
\hline $\begin{array}{l}\text { Continue applying the automatic quarterly } \\
\text { petroleum product pricing formula that ensures } \\
\text { full pass-through to the consumer of all costs, } \\
\text { distribution margins, VAT, and a specific excise } \\
\text { by product. The formula includes a timetable for } \\
\text { petroleum taxation. }\end{array}$ & $\begin{array}{l}\text { Continuous } \\
\text { structural } \\
\text { performance } \\
\text { criterion }\end{array}$ & $\begin{array}{l}\text { Protect the budget from } \\
\text { risks of fluctuating } \\
\text { petroleum prices; create } \\
\text { room for well-targeted } \\
\text { measures to mitigate the } \\
\text { social impact of } \\
\text { petroleum price changes. }\end{array}$ & $\begin{array}{l}\text { Met for January and April } \\
2009 . \text { Kerosene and fuel } \\
\text { oil prices were increased } \\
\text { in January 2009. Subsidies } \\
\text { on kerosene were } \\
\text { eliminated in April } 2009 .\end{array}$ \\
\hline $\begin{array}{l}\text { Use turnover as the sole criterion for taxpayer } \\
\text { classification with a turnover of CFAF } 30 \text { million } \\
\text { as the minimum threshold for large taxpayers, } \\
\text { VAT registration, and the standard tax system. }\end{array}$ & $\begin{array}{l}\text { Structural } \\
\text { benchmark/ } \\
\text { end- } \\
\text { December } \\
2008\end{array}$ & $\begin{array}{l}\text { Enhance revenue } \\
\text { generation potential by } \\
\text { focusing on large } \\
\text { taxpayers and streamline } \\
\text { the structure of VAT, the } \\
\text { largest revenue source. }\end{array}$ & $\begin{array}{l}\text { Not met. Implemented in } \\
\text { April } 2009 \text { to consult with } \\
\text { FAD/ AFRITAC experts on } \\
\text { implementation. Minor } \\
\text { legal amendment to be } \\
\text { introduced with revised } \\
2009 \text { budget (MEFP } \$ 10) \text {. }\end{array}$ \\
\hline $\begin{array}{l}\text { Increase the number of audits in } 2008 \text { to cover } \\
\text { (i) at least } 30 \text { percent of large taxpayers per } \\
\text { year; (ii) all stop-filers; and (iii) all filers with VAT } \\
\text { credit claims or zero balance returns. }\end{array}$ & $\begin{array}{l}\text { Structural } \\
\text { benchmark/ } \\
\text { end- } \\
\text { December } \\
2008\end{array}$ & $\begin{array}{l}\text { Enhance revenue } \\
\text { generation potential by } \\
\text { reducing the scope for } \\
\text { tax evasion. }\end{array}$ & $\begin{array}{l}\text { Met for items (i) and (ii). } \\
\text { Not met for item (iii), which } \\
\text { was implemented in } \\
\text { February 2009, when the } \\
\text { few remaining VAT audits } \\
\text { were completed. }\end{array}$ \\
\hline \multicolumn{4}{|l|}{ PUBLIC FINANCIAL MANAGEMENT } \\
\hline $\begin{array}{l}\text { Fully computerize the debt management unit } \\
\text { and enable it to provide debt service projections } \\
\text { for various scenarios. }\end{array}$ & $\begin{array}{l}\text { Structural } \\
\text { benchmark/ } \\
\text { end- } \\
\text { December } \\
2008\end{array}$ & $\begin{array}{l}\text { Increase the reliability of } \\
\text { debt forecasts and } \\
\text { develop ability to take } \\
\text { early corrective actions to } \\
\text { maintain medium-term } \\
\text { debt sustainability. }\end{array}$ & $\begin{array}{l}\text { Met for computerization; } \\
\text { not met for ability to run } \\
\text { scenarios, which was } \\
\text { implemented in February. } \\
\text { A debt statistics bulletin is } \\
\text { about to be published. }\end{array}$ \\
\hline
\end{tabular}

Sources: C.A.R. authorities; IMF staff assessment.

10. The authorities have completed the triggers for the HIPC completion point, but assurances of creditor participation have not yet reached the usual 80 percent threshold. Floating triggers for macroeconomic management (PFM, procurement, and debt management) were met (Text Table 3), reflecting the government's firm commitment in this area. The reforms made in forestry and mining will help sustain economic and export growth. Health, education, and governance reforms will support poverty reduction. Creditors representing 78 percent of eligible HIPC debt have indicated their willingness to provide debt relief. The authorities and staff are actively trying to convince other creditors to participate. 
Text Table 3. Central African Republic: Status of HIPC Triggers

\begin{abstract}
Definition of HIPC trigger
PRSP: Preparation of a full PRSP through a participatory process and its satisfactory implementation for at least one year, as evidenced by an Annual Progress Report that has been the subject of analysis in a Joint Staffs Advisory Note.

Macroeconomic stability: Maintenance of macroeconomic stability as evidenced by satisfactory performance under the PRGF-supported program.

Transparency: Satisfactory implementation of (i) the provision of articles 44 and 75 of the Constitution linked to asset declaration and disclosure by the Prime Minister, members of the Government and members of the Constitutional Court; (ii) a new decree extending the obligation of asset declaration and disclosure to senior public enterprise officials and some key senior civil servants.
\end{abstract}

Status

Forestry sector: Improve the regulatory oversight and reporting framework through: (i) adoption by Parliament of a satisfactory new forestry code and issue of some key ministerial decrees on its implementing regulations, and their satisfactory implementation; and (ii) undertaking an awareness campaign for communities and the establishment of a standing public information system.

Mining sector: Improve the regulatory oversight and reporting framework through: (i) publication on the government's internet site of the report of the Extractive Industries Transparency Initiative (EITI) administrator on mining revenue starting from 2006; and (ii) adoption by Presidential decree of a satisfactory standard-form agreement for mining, and adoption by Parliament of satisfactory amendments to the mining code to ensure their consistency.

Public financial management: Improve the effectiveness, transparency, and accountability in public financial management, particularly through: (i) preparation and submission to Parliament of the budget using the new nomenclature; (ii) satisfactory implementation of a new expenditure tracking system from commitment to authorization (using the new budget nomenclature) within the General Budget Directorate; (iii) satisfactory implementation of the new payroll management system; and (iv) adoption by Parliament of a satisfactory new procurement code and the start of its satisfactory implementation.

Civil service reform: Begin civil service reform by (i) the adoption by the Cabinet of a satisfactory new organic framework consistent with the PRSP objectives, based on organizational audits; and (ii) the submission to the inter-ministerial committee of satisfactory new rules with a corresponding compensation and performance assessment system.

Public debt management: Improve public debt management through (i) the establishment by the Debt Management Unit (Direction de la Dette) of satisfactory procedures for, and maintenance of, an accurate, comprehensive, and secure database of public- and publicly-guaranteed debt (domestic and external), and (ii) satisfactory implementation of periodic publication of public- and publicly-guaranteed debt data (stocks, debt service projections, and key debt ratios) within six months after the end of the fiscal year.

Education: (i) at least 750 additional teachers will be teaching at the primary level compared to 2006-07 levels; and (ii) implementation of educational and administrative measures making it possible to achieve a repetition rate of less than 20 percent at the primary level in areas where schools are operating normally.

Health: (i) keep DPT3 vaccination rates at 80 percent or higher; and (ii) distribute at least 300,000 treated Implemented mosquito nets.

HIVIAIDS: improve prevention by increasing the social marketing of condoms to an annual level of at least Implemented 10 million.

Sources: C.A.R. authorities; and World Bank and IMF staff assessments. 


\section{ECONOMiC OUTLOOK AND Program for 2009}

\section{A. Macroeconomic Outlook}

11. The global slowdown is jeopardizing C.A.R.'s short-term growth prospects. The chances that external demand will recover quickly are limited (see Box), and domestic supply is constrained by infrastructure bottlenecks and security concerns. Real GDP growth is projected to recover only to 2.4 percent in 2009 (Figure 7), but average CPI inflation should fall to about $43 / 4$ percent with stable food prices.

\section{Box 1. Impact of the Global Slowdown on Forestry in C.A.R.}

Forestry worldwide has experienced an abrupt decline in demand. Large inventories of unsold wood products limit prospects for a reversal.

For C.A.R., timber accounts for about 6 percent of GDP and half of goods exports. Because of low foreign demand and prices, since the last quarter of 2008 some firms have closed temporarily and most laid off workers. Forestry fiscal revenue declined by 7.2 percent in 2008 (see figure) and will undoubtedly decline further in 2009 in part because the authorities adopted tax relief measures to avoid economic and social disruption.

Figure. Central African Republic: Tax Revenues from Forestry Sector

Revenues from the forestry sector dropped in November and December 2008.

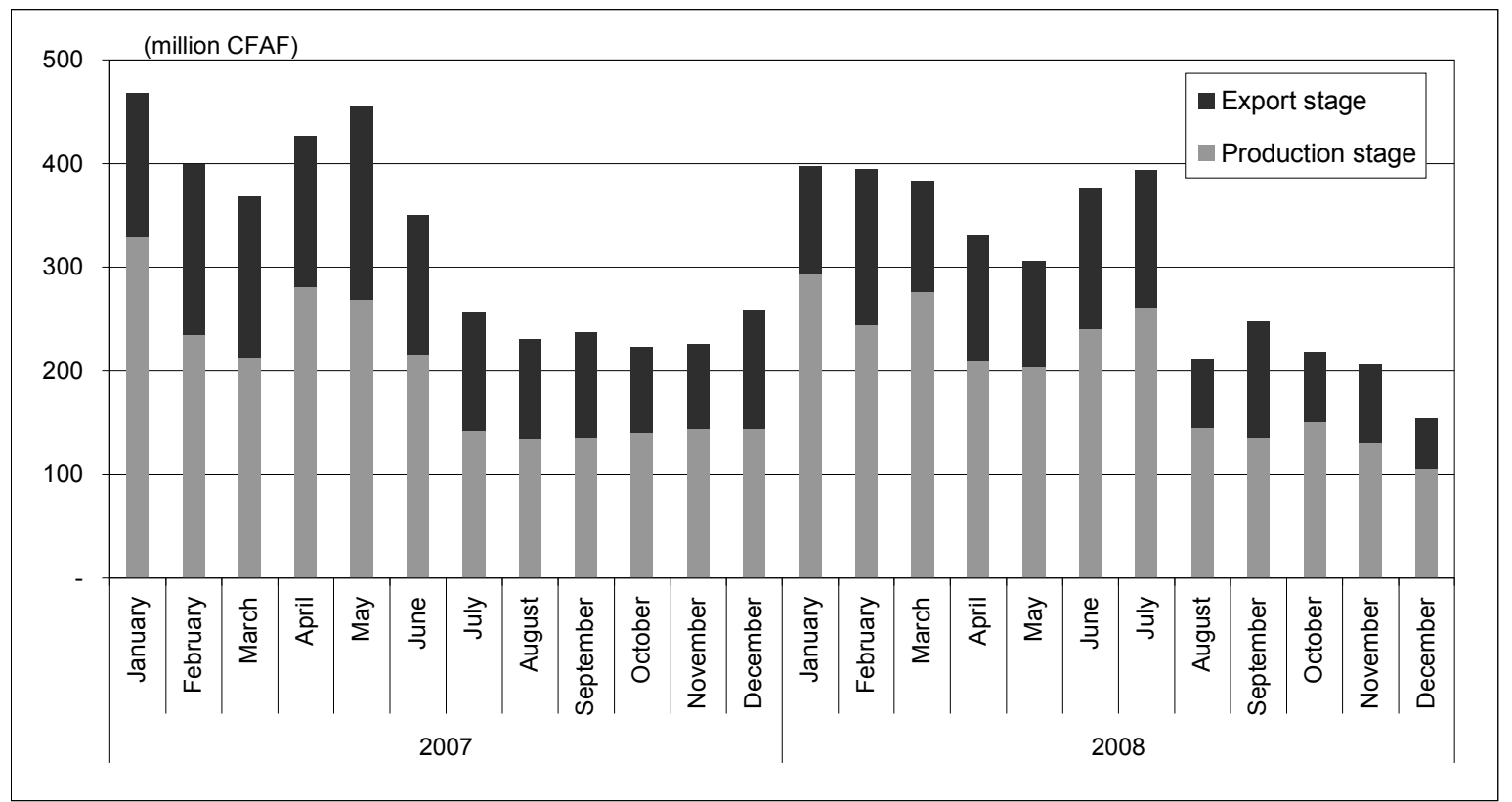

Sources: C.A.R. authorities; and IMF staff estimates.

12. Adverse external shocks are expected to erode official reserves in 2009. Despite significantly lower fuel imports, the trade deficit is projected to increase mainly because exports drop by 40 percent compared to program (4 percent of GDP). The trade deficit decline will not be fully offset by larger grants. Thus, the current account deficit will remain 
high at 10 percent of GDP. Moreover, private inflows will decline significantly as FDI is postponed; the resulting balance of payments deficit will require that C.A.R. draw down official foreign reserves to finance essential imports, reducing them from 3.3 months of imports at end-2008 to 2.6 months by year-end even if requested the augmentation of access is approved. The loss in NFA will reduce broad money, but credit to the private sector should expand faster than nominal GDP, reflecting some financial deepening.

Text Table 4. Central African Republic: Summary of External Shocks, 2008-09

The loss of reserves is mainly explained by trade developments (exports) and reduced private net flows, despite some additional donor budget support and increased access under the PRGF arrangement.

\begin{tabular}{lrrr}
\hline & 2008 & 2009 \\
\cline { 2 - 3 } & Est. & Prog. & Proj. (excl. HIPC) \\
\hline Current account & & (in billion CFAF) \\
$\quad$ Trade balance & -87.7 & -80.9 & -90.5 \\
$\quad$ Exports & -69.0 & -50.3 & -71.5 \\
$\quad$ Imports & 65.8 & 90.1 & 54.7 \\
Services and income (net) & -134.8 & -140.3 & -126.2 \\
Current transfers (net) & -52.8 & -58.4 & -57.9 \\
Capital account (net) & 34.1 & 27.7 & 38.9 \\
Financial account & 29.7 & 45.5 & 35.6 \\
$\quad$ Of which: private sector (mainly FDI) & 52.2 & 12.4 & 4.7 \\
Overall balance & 69.5 & 24.7 & 17.2 \\
Gross official foreign reserves without IMF augmentation ${ }^{1}$ & -5.9 & -23.0 & -33.5 \\
Gross official foreign reserves with IMF augmentation ${ }^{1}$ & 56.9 & 39.9 & 29.4 \\
\hline
\end{tabular}

Sources: C.A.R. authorities; and IMF staff projections.

${ }^{1}$ End of period.

\section{B. The 2009 Program}

\section{Fiscal framework}

13. Fiscal policy for the short run is designed to stabilize demand through government spending while preserving medium-term fiscal discipline; this is akin to allowing automatic stabilizers to work (though they are small) and requires a temporary relaxation of the primary domestic surplus. ${ }^{2}$ Fortunately, increased grant financing - partly intended to support peace building - allows for expanding spending relative to 2008 and relative to the program without more debt accumulating. The medium-term objective is still a domestic primary surplus of about 1 percent of GDP, which should limit any adverse impact on fiscal sustainability (Figure 7). Thus, the public debt-to-GDP ratio is projected to fall from 29.6 percent in 2009 to 25.6 percent in 2014 .

\footnotetext{
${ }^{2}$ The modification of the annual fiscal targets also required a modification of the end-June 2009 performance criteria.
} 
Figure 7. Central African Republic: Macroeconomic Framework, 2005-14

Growth recovers in the medium term ...

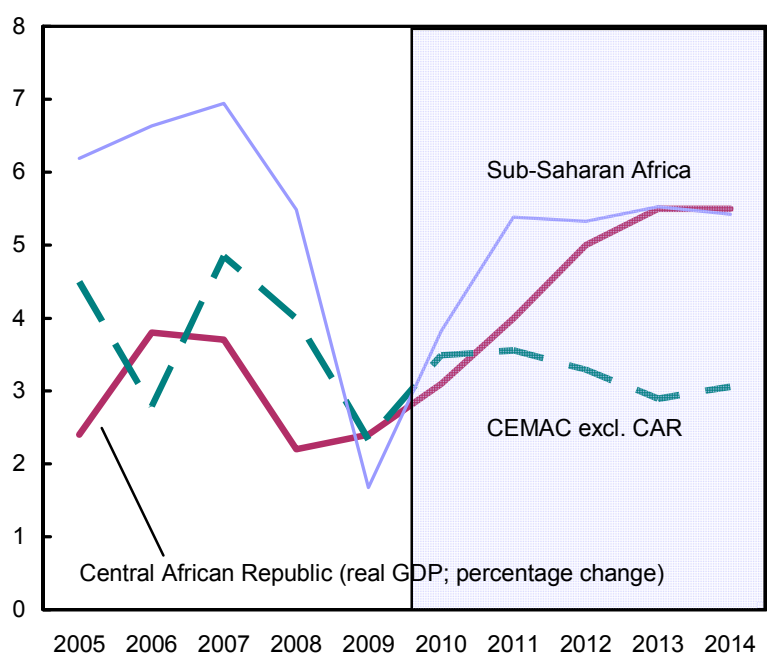

The current account balance improves slowly ...

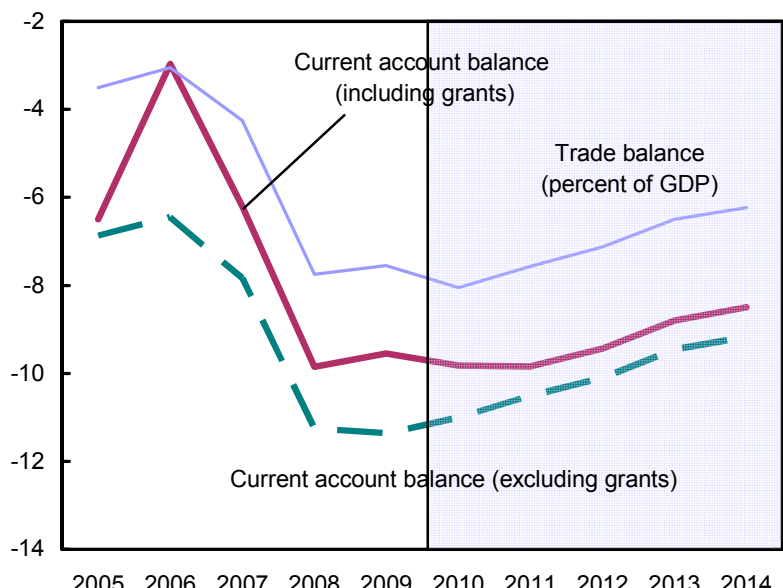

Domestic revenues rise slowly ...

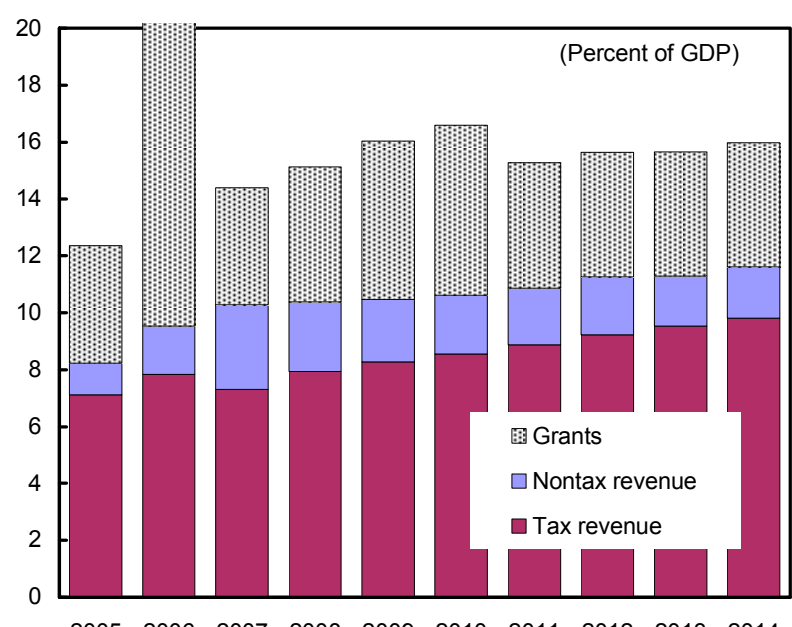

$20052006200720082009201020112012 \quad 20132014$
... and inflation moderates in line with CEMAC.

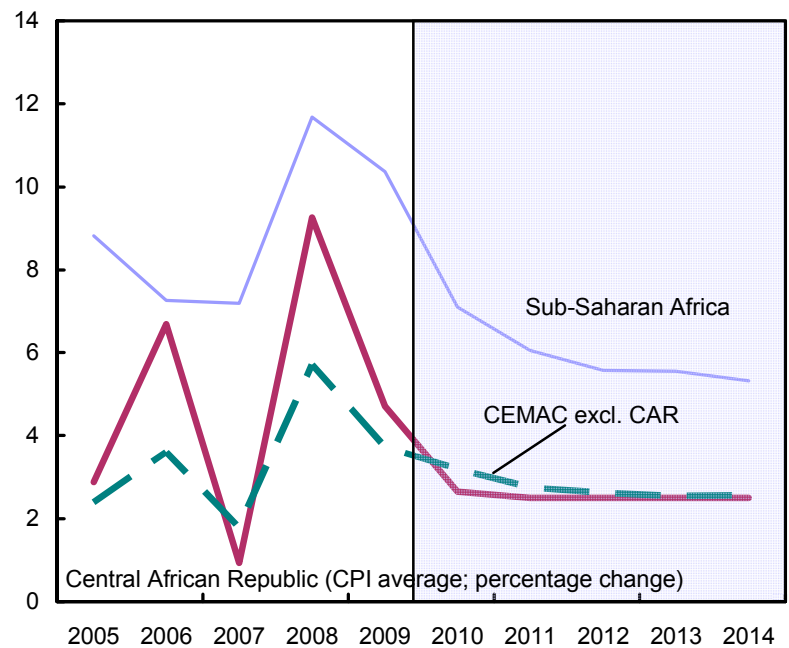

$\ldots$ and the prudent fiscal stance continues.

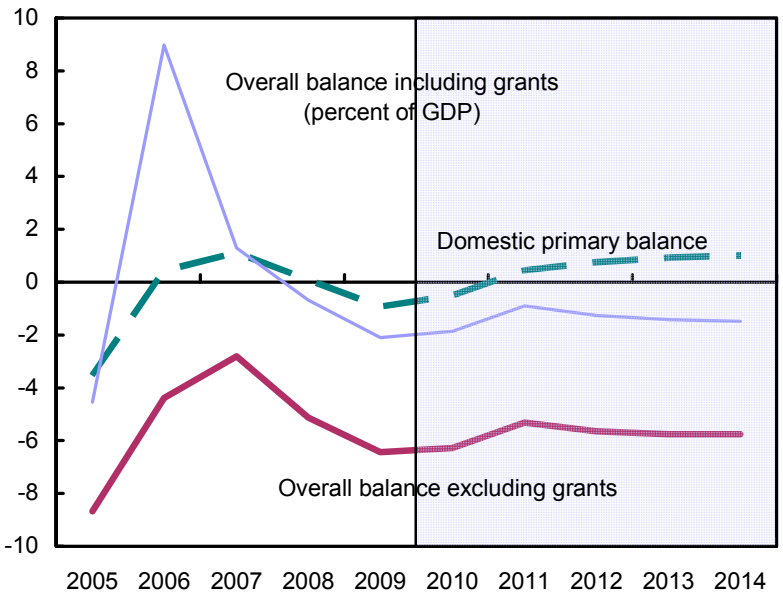

$\ldots$ and the share of capital expenditures grows.

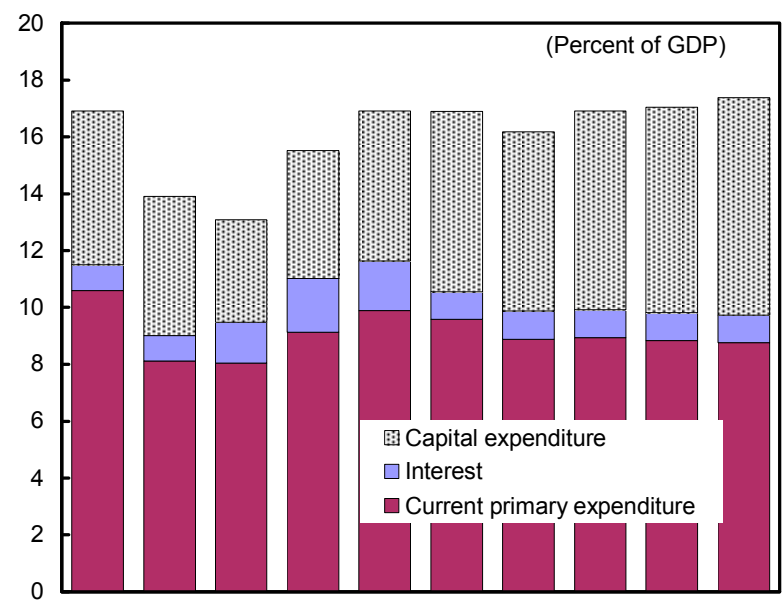

$20052006200720082009201020112012 \quad 2013 \quad 2014$

Sources: C.A.R. authorities; and IMF staff projections. 
14. Revenue declines by 0.7 percentage points of GDP relative to program as a result of the crisis. The main losses stem from a downward revision of the tax base for timber exports by some 30 percent in line with international prices (as foreseen by the formula), a delay in timber land rent payments, and expedited payment of VAT refund requests. More positively, the decision to increase fuel excises in 2008/09 is offsetting some crisis-related losses. Thus, with fuel taxes some 0.6 percent of GDP higher in 2009, the domestic revenue-to-GDP ratio still increases by 0.1 percentage points of GDP compared to 2008 (Text Table 5).

\section{The revised program protects budgeted priority spending and incorporates new} externally-financed spending on the peace process. The government should be able to fully execute the initial budget, which provides for unfreezing promotion-related salary increases from 1986-96, full payment of current government utility consumption, and a real increase in povertyreducing spending. A revised budget expected to be approved in July 2009 will incorporate additional spending of 1.1 percent of GDP on peace building (DDR), to be financed by the UN and CEMAC, and some spending to prepare for the 2010 elections.

Text Table 5. Central African Republic: Key Fiscal Variables and Program Revisions, 2008-09 (in percent of GDP)

\begin{tabular}{|c|c|c|c|}
\hline & \multirow{2}{*}{$\begin{array}{r}2008 \\
\text { Est. }\end{array}$} & \multicolumn{2}{|c|}{2009} \\
\hline & & Prog. & Proj. (excl. HIPC) \\
\hline Total revenue, of which: & 15.1 & 16.6 & 16.0 \\
\hline Domestic revenue & 10.4 & 11.2 & 10.5 \\
\hline Program grants & 1.4 & 0.6 & 1.8 \\
\hline Project grants & 3.3 & 4.7 & 3.8 \\
\hline Total expenditure, of which: & -15.5 & -16.9 & -16.9 \\
\hline Wages and salaries & -4.1 & -4.1 & -4.4 \\
\hline Transfers and subsidies ${ }^{1}$ & -2.5 & -1.9 & -2.6 \\
\hline Goods and services ${ }^{1}$ & -2.5 & -3.0 & -2.9 \\
\hline Domestic primary balance ${ }^{2}$ & 0.1 & 0.7 & -0.9 \\
\hline Change in arrears (- =reduction) & -1.2 & -1.6 & -1.1 \\
\hline Overall balance (cash basis) & -1.6 & -1.9 & -1.9 \\
\hline \multicolumn{4}{|l|}{ Memorandum item: } \\
\hline Spending for DDR ${ }^{1}$ & 0.0 & 0.0 & -1.1 \\
\hline
\end{tabular}

Sources: C.A.R. authorities; and IMF staff projections.

${ }^{1}$ Expenditure for Disarmament, Demobilization, and Reintegration (DDR) is estimated to consist mainly of transfers (0.9 percent of GDP) and limited spending on goods and services ( 0.2 percent of GDP).

${ }^{2}$ Excluding DDR expenditure, the 2009 domestic primary balance would deteriorate by 0.5 percentage points of GDP compared to the program reflecting lower domestic revenue.

\section{The decrease in the domestic primary surplus is being financed primarily by} additional grants. Compared to the program, domestic revenues decline by 0.7 percent of GDP, and domestic primary expenditures increase by 0.8 percent, mainly to finance the peace process (Text Table 5). Thus, the domestic primary surplus was lowered by 1.6 percentage points to a deficit of 0.9 percent of GDP, which is being financed mainly by higher program grants 
17. (1.2 percent of GDP) and some additional domestic financing. ${ }^{3}$ With financing sources limited and the need to reduce extremely costly domestic bank financing, clearance of domestic arrears was reduced somewhat but still represents 1 percent of GDP. Reaching the HIPC completion point would provide certainty in external debt service - thus allowing the authorities to redirect resources to priority spending. It would have little impact on the 2009 program given that interim debt relief had already been included in flow terms. The overall fiscal cash balance excluding HIPC Initiative and MDRI debt relief is unchanged from the program target, so that the revised fiscal stance in 2009 should not undermine debt sustainability.

\section{C.A.R.'s debt would become more manageable after reaching the HIPC completion} point. The updated debt sustainability analysis (DSA) using the low-income country (LIC) framework shows that external and public debt burden indicators would improve significantly thanks to debt relief under the enhanced HIPC Initiative and the Multilateral Debt Relief Initiative (MDRI) (see Figure 8). ${ }^{4}$ This is the case even after incorporating the proposed augmentation of access under the PRGF arrangement and projected financing from all other sources. C.A.R.'s rating of the risk for debt distress would be moderate; implying that it continues to be vulnerable to certain shocks, especially growth and export shocks.

\section{Structural reforms}

\section{Structural reforms are designed to support economic stability and the recovery of} growth. Building on progress already achieved, future measures are intended to further strengthen fiscal management capacity and will emphasize revenue generation, PFM, public enterprise reforms, in addition to structural reforms that support private sector activity.

20. Revenue collection is at the center of fiscal reform efforts. Despite recent gains, the domestic revenue ratio is still one of the lowest in sub-Saharan Africa. Further reforms will interconnect tax and customs department computer systems (end-June 2009 SB) and reduce customs exemptions (end-2009 SB). The new tax audit unit should expand risk-based tools for detecting fraud and direct audits to the largest revenue risks. The authorities also intend to undertake comprehensive tax policy reform in 2010 for implementation in 2011 (MEFP |27).

\footnotetext{
${ }^{3}$ The CEMAC support consists of a CFAF 1 billion grant from each of the five other CEMAC members (two have paid already) and a CFAF 3 billion loan from the BEAC.

${ }^{4}$ The LIC-DSA is included in the Appendix II of the HIPC Completion Point document, which is scheduled to be discussed concurrently with this staff report.
} 
Figure 8. Central African Republic: Indicators of Public Debt Under Alternative Scenarios, 2009-29 ${ }^{1}$
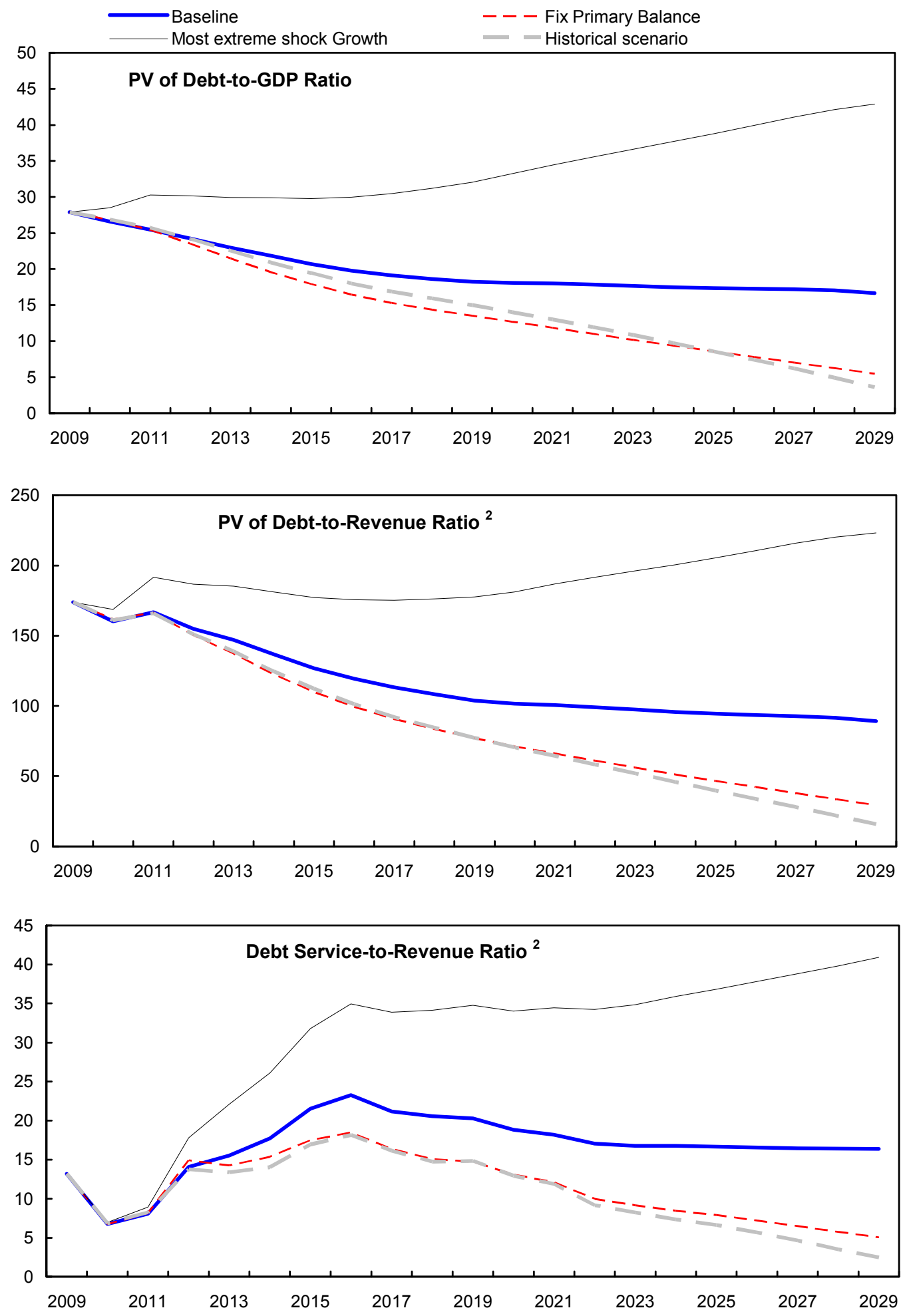

Sources: C.A.R. authorities; and Fund staff estimates and projections.

' Assumes HIPC and MDRI debt relief. The most extreme stress test is the test that yields the highest ratio in 2019.

${ }^{2}$ Revenues are defined inclusive of grants. 
21. PFM is being built up. Gesco, the GFMIS, already covers the expenditure chain from commitments to payment authorization and is being extended to payments (end-2009 SB). Nonstandard expenditure procedures will be contained and promptly recorded in Gesco. The authorities have closed most commercial bank accounts except those that are donor-mandated. Operating the remaining accounts on a zero balance basis requires more technical work, thus delaying the treasury single account (TSA, end-2009 SB, MEFP q28). Because legal revisions related to government guarantees will be handled as part of the revised 2009 budget, there will be a minor delay to end-September (SB). Regarding debt management, once standard external and internal debt contracts are integrated into the debt database, all domestic arrears will also be integrated (end-2009 SB).

22. The authorities are moving to reduce public enterprise losses and facilitate private sector development. To clarify financial relations between public enterprises and the government, the program explicitly targets improvement in the financial performance of the utility companies and reduction of cross-payment arrears to help alleviate infrastructure bottlenecks, which are crippling growth prospects. The new mining and forestry codes should help attract FDI and bring other economic benefits. Firm enforcement and stable regulation will also be vital to stimulating private investment.

\section{Program Access, Financing, And Monitoring}

23. The request for augmentation is justified by balance of payments needs and a solid reform program. Export demand and FDI have collapsed - to the detriment of official reserves - but should recover over the medium term. Despite limited administrative capacity the authorities are implementing an ambitious reform program. The requested augmentation would align access with the new 125 percent of quota norm for second-time PRGF users and help C.A.R. adjust to the external shocks. The medium-term balance of payments position is expected to improve, mainly because of fiscal efforts and structural reforms to reduce bottlenecks in electricity and water supply.

24. The fifth and sixth PRGF reviews will be based on test dates for end-June and endDecember 2009. The authorities ask that the PRGF arrangement be extended until June 30, 2010 to allow the last two reviews to take place on a six-month interval. Quantitative and structural conditionality are defined in Tables 1 and 2 of the MEFP. The program is fully financed in 2009.

\section{Staff Appraisal}

25. C.A.R.'s resilience to economic shocks strengthened under the PRGF arrangement. Fiscal management has become more credible through prudent budget execution, particularly regular wage payments and clearance of arrears. Thanks to the politically difficult decision to raise fuel excises several times, the government now collects significant revenues from petroleum consumption, cushioning crisis-related revenue losses.

\section{Building on recent reforms, C.A.R. should firm up fiscal management and support} private activity. The government should emphasize capacity to raise revenues, control and 
27. Improving security and preserving political stability are imperative for accelerating growth and reducing poverty - the highest priority in the PRSP. The authorities should secure additional donor assistance for the DDR and the 2010 elections. Keeping the economy stable, which is indispensable for political stability, is a challenge in the difficult global environment, but steadfast implementation of the agreed policies should help.

28. Continued and timely donor support is essential. Despite C.A.R.'s efforts, its resources and capacity are limited. DDR funding requires external assistance. The forthcoming HIPC and MDRI assistance helps to provide much needed fiscal space for priority spending, but projected aid and domestic resources are not sufficient for achieving the Millennium

Development Goals. Although confidence in fiscal management has improved and the economy is more resilient to shocks, the budget cannot fully absorb the current shock.

29. Coordination with C.A.R.'s development partners will be crucial. Continued highly concessional financing and technical assistance are necessary; aid should be more predictable and technical assistance harmonized, given the authorities' limited capacity. In this context, the government needs to more effectively communicate its own reform efforts. C.A.R. is engaged in good faith efforts to reach collaborative agreements with external private creditors and relations with those creditors have not undermined program implementation.

30. The main risks to the program are a prolonged slump in economic activities or political instability. Delays in the recovery of key export sectors - either due to worsening of global demand conditions or investor concerns - could undermine economic stability. The success of the program also depends on political stability, which hinges critically on implementation of the peace building process and availability of its financing. Continuous implementation of the automatic petroleum pricing formula would be important if world oil prices become volatile again.

31. Staff supports completion of the fourth review, augmentation of access under the PRGF arrangement, and extension of the PRGF arrangement. Implementation of the program has been broadly satisfactory in a difficult political and economic environment. Staff also supports a waiver for the PC on commercial bank credit (minor deviation). Augmentation of access will limit reserve losses and help C.A.R. adjust to current external shocks. Staff also supports the modification of quantitative PCs for end-June 2009, and the conversion of the continuous structural PC on automatic fuel price adjustment mechanism into a structural benchmark. 
Table 1. Central African Republic: Selected Economic and Financial Indicators, 2005-14 ${ }^{1}$

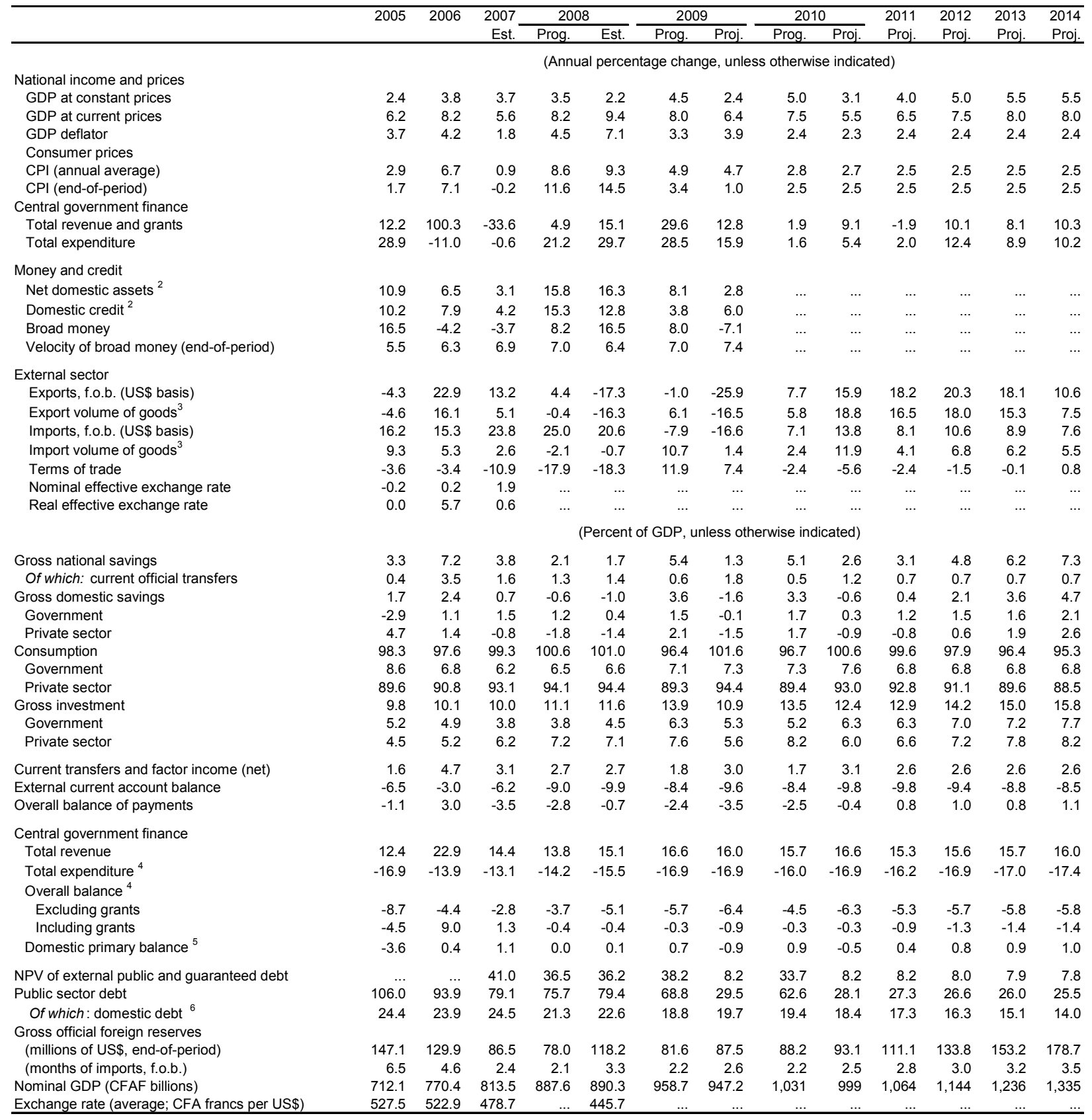

Sources: C.A.R. authorities; and IMF staff estimates and projections.

${ }^{1}$ The macroeconomic framework assumes that the C.A.R. reaches the HIPC completion point in 2009;

the balance of payments projections incorporate debt relief expected to be delivered at the completion point.

${ }^{2}$ Percent of broad money at beginning of the period.

${ }^{3}$ Historical volume data were recalculated using a new methodology. For comparability purposes, the program numbers for 2008-10 were also recalculated.

${ }^{4}$ Expenditures are on a cash basis for current period expenditures.

${ }^{5}$ Excludes grants, interest payments, and externally financed capital expenditure.

${ }^{6}$ Comprises government debt to BEAC and commercial banks, government arrears and public enterprises' domestic debt. 
Table 2. Central African Republic: Central Government Operations, 2005-14 ${ }^{1}$

(CFAF billions)

\begin{tabular}{|c|c|c|c|c|c|c|c|c|c|c|c|c|c|c|}
\hline & \multirow[t]{2}{*}{2005} & \multirow[t]{2}{*}{2006} & \multirow{2}{*}{$\begin{array}{r}2007 \\
\text { Est. }\end{array}$} & \multicolumn{2}{|c|}{2008} & \multicolumn{3}{|c|}{2009} & \multicolumn{2}{|c|}{2010} & \multirow{2}{*}{$\begin{array}{l}2011 \\
\text { Proj. }\end{array}$} & \multirow{2}{*}{$\begin{array}{r}2012 \\
\text { Proj. }\end{array}$} & \multirow{2}{*}{$\begin{array}{c}2013 \\
\text { Proj. }\end{array}$} & \multirow{2}{*}{$\begin{array}{l}2014 \\
\text { Proj. }\end{array}$} \\
\hline & & & & Prog. & Est. & Prog. & $\begin{array}{l}\text { Proj. } \\
\text { cl. HIPC }\end{array}$ & Proj. & Prog. & Proj. & & & & \\
\hline Revenue & 88.0 & 176.3 & 117.0 & 122.8 & 134.7 & 159.1 & 151.9 & 544.9 & 162.1 & 165.8 & 162.6 & 179.0 & 193.4 & 213.3 \\
\hline Domestic revenue & 58.6 & 73.4 & 83.6 & 93.8 & 92.5 & 107.8 & 99.1 & 99.1 & 118.8 & 106.1 & 115.6 & 128.8 & 139.5 & 155.1 \\
\hline Tax revenue & 50.6 & 60.4 & 59.5 & 70.3 & 70.7 & 85.4 & 78.3 & 78.3 & 96.2 & 85.5 & 94.3 & 105.6 & 117.8 & 130.9 \\
\hline Taxes on profits and property & 14.7 & 17.5 & 14.4 & 17.3 & 14.6 & 18.7 & 14.9 & 14.9 & 20.8 & 16.2 & 18.4 & 20.7 & 23.1 & 25.8 \\
\hline Taxes on goods and services & 35.9 & 42.9 & 45.1 & 53.0 & 56.0 & 66.7 & 63.4 & 63.4 & 75.3 & 69.2 & 76.0 & 84.9 & 94.7 & 105.1 \\
\hline Of which: taxes on international trade & 9.5 & 15.3 & 14.5 & 16.8 & 16.5 & 21.7 & 18.6 & 18.6 & 24.0 & 19.8 & 22.0 & 24.6 & 27.4 & 30.5 \\
\hline Nontax revenue & 8.0 & 12.9 & 24.1 & 23.5 & 21.8 & 22.5 & 20.8 & 20.8 & 22.6 & 20.6 & 21.2 & 23.2 & 21.7 & 24.1 \\
\hline Grants & 29.5 & 102.9 & 33.4 & 28.9 & 42.2 & 51.2 & 52.8 & 445.8 & 43.3 & 59.7 & 47.0 & 50.1 & 53.9 & 58.3 \\
\hline Program & 2.7 & 75.7 & 13.2 & 11.9 & 12.6 & 5.7 & 17.2 & 17.2 & 5.0 & 11.8 & 7.0 & 7.6 & 8.2 & 8.8 \\
\hline Debt forgiveness & $\cdots$ & $\cdots$ & $\cdots$ & $\ldots$ & $\cdots$ & $\ldots$ & $\cdots$ & 376.3 & $\ldots$ & $\ldots$ & $\cdots$ & $\ldots$ & $\ldots$ & $\ldots$ \\
\hline MDRI grants from IMF & $\ldots$ & $\ldots$ & $\ldots$ & $\ldots$ & $\ldots$ & $\ldots$ & $\ldots$ & 16.7 & $\ldots$ & $\ldots$ & $\ldots$ & $\ldots$ & $\ldots$ & $\ldots$ \\
\hline Project & 26.7 & 27.2 & 20.2 & 17.0 & 29.7 & 45.5 & 35.6 & 35.6 & 38.3 & 47.9 & 40.0 & 42.6 & 45.8 & 49.4 \\
\hline Expenditure $^{<}$ & -120.4 & -107.2 & -106.5 & -126.4 & -138.1 & -162.4 & -160.1 & -160.1 & -165.0 & -168.8 & -172.2 & -193.5 & -210.7 & -232.1 \\
\hline Current primary expenditure & -75.4 & -62.5 & -65.4 & -77.9 & -81.4 & -86.8 & -93.6 & -93.6 & -94.4 & -95.7 & -94.4 & -102.2 & -109.1 & -116.9 \\
\hline Wages and salaries & -39.2 & -37.2 & -36.3 & -37.5 & -36.9 & -39.6 & -41.8 & -41.8 & -44.6 & -44.1 & -47.0 & -50.5 & -54.5 & -58.9 \\
\hline Transfers and subsidies & -14.0 & -10.2 & -14.7 & -20.5 & -22.4 & -18.7 & -24.7 & -24.7 & -19.1 & -19.4 & -22.2 & -24.5 & -25.3 & -26.0 \\
\hline Goods and Services ${ }^{3}$ & -22.2 & -15.2 & -14.4 & -19.9 & -22.0 & -28.5 & -27.1 & -27.1 & -30.7 & -32.1 & -25.2 & -27.1 & -29.3 & -32.0 \\
\hline Interest due & -6.6 & -6.9 & -11.7 & -14.4 & -16.7 & -15.6 & -16.7 & -16.7 & -16.8 & -9.8 & -10.7 & -11.3 & -12.2 & -13.0 \\
\hline External & -3.6 & -4.2 & -3.7 & -9.0 & -9.1 & -9.1 & -9.8 & -9.8 & -9.5 & -2.4 & -2.4 & -2.3 & -2.2 & -2.2 \\
\hline Domestic & -3.0 & -2.7 & -8.0 & -5.4 & -7.7 & -6.5 & -6.9 & -6.9 & -7.3 & -7.4 & -8.3 & -9.0 & -10.0 & -10.8 \\
\hline Capital expenditure & -38.4 & -37.7 & -29.4 & -34.1 & -40.0 & -60.0 & -49.8 & -49.8 & -53.9 & -63.4 & -67.1 & -80.0 & -89.4 & -102.2 \\
\hline Domestically financed & -8.4 & -7.5 & -9.2 & -16.1 & -10.4 & -14.5 & -14.2 & -14.2 & -15.5 & -15.5 & -16.5 & -18.0 & -18.9 & -24.7 \\
\hline Externally financed & -29.9 & -30.2 & -20.2 & -18.0 & -29.7 & -45.5 & -35.6 & -35.6 & -38.3 & -47.9 & -50.6 & -62.0 & -70.5 & -77.5 \\
\hline \multicolumn{15}{|l|}{ Overall balance ${ }^{3}$} \\
\hline Excluding grants & -61.8 & -33.8 & -22.9 & -32.6 & -45.7 & -54.6 & -61.0 & -61.0 & -46.2 & -62.8 & -56.6 & -64.7 & -71.2 & -77.0 \\
\hline Of which: domestic primary balance ${ }^{4}$ & -25.3 & 3.3 & 9.0 & -0.2 & 0.7 & 6.6 & -8.7 & -8.7 & 8.9 & -5.1 & 4.7 & 8.6 & 11.5 & 13.4 \\
\hline Including grants & -32.4 & 69.1 & 10.6 & -3.7 & -3.5 & -3.3 & -8.2 & 384.8 & -2.9 & -3.1 & -9.6 & -14.5 & -17.2 & -18.7 \\
\hline Change in arrears (net; $(-)=$ reduction) & 26.9 & -60.3 & -16.1 & -10.0 & -10.5 & -15.0 & -10.0 & -10.0 & -15.0 & -15.0 & -15.0 & -15.0 & -15.0 & -15.0 \\
\hline Domestic & 9.4 & -19.8 & -13.7 & -10.0 & -10.5 & -15.0 & -10.0 & -10.0 & -15.0 & -15.0 & -15.0 & -15.0 & -15.0 & -15.0 \\
\hline External $^{\mathrm{b}}$ & 17.5 & -40.5 & -2.4 & 0.0 & 0.0 & 0.0 & 0.0 & 0.0 & 0.0 & 0.0 & 0.0 & 0.0 & 0.0 & 0.0 \\
\hline Overall balance, cash basis & -5.5 & 8.8 & -5.5 & -13.7 & -14.0 & -18.3 & -18.2 & 374.8 & -17.9 & -18.1 & -24.6 & -29.5 & -32.2 & -33.7 \\
\hline Identified financing & 5.5 & -3.8 & 1.0 & 17.7 & 19.4 & 18.3 & 4.6 & -388.4 & 17.9 & 13.9 & 24.7 & 29.5 & 32.3 & 33.7 \\
\hline External, net & -4.5 & -12.9 & -9.5 & 6.8 & 5.8 & 7.9 & 7.9 & -368.4 & 4.5 & -1.5 & 9.1 & 11.5 & 16.7 & 19.8 \\
\hline Project loans & 3.2 & 3.0 & 0.0 & 1.0 & 0.0 & 0.0 & 0.0 & 0.0 & 0.0 & 0.0 & 10.6 & 19.4 & 24.7 & 28.0 \\
\hline Program loans & 4.0 & 0.0 & 0.0 & 0.0 & 0.0 & 0.0 & 0.0 & 0.0 & 0.0 & 0.0 & 0.0 & 0.0 & 0.0 & 0.0 \\
\hline Amortization due & -11.8 & -15.9 & -12.4 & -11.2 & -11.3 & -12.3 & -12.6 & -388.9 & -25.9 & -1.5 & -1.6 & -7.9 & -8.1 & -8.2 \\
\hline Exceptional financing & 0.0 & 0.0 & 2.9 & 17.0 & 17.1 & 20.2 & 20.5 & 20.5 & 30.4 & 0.0 & 0.0 & 0.0 & 0.0 & 0.0 \\
\hline Paris Club ${ }^{6}$ & 0.0 & 0.0 & 1.5 & 1.0 & 1.0 & 1.1 & 1.1 & 1.1 & 1.4 & 0.0 & 0.0 & 0.0 & 0.0 & 0.0 \\
\hline Other $^{7}$ & 0.0 & 0.0 & 1.4 & 16.1 & 16.1 & 19.1 & 19.4 & 19.4 & 29.0 & 0.0 & 0.0 & 0.0 & 0.0 & 0.0 \\
\hline Domestic, net & 10.0 & 9.1 & 10.5 & 10.9 & 13.6 & 10.4 & -3.3 & -20.0 & 13.4 & 15.4 & 15.6 & 18.0 & 15.6 & 13.9 \\
\hline Banking system & 10.0 & 4.1 & 10.0 & 11.4 & 9.0 & 0.5 & 6.8 & -9.9 & -5.4 & 2.3 & -3.6 & -6.3 & -6.4 & -8.4 \\
\hline Counterpart to IMF resources (BEAC) & -2.6 & 2.2 & 2.4 & 6.8 & 5.2 & 4.4 & 3.8 & -12.9 & -1.2 & 2.3 & 0.0 & 0.0 & 0.0 & -1.5 \\
\hline Central Bank & 10.2 & -2.3 & 6.6 & -1.3 & -3.0 & -4.3 & 9.0 & 9.0 & 0.0 & 0.0 & -0.9 & -3.5 & -3.6 & -4.1 \\
\hline Commercial banks & 2.4 & 4.2 & 1.0 & 5.8 & 6.9 & 0.4 & -6.0 & -6.0 & -4.2 & 0.0 & -2.8 & -2.8 & -2.8 & -2.8 \\
\hline Of which: bonds & $\ldots$ & $\ldots$ & $\ldots$ & 0.0 & 0.0 & 21.0 & 0.0 & 0.0 & -4.2 & 13.9 & -2.8 & -2.8 & -2.8 & -2.8 \\
\hline Nonbank $^{8}$ & 0.0 & 5.0 & 0.5 & -0.5 & 4.6 & 9.9 & -10.1 & -10.1 & 18.8 & 13.1 & 19.2 & 24.2 & 22.0 & 22.3 \\
\hline Errors and omissions & 0.0 & 5.0 & -4.5 & 4.0 & 5.5 & 0.0 & 0.9 & 0.9 & 0.0 & 0.0 & 0.0 & 0.0 & 0.0 & 0.0 \\
\hline Residual financing need ${ }^{9}$ & 0.0 & 0.0 & 0.0 & 0.0 & 0.0 & 0.0 & 14.5 & 14.5 & 0.0 & 4.1 & 0.0 & 0.0 & 0.0 & 0.0 \\
\hline \multicolumn{15}{|l|}{ Memorandum items: } \\
\hline Government domestic debt & 173.4 & 183.9 & 199.2 & 188.9 & 201.5 & 180.2 & 186.7 & 186.7 & 199.8 & 183.4 & 183.7 & 186.4 & 186.8 & 187.4 \\
\hline Of which: domestic arrears & 109.7 & 109.7 & 114.7 & 104.7 & 104.2 & 89.7 & 94.2 & 94.2 & 74.7 & 79.2 & 64.2 & 49.2 & 34.2 & 19.2 \\
\hline Spending for DDR & & & & & & & 10.0 & 10.0 & & & $\cdots$ & $\ldots$ & $\ldots$ & $\ldots$ \\
\hline Nominal GDP & 712.1 & 770.4 & 813.5 & 887.6 & 890.3 & 958.7 & 947.2 & 947.2 & 1,031 & 999 & 1,064 & 1,144 & 1,236 & 1,335 \\
\hline
\end{tabular}

Sources: C.A.R. authorities; and IMF staff estimates and projections.

${ }^{1}$ The new classification starts in 2007. It affects mainly revenues. Some fees previously recorded as taxes are now included as nontax revenue.

${ }^{2}$ Expenditures are on a cash basis for current period expenditures, except for interest, which is recorded on a due-basis.

${ }^{3}$ In 2009, includes outlays for the peace process (DDR), of which 80 percent are allocated to transfers and 20 percent to goods and services.

${ }^{4}$ Excludes grants, interest payments, and externally financed capital expenditure.

${ }^{5}$ Figure for 2006 reflects arrears clearance by the World Bank and the AfDB (CFAF 47.5 billion) and the increase in arrears to bilateral and a few multilateral creditors (CFAF 6.9 billion).

${ }^{6}$ Reflects Paris Club rescheduling and moratorium agreement in April 2007.

${ }^{7}$ Includes HIPC debt relief from multilateral and other bilateral creditors. For 2008-09, also includes debt service to non-Paris Club and commercial creditors.

For 2010 onward, reflects full delivery of HIPC and MDRI relief on a flow basis.

${ }^{8}$ Includes loan covenants signed with commercial banks domiciliated in CEMAC countries, debt with oil suppliers, and expected future bond issues.

${ }^{9}$ The gaps in 2009 and 2010 projections are equivalent to the proposed augmentation of PRGF access. 
Table 3. Central African Republic: Central Government Operations, 2005-14 ${ }^{1}$

\begin{tabular}{|c|c|c|c|c|c|c|c|c|c|c|c|c|c|c|}
\hline \multirow{3}{*}{ 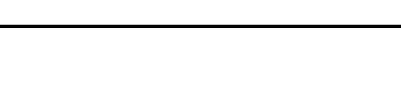 } & \multirow{3}{*}{2005} & \multirow{3}{*}{2006} & \multirow{3}{*}{$\begin{array}{r}2007 \\
\text { Est. }\end{array}$} & \multicolumn{5}{|c|}{ (Percent of GDP) } & \multirow{2}{*}{\multicolumn{2}{|c|}{2010}} & \multirow{3}{*}{$\begin{array}{l}2011 \\
\text { Proj. }\end{array}$} & \multirow{3}{*}{$\begin{array}{l}2012 \\
\text { Proj. }\end{array}$} & \multirow{3}{*}{$\begin{array}{l}2013 \\
\text { Proj. }\end{array}$} & \multirow{3}{*}{$\begin{array}{l}2014 \\
\text { Proj. }\end{array}$} \\
\hline & & & & \multicolumn{2}{|c|}{2008} & \multicolumn{3}{|c|}{2009} & & & & & & \\
\hline & & & & Prog. & Est. & Prog. & $\begin{array}{l}\text { Proj. } \\
\text { HIPC }\end{array}$ & Proj. & Prog. & Proj. & & & & \\
\hline & 12.4 & 22.9 & 14.4 & 13.8 & 15.1 & 16.6 & 16.0 & 57.5 & 15.7 & 16.6 & 15.3 & 15.6 & 15.7 & 16.0 \\
\hline Domestic revenue & 8.2 & 9.5 & 10.3 & 10.6 & 10.4 & 11.2 & 10.5 & 10.5 & 11.5 & 10.6 & 10.9 & 11.3 & 11.3 & 11.6 \\
\hline Tax revenue & 7.1 & 7.8 & 7.3 & 7.9 & 7.9 & 8.9 & 8.3 & 8.3 & 9.3 & 8.6 & 8.9 & 9.2 & 9.5 & 9.8 \\
\hline Taxes on profits and property & 2.1 & 2.3 & 1.8 & 1.9 & 1.6 & 1.9 & 1.6 & 1.6 & 2.0 & 1.6 & 1.7 & 1.8 & 1.9 & 1.9 \\
\hline Taxes on goods and services & 5.0 & 5.6 & 5.5 & 6.0 & 6.3 & 7.0 & 6.7 & 6.7 & 7.3 & 6.9 & 7.1 & 7.4 & 7.7 & 7.9 \\
\hline Of which: taxes on international trade & 1.3 & 2.0 & 1.8 & 1.9 & 1.9 & 2.3 & 2.0 & 2.0 & 2.3 & 2.0 & 2.1 & 2.1 & 2.2 & 2.3 \\
\hline Nontax revenue & 1.1 & 1.7 & 3.0 & 2.6 & 2.4 & 2.3 & 2.2 & 2.2 & 2.2 & 2.1 & 2.0 & 2.0 & 1.8 & 1.8 \\
\hline Grants & 4.1 & 13.4 & 4.1 & 3.3 & 4.7 & 5.3 & 5.6 & 47.1 & 4.2 & 6.0 & 4.4 & 4.4 & 4.4 & 4.4 \\
\hline Program & 0.4 & 9.8 & 1.6 & 1.3 & 1.4 & 0.6 & 1.8 & 1.8 & 0.5 & 1.2 & 0.7 & 0.7 & 0.7 & 0.7 \\
\hline Debt forgiveness & $\ldots$ & $\ldots$ & $\ldots$ & $\ldots$ & $\ldots$ & $\ldots$ & $\ldots$ & 39.7 & $\ldots$ & $\ldots$ & $\ldots$ & $\ldots$ & $\ldots$ & \\
\hline MDRI grants from IMF & & $\ldots$ & & - & $\ldots$ & & $\ldots$ & 1.8 & & & & & & \\
\hline Project & 3.8 & 3.5 & 2.5 & 1.9 & 3.3 & 4.7 & 3.8 & 3.8 & 3.7 & 4.8 & 3.8 & 3.7 & 3.7 & 3.7 \\
\hline Expenditure $^{2}$ & -16.9 & -13.9 & -13.1 & -14.2 & -15.5 & -16.9 & -16.9 & -16.9 & -16.0 & -16.9 & -16.2 & -16.9 & -17.0 & -17.4 \\
\hline Current primary expenditure & -10.6 & -8.1 & -8.0 & -8.8 & -9.1 & -9.1 & -9.9 & -9.9 & -9.2 & -9.6 & -8.9 & -8.9 & -8.8 & -8.8 \\
\hline Wages and salaries & -5.5 & -4.8 & -4.5 & -4.2 & -4.1 & -4.1 & -4.4 & -4.4 & -4.3 & -4.4 & -4.4 & -4.4 & -4.4 & -4.4 \\
\hline Transfers and subsidies & -2.0 & -1.3 & -1.8 & -2.3 & -2.5 & -1.9 & -2.6 & -2.6 & -1.9 & -1.9 & -2.1 & -2.1 & -2.0 & -1.9 \\
\hline Goods and Services ${ }^{3}$ & -3.1 & -2.0 & -1.8 & -2.2 & -2.5 & -3.0 & -2.9 & -2.9 & -3.0 & -3.2 & -2.4 & -2.4 & -2.4 & -2.4 \\
\hline Interest due & -0.9 & -0.9 & -1.4 & -1.6 & -1.9 & -1.6 & -1.8 & -1.8 & -1.6 & -1.0 & -1.0 & -1.0 & -1.0 & -1.0 \\
\hline External & -0.5 & -0.5 & -0.4 & -1.0 & -1.0 & -0.9 & -1.0 & -1.0 & -0.9 & -0.2 & -0.2 & -0.2 & -0.2 & -0.2 \\
\hline Domestic & -0.4 & -0.4 & -1.0 & -0.6 & -0.9 & -0.7 & -0.7 & -0.7 & -0.7 & -0.7 & -0.8 & -0.8 & -0.8 & -0.8 \\
\hline Capital expenditure & -5.4 & -4.9 & -3.6 & -3.8 & -4.5 & -6.3 & -5.3 & -5.3 & -5.2 & -6.3 & -6.3 & -7.0 & -7.2 & -7.7 \\
\hline Domestically financed & -1.2 & -1.0 & -1.1 & -1.8 & -1.2 & -1.5 & -1.5 & -1.5 & -1.5 & -1.6 & -1.6 & -1.6 & -1.5 & -1.9 \\
\hline Externally financed & -4.2 & -3.9 & -2.5 & -2.0 & -3.3 & -4.7 & -3.8 & -3.8 & -3.7 & -4.8 & -4.8 & -5.4 & -5.7 & -5.8 \\
\hline \multicolumn{15}{|l|}{ Overall balance $^{3}$} \\
\hline Excluding grants & -8.7 & -4.4 & -2.8 & -3.7 & -5.1 & -5.7 & -6.4 & -6.4 & -4.5 & -6.3 & -5.3 & -5.7 & -5.8 & -5.8 \\
\hline Of which: domestic primary balance ${ }^{4}$ & -3.6 & 0.4 & 1.1 & 0.0 & 0.1 & 0.7 & -0.9 & -0.9 & 0.9 & -0.5 & 0.4 & 0.8 & 0.9 & 1.0 \\
\hline Including grants & -4.5 & 9.0 & 1.3 & -0.4 & -0.4 & -0.3 & -0.9 & 40.6 & -0.3 & -0.3 & -0.9 & -1.3 & -1.4 & -1.4 \\
\hline Change in arrears (net; $(-)=$ reduction) & 3.8 & -7.8 & -2.0 & -1.1 & -1.2 & -1.6 & -1.1 & -1.1 & -1.5 & -1.5 & -1.4 & -1.3 & -1.2 & -1.1 \\
\hline Domestic & 1.3 & -2.6 & -1.7 & -1.1 & -1.2 & -1.6 & -1.1 & -1.1 & -1.5 & -1.5 & -1.4 & -1.3 & -1.2 & -1.1 \\
\hline External $^{5}$ & 2.5 & -5.3 & -0.3 & 0.0 & 0.0 & 0.0 & 0.0 & 0.0 & 0.0 & 0.0 & 0.0 & 0.0 & 0.0 & 0.0 \\
\hline Overall balance, cash basis & -0.8 & 1.1 & -0.7 & -1.5 & -1.6 & -1.9 & -1.9 & 39.6 & -1.7 & -1.8 & -2.3 & -2.6 & -2.6 & -2.5 \\
\hline Identified financing & 0.8 & -0.5 & 0.1 & 2.0 & 2.2 & 1.9 & 0.5 & -41.0 & 1.7 & 1.4 & 2.3 & 2.6 & 2.6 & 2.5 \\
\hline External, net & -0.6 & -1.7 & -1.2 & 0.8 & 0.7 & 0.8 & 0.8 & -38.9 & 0.4 & -0.1 & 0.9 & 1.0 & 1.3 & 1.5 \\
\hline Project loans & 0.5 & 0.4 & 0.0 & 0.1 & 0.0 & 0.0 & 0.0 & 0.0 & 0.0 & 0.0 & 1.0 & 1.7 & 2.0 & 2.1 \\
\hline Program loans & 0.6 & 0.0 & 0.0 & 0.0 & 0.0 & 0.0 & 0.0 & 0.0 & 0.0 & 0.0 & 0.0 & 0.0 & 0.0 & 0.0 \\
\hline Amortization due & -1.7 & -2.1 & -1.5 & -1.3 & -1.3 & -1.3 & -1.3 & -41.1 & -2.5 & -0.1 & -0.1 & -0.7 & -0.7 & -0.6 \\
\hline Exceptional financing & 0.0 & 0.0 & 0.4 & 1.9 & 1.9 & 2.1 & 2.2 & 2.2 & 2.9 & 0.0 & 0.0 & 0.0 & 0.0 & 0.0 \\
\hline Paris Club ${ }^{6}$ & 0.0 & 0.0 & 0.2 & 0.1 & 0.1 & 0.1 & 0.1 & 0.1 & 0.1 & 0.0 & 0.0 & 0.0 & 0.0 & 0.0 \\
\hline Other $^{7}$ & 0.0 & 0.0 & 0.2 & 1.8 & 1.8 & 2.0 & 2.0 & 2.0 & 2.8 & 0.0 & 0.0 & 0.0 & 0.0 & 0.0 \\
\hline Domestic, net & 1.4 & 1.2 & 1.3 & 1.2 & 1.5 & 1.1 & -0.3 & -2.1 & 1.3 & 1.5 & 1.5 & 1.6 & 1.3 & 1.0 \\
\hline Banking system & 1.4 & 0.5 & 1.2 & 1.3 & 1.0 & 0.1 & 0.7 & -1.0 & -0.5 & 0.2 & -0.3 & -0.5 & -0.5 & -0.6 \\
\hline Counterpart to IMF resources (BEAC) & -0.4 & 0.3 & 0.3 & 0.8 & 0.6 & 0.5 & 0.4 & -1.4 & -0.1 & 0.2 & 0.0 & 0.0 & 0.0 & -0.1 \\
\hline Central Bank & 1.4 & -0.3 & 0.8 & -0.1 & -0.3 & -0.4 & 1.0 & 1.0 & 0.0 & 0.0 & -0.1 & -0.3 & -0.3 & -0.3 \\
\hline Commercial banks & 0.3 & 0.5 & 0.1 & 0.7 & 0.8 & 0.0 & -0.6 & -0.6 & -0.4 & 0.0 & -0.3 & -0.2 & -0.2 & -0.2 \\
\hline Of which: bonds & & & & 0.0 & 0.0 & 2.2 & 0.0 & 0.0 & -0.4 & 1.4 & -0.3 & -0.2 & -0.2 & -0.2 \\
\hline Nonbank $^{8}$ & 0.0 & 0.6 & 0.1 & -0.1 & 0.5 & 1.0 & -1.1 & -1.1 & 1.8 & 1.3 & 1.8 & 2.1 & 1.8 & 1.7 \\
\hline Errors and omissions & 0.0 & 0.6 & -0.6 & 0.5 & 0.6 & 0.0 & 0.1 & 0.1 & 0.0 & 0.0 & 0.0 & 0.0 & 0.0 & 0.0 \\
\hline Residual financing need ${ }^{9}$ & 0.0 & 0.0 & 0.0 & 0.0 & 0.0 & 0.0 & 1.5 & 1.5 & 0.0 & 0.4 & 0.0 & 0.0 & 0.0 & 0.0 \\
\hline Memorandum items: & & & & & & & & & & & & & & \\
\hline Government domestic debt & 24.4 & 23.9 & 24.5 & 21.3 & 22.6 & 18.8 & 22.6 & 19.7 & 19.4 & 18.4 & 17.3 & 16.3 & 15.1 & 14.0 \\
\hline Of which: domestic arrears & 15.4 & 14.2 & 14.1 & 11.8 & 11.7 & 9.4 & 11.7 & 9.9 & 7.2 & 7.9 & 6.0 & 4.3 & 2.8 & 1.4 \\
\hline Spending for DDR & & & & & & & 1.1 & 1.1 & & & & & & \\
\hline
\end{tabular}

Sources: C.A.R. authorities; and IMF staff estimates and projections.

${ }^{1}$ The new classification starts in 2007. It affects mainly revenues. Some fees originally recorded as taxes are now included as nontax revenue.

${ }^{2}$ Expenditures are on a cash basis for current period expenditures, except for interest, which is recorded on a due-basis.

${ }^{3}$ In 2009, includes outlays for the peace process (DDR), of which 80 percent are allocated to transfers and 20 percent to goods and services.

${ }^{4}$ Excludes grants, interest payments, and externally financed capital expenditure.

${ }^{5}$ Figure for 2006 reflects arrears clearance by the World Bank and the AfDB (CFAF 47.5 billion) and the increase in arrears to bilateral and a few multilateral creditors (CFAF 6.9 billion).

${ }^{6}$ Reflects Paris Club rescheduling and moratorium agreement in April 2007.

${ }^{7}$ Includes HIPC debt relief from multilateral and other bilateral creditors. For 2008-09, also includes debt service to non-Paris Club and commercial creditors

For 2010 onward, reflects full delivery of HIPC and MDRI relief on a flow basis.

${ }^{8}$ Includes loan covenants signed with commercial banks domiciliated in CEMAC countries, debt with oil suppliers, and expected future bond issues.

${ }^{9}$ The gaps in 2009 and 2010 projections are equivalent to the proposed augmentation of PRGF access. 
Table 4. Central African Republic: Balance of Payments, 2005-14 ${ }^{1}$

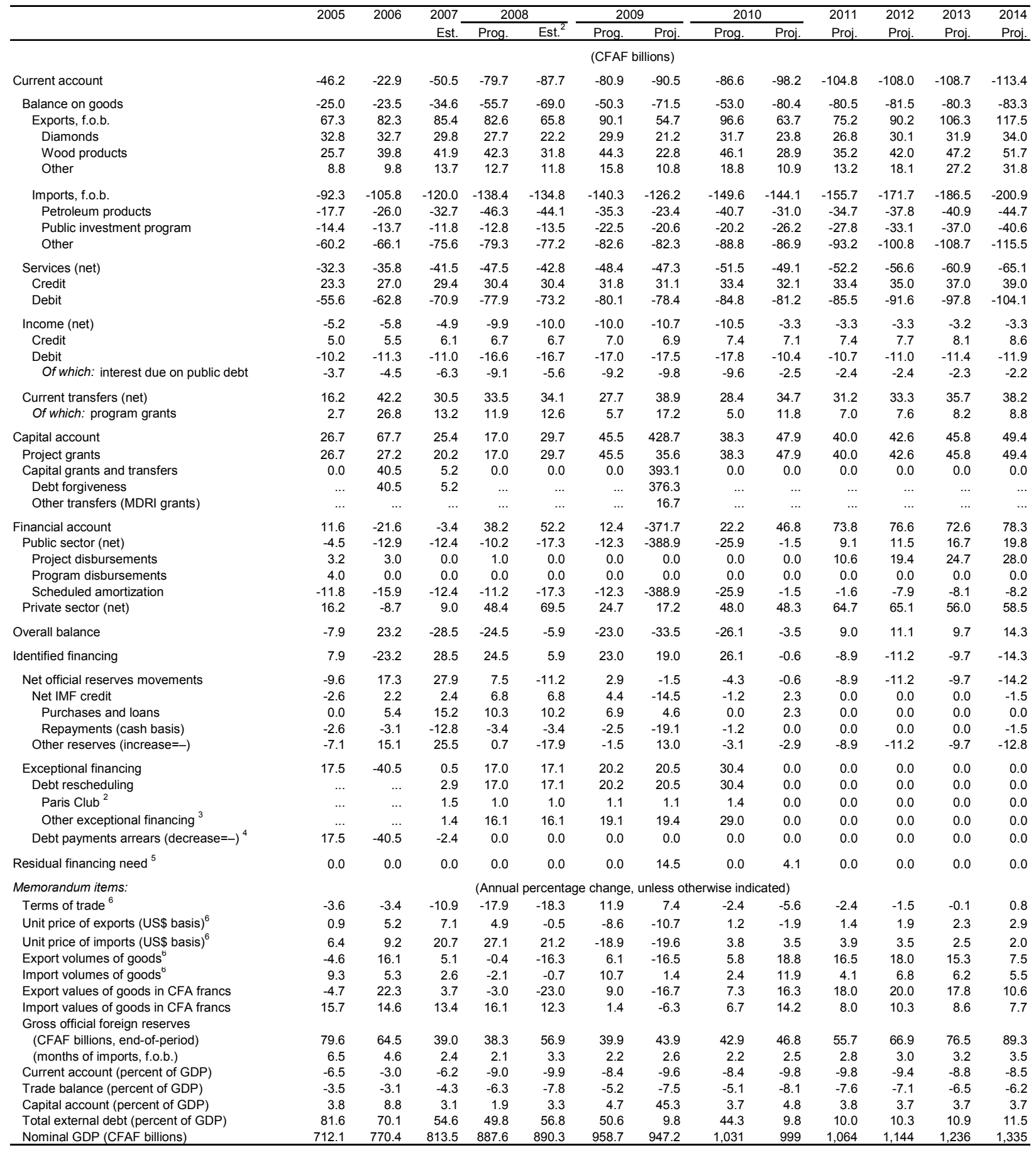

Sources: C.A.R. authorities; and IMF staff estimates and projections.

${ }^{1}$ The macroeconomic framework assumes that the C.A.R. reaches the HIPC completion point in 2009; the balance of payments projections

incorporate debt relief expected to be delivered at the completion point.

${ }^{2}$ Reflects Paris Club rescheduling and moratorium agreement in April 2007.

${ }^{3}$ Includes interim HIPC debt relief from multilateral creditors. For 2008-09, includes debt service to non-Paris Club and commercial creditors.

${ }^{4}$ Figure for 2006 reflects arrears clearance by the World Bank and the AfDB (CFAF 47.5 billion) and the increase in arrears to bilateral and a few

multilateral creditors (CFAF 6.9 billion).

${ }^{5}$ The gaps in 2009 and 2010 projections are equivalent to the proposed augmentation of PRGF access.

${ }^{6}$ Historical price and volume data were recalculated using a new methodology. For comparability purposes, the program numbers for 2008-10 were also recalculated. 
Table 5. Central African Republic: Monetary Survey, 2005-09

\begin{tabular}{|c|c|c|c|c|c|c|c|}
\hline & \multirow[t]{2}{*}{2005} & \multirow[t]{2}{*}{2006} & \multirow[t]{2}{*}{2007} & \multicolumn{2}{|c|}{2008} & \multicolumn{2}{|c|}{2009} \\
\hline & & & & Prog. & Est. & Prog. & Proj. \\
\hline & \multicolumn{7}{|c|}{ (CFAF billions, end of period) } \\
\hline Net foreign assets & 56.2 & 43.0 & 31.6 & 22.5 & 31.2 & 22.4 & 17.5 \\
\hline Bank of Central African States (BEAC) & 59.7 & 43.6 & 17.0 & 7.9 & 27.2 & 7.7 & 13.5 \\
\hline Operations account & 77.0 & 61.6 & 35.8 & 26.5 & 51.5 & 28.1 & 38.4 \\
\hline Use of IMF credit & -20.0 & -21.0 & -22.0 & -30.4 & -29.7 & -32.1 & -30.4 \\
\hline Other & 2.6 & 2.9 & 3.2 & 11.8 & 5.5 & 11.8 & 5.5 \\
\hline Commercial banks & -3.5 & -0.6 & 14.6 & 14.6 & 3.9 & 14.6 & 3.9 \\
\hline Net domestic assets & 72.2 & 80.0 & 86.9 & 105.6 & 106.9 & 116.0 & 110.8 \\
\hline Domestic credit & 126.1 & 135.7 & 143.9 & 161.7 & 159.8 & 166.6 & 168.1 \\
\hline Credit to the public sector & 72.0 & 79.3 & 84.9 & 97.5 & 95.7 & 95.3 & 99.3 \\
\hline Credit to central government (net) & 74.2 & 80.9 & 89.6 & 102.5 & 101.1 & 100.3 & 104.8 \\
\hline BEAC & 67.7 & 70.1 & 77.8 & 84.9 & 82.4 & 82.3 & 92.1 \\
\hline Current account & 32.1 & 36.2 & 16.2 & 14.7 & 17.6 & 10.4 & 20.6 \\
\hline Consolidated loans & 17.2 & 18.4 & 41.1 & 41.1 & 42.0 & 41.1 & 42.0 \\
\hline IMF (net) & 20.0 & 21.0 & 22.0 & 30.4 & 29.7 & 32.1 & 30.4 \\
\hline Deposits & -1.6 & -5.4 & -1.5 & -1.3 & -6.8 & -1.3 & -0.8 \\
\hline Commercial banks & 6.6 & 10.8 & 11.8 & 17.6 & 18.7 & 18.0 & 12.7 \\
\hline Credit to other public agencies (net) & -2.2 & -1.6 & -4.7 & -5.0 & -5.5 & -5.0 & -5.5 \\
\hline Credit to the economy & 54.1 & 56.4 & 59.1 & 64.2 & 64.2 & 71.4 & 68.7 \\
\hline Public enterprises & 5.6 & 5.2 & 4.2 & 4.2 & 2.1 & 4.2 & 2.1 \\
\hline Private sector & 48.5 & 51.3 & 54.9 & 60.0 & 62.0 & 67.2 & 66.6 \\
\hline Other items (net) & -53.9 & -55.7 & -57.1 & -56.1 & -52.9 & -50.7 & -57.3 \\
\hline Money and quasi-money & 128.4 & 123.0 & 118.5 & 128.1 & 138.1 & 138.3 & 128.2 \\
\hline Currency & 89.9 & 80.9 & 59.0 & 60.6 & 72.9 & 62.1 & 61.5 \\
\hline Deposits & 38.6 & 42.0 & 59.5 & 67.5 & 65.2 & 76.2 & 66.7 \\
\hline Demand deposits & 23.8 & 24.5 & 38.3 & 39.4 & 40.8 & 49.0 & 41.8 \\
\hline \multirow[t]{2}{*}{ Term and savings deposits } & 14.7 & 17.5 & 21.2 & 28.1 & 24.3 & 27.2 & 24.9 \\
\hline & \multicolumn{7}{|c|}{ (Annual change, percent of beginning period broad money) } \\
\hline Net foreign assets & 6.1 & -10.3 & -9.3 & -7.7 & -0.4 & -0.1 & -9.9 \\
\hline Net domestic assets & 10.4 & 6.0 & 5.6 & 15.8 & 16.9 & 8.1 & 2.8 \\
\hline Net domestic credit & 9.8 & 7.5 & 6.7 & 15.3 & 13.4 & 3.8 & 6.0 \\
\hline Net credit to central government & 10.3 & 5.2 & 7.0 & 10.9 & 9.7 & -1.7 & 2.7 \\
\hline Credit to the economy & -1.0 & 1.8 & 2.1 & 4.3 & 4.3 & 5.6 & 3.3 \\
\hline \multirow[t]{2}{*}{ Money and quasi-money } & 16.5 & -4.2 & -3.7 & 8.2 & 16.5 & 8.0 & -7.1 \\
\hline & \multicolumn{7}{|c|}{ (Annual percentage change) } \\
\hline Monetary base & 17.4 & -14.8 & -18.4 & -7.2 & 19.8 & 2.5 & -14.0 \\
\hline Credit to the economy & -1.9 & 4.3 & 4.7 & 8.7 & 8.6 & 11.1 & 7.1 \\
\hline Public enterprises & -16.2 & -8.3 & -19.1 & 0.2 & -48.8 & 0.0 & 0.0 \\
\hline Private sector & 0.1 & 5.8 & 7.1 & 9.4 & 13.0 & 11.9 & 7.4 \\
\hline \multicolumn{8}{|l|}{ Memorandum items: } \\
\hline NDA of the central bank (CFAF billions) & 38.6 & 40.1 & 51.3 & 55.4 & 54.6 & 57.2 & 56.9 \\
\hline Monetary base (CFAF billions) & 98.3 & 83.7 & 68.3 & 63.3 & 81.8 & 64.9 & 70.4 \\
\hline Nominal GDP (CFAF billions) & 712.1 & 770.4 & 813.5 & 887.6 & 890.3 & 958.7 & 947.2 \\
\hline \multicolumn{8}{|l|}{ Velocity (GDP/broad money) } \\
\hline End of period & 5.5 & 6.3 & 6.9 & 6.9 & 6.4 & 6.9 & 7.4 \\
\hline
\end{tabular}

Sources: C.A.R. authorities; and IMF staff estimates and projections. 
Table 6. Central African Republic: Access and Phasing Under the Three-Year PRGF Arrangement ${ }^{1}$

\begin{tabular}{|c|c|c|c|c|}
\hline \multirow[t]{2}{*}{ Availability date } & \multicolumn{2}{|c|}{ Disbursements } & \multirow[t]{2}{*}{ Conditions } & \\
\hline & (SDRs) & (Percent of quota) & & \\
\hline December 22, 2006 & $17,600,000$ & 31.6 & Approval of the arrangement & \\
\hline September 27, 2007 & $3,100,000$ & 5.6 & Disbursed upon completion of the first review & \\
\hline June $18,2008^{2}$ & $8,670,000$ & 15.6 & Completion of the second review & \\
\hline November $1,2008^{2}$ & $5,885,000$ & 10.6 & Completion of the third review (end-June 2008 test date) & \\
\hline May 1, 2009 & $14,240,000$ & 25.6 & Completion of the fourth review (end-December 2008 test date) & \\
\hline Of which: augmentation ${ }^{3}$ & $11,140,000$ & 20.0 & & $\sqrt{ }$ \\
\hline October 1, 2009 & $11,455,000$ & 20.6 & Completion of the fifth review (end-June 2009 test date) & \\
\hline Of which : augmentation ${ }^{3}$ & $8,355,000$ & 15.0 & & \\
\hline April 1, 2010 & $8,670,000$ & 15.6 & Completion of the sixth (final) review (end-December 2009 test date) ${ }^{4}$ & \\
\hline Of which: augmentation ${ }^{3}$ & $5,570,000$ & 10.0 & & \\
\hline Total & $69,620,000$ & 125.0 & & \\
\hline
\end{tabular}

Source: IMF staff estimates and projections.

${ }^{1}$ The C.A.R.'s quota is SDR 55.7 million.

${ }^{2}$ Includes augumentation approved at the time of the second review.

${ }^{3}$ Reflects proposed augmentation of 45 percent of quota.

${ }^{4}$ Reflects proposed extension of the PRGF arrangement. 
Table 7. Central African Republic: Indicators of Capacity to Repay the Fund, 2008-18 ${ }^{1}$

\begin{tabular}{|c|c|c|c|c|c|c|c|c|c|c|c|}
\hline & 2008 & 2009 & 2010 & 2011 & 2012 & 2013 & 2014 & 2015 & 2016 & 2017 & 2018 \\
\hline & \multicolumn{11}{|c|}{ Projections } \\
\hline \multicolumn{12}{|l|}{$\begin{array}{l}\text { Fund obligations based on existing credit } \\
\text { (SDR millions) }\end{array}$} \\
\hline Principal & 4.9 & 3.2 & 1.6 & 0.8 & 1.8 & 5.0 & 7.1 & 7.1 & 7.1 & 5.3 & 2.0 \\
\hline Charges and interest & 0.4 & 0.2 & 0.2 & 0.2 & 0.2 & 0.2 & 0.2 & 0.1 & 0.1 & 0.1 & 0.1 \\
\hline \multicolumn{12}{|l|}{$\begin{array}{l}\text { Fund obligations based on existing and prospective credit } \\
\text { (SDR millions) }\end{array}$} \\
\hline Principal & 4.9 & 3.2 & 1.6 & 0.8 & 1.8 & 5.0 & 8.5 & 13.1 & 13.9 & 12.2 & 8.9 \\
\hline Charges and interest & 0.4 & 0.3 & 0.4 & 0.4 & 0.4 & 0.4 & 0.3 & 0.3 & 0.2 & 0.2 & 0.1 \\
\hline \multicolumn{12}{|l|}{ Total obligations based on existing and prospective credit } \\
\hline SDR millions & 5.3 & 3.5 & 2.0 & 1.2 & 2.1 & 5.4 & 8.8 & 13.4 & 14.1 & 12.3 & 9.0 \\
\hline CFAF billions & 3.8 & 2.6 & 1.5 & 0.9 & 1.6 & 4.0 & 6.5 & 9.9 & 10.5 & 9.1 & 6.7 \\
\hline Percent of government revenue & 4.1 & 2.6 & 1.4 & 0.8 & 1.2 & 2.8 & 4.2 & 5.7 & 5.5 & 4.4 & 2.9 \\
\hline Percent of exports of goods and services & 3.9 & 3.1 & 1.5 & 0.8 & 1.3 & 2.8 & 4.2 & 5.8 & 5.6 & 4.5 & 3.1 \\
\hline Percent of debt service $2 /$ & 15.8 & 10.6 & 5.7 & 3.6 & 3.6 & 8.7 & 14.0 & 21.8 & 23.6 & 43.0 & 36.2 \\
\hline Percent of GDP & 0.4 & 0.3 & 0.1 & 0.1 & 0.1 & 0.3 & 0.5 & 0.7 & 0.7 & 0.5 & 0.4 \\
\hline Percent of quota & 9.6 & 6.3 & 3.5 & 2.1 & 3.8 & 9.6 & 15.8 & 24.0 & 25.4 & 22.1 & 16.2 \\
\hline \multicolumn{12}{|l|}{ Outstanding Fund credit $2 /$} \\
\hline SDR millions & 40.9 & 63.4 & 70.4 & 69.6 & 67.9 & 62.9 & 54.4 & 41.3 & 27.4 & 15.2 & 6.3 \\
\hline CFAF billions & 28.8 & 47.1 & 52.0 & 51.3 & 50.0 & 46.3 & 40.2 & 30.5 & 20.3 & 11.3 & 4.7 \\
\hline Percent of government revenue & 31.2 & 47.5 & 49.0 & 44.4 & 38.8 & 33.2 & 25.9 & 17.8 & 10.7 & 5.4 & 2.0 \\
\hline Percent of exports of goods and services & 30.0 & 54.8 & 54.3 & 47.2 & 39.9 & 32.3 & 25.7 & 17.9 & 10.9 & 5.6 & 2.1 \\
\hline Percent of debt service $2 /$ & 121.2 & 190.3 & 203.2 & 208.6 & 113.0 & 101.3 & 86.4 & 67.4 & 45.7 & 53.2 & 25.4 \\
\hline Percent of GDP & 3.2 & 5.0 & 5.2 & 4.8 & 4.4 & 3.7 & 3.0 & 2.1 & 1.3 & 0.7 & 0.3 \\
\hline Percent of quota & 73.4 & 113.7 & 126.4 & 125.0 & 121.8 & 112.8 & 97.6 & 74.2 & 49.2 & 27.3 & 11.3 \\
\hline Net use of Fund credit (SDR millions) & 9.7 & 22.5 & 7.1 & -0.8 & -1.8 & -5.0 & -8.5 & -13.1 & -13.9 & -12.2 & -8.9 \\
\hline Disbursements & 14.6 & 25.7 & 8.7 & 0.0 & 0.0 & 0.0 & 0.0 & 0.0 & 0.0 & 0.0 & 0.0 \\
\hline Repayments and Repurchases & 4.9 & 3.2 & 1.6 & 0.8 & 1.8 & 5.0 & 8.5 & 13.1 & 13.9 & 12.2 & 8.9 \\
\hline \multicolumn{12}{|l|}{ Memorandum items: } \\
\hline Nominal GDP (in billions of CFA francs) & 890 & 947 & 999 & 1,064 & 1,144 & 1,236 & 1,335 & 1,442 & 1,550 & 1,664 & 1,784 \\
\hline Exports of goods and services (in billions of CFA francs) & 96 & 86 & 96 & 109 & 125 & 143 & 157 & 171 & 185 & 201 & 218 \\
\hline Government revenue (in billions of CFA francs) & 92 & 99 & 106 & 116 & 129 & 139 & 155 & 172 & 188 & 208 & 228 \\
\hline Debt service (in billions of CFA francs) ${ }^{2}$ & 24 & 25 & 26 & 25 & 44 & 46 & 47 & 45 & 44 & 21 & 18 \\
\hline
\end{tabular}

Sources: IMF staff estimates and projections.

${ }^{1}$ Assumes a PRGF augmentation of 45 percent of quota (SDR 25.065 million), of which 20 percent of quota (SDR 11.14 million), 15 percent of quota (SDR 8.355 million), and 10 percent of quota (SDR 5.57 million) to be disbursed upon completion of the fourth, fifth, and sixth PRGF reviews, respectively.

${ }^{2}$ Total debt service includes IMF repurchases and repayments. 


\title{
APPENDIX I \\ TRANSLATED FROM FRENCH \\ Central African Republic LETTER OF INTENT
}

Bangui, June 5, 2009

\author{
Mr. Dominique Strauss-Kahn \\ Managing Director \\ International Monetary Fund \\ $70019^{\text {th }}$ Street, NW \\ Washington, DC, 20431 \\ USA
}

Mr. Strauss-Kahn:

1. The government of the Central African Republic has successfully implemented the measures contained in the economic and financial program with the support of the International Monetary Fund through its Poverty Reduction and Growth Facility (PRGF).

2. The attached memorandum of economic and financial policies (MEFP) supplements previous memoranda attached to the letters dated November 30, 2006, September 7, 2007 , June 3, 2008, and December 4, 2008. The last sets out quantitative and structural performance criteria for end-December 2008 for completion of the fourth review (fifth disbursement) of the PRGF arrangement.

3. All quantitative performance criteria for completion of the fourth review under the PRGF arrangement were observed except for the ceiling on commercial bank borrowing. For the ceiling on commercial bank borrowing we request a waiver because the deviation was minor. On the basis of our overall performance and on the strength of the policies set forth in the attached memorandum, we request completion of the fourth PRGF review. We are requesting an augmentation of access under the PRGF arrangement by 45 percent of quota in view of unexpected external shocks stemming from the global slowdown and the time needed to adjust our policies. We request disbursement of the fifth loan in the amount of SDR 14.24 million, including SDR 11.14 million (20 percent of quota) from the augmentation. We also request extension of the program until June 30, 2010, to allow the last reviews of the program to take place on a biannual basis.

4. The government believes that the policies set forth in the attached MEFP will enable it to meet its program objectives but is ready to take any other measures that might be necessary. The Central African Republic will, in accordance with Fund policy, consult with the Fund on the adoption of any measures that may be appropriate and before revising the policies set out in the attached MEFP. The fifth review (sixth disbursement) of the PRGF 
arrangement is expected to be completed no later than the end of December 2009, and the sixth review (seventh disbursement) no later than the end of June 2010.

5. The government intends to make the contents of this letter, the attached MEFP, the Technical Memorandum of Understanding (TMU), and the related staff report available to the public. Therefore, it authorizes the IMF to post these documents on its web site once the Executive Board has concluded the review.

Sincerely yours, $/ \mathrm{S} /$

Prof. Faustin Archange Touadéra

Prime Minister

Attachments: - Memorandum of Economic and Financial Policies

- Technical Memorandum of Understanding 


\section{APPENDIX I \\ ATtaChment I \\ TRANSLATED FROM FRENCH \\ Central African Republic Memorandum of ECONOMiC ANd Financial Policies, 2009-10}

Bangui, June 5, 2009

1. Economic conditions have improved noticeably since the government of the Central African Republic (C.A.R.) began implementing its medium-term macroeconomic and financial program in late 2006 with Fund support. Political and social stability has been strengthened as a result of the Inclusive Political Dialogue (IPD) held in December 2008. The recommendations of the IPD also entail new expenditures, notably those related to the Demobilization, Disarmament and Reintegration (DDR) program, and the organization of the 2010 elections. In recent months and with support of donors, we have taken steps to solve the crisis in the energy sector that caused power outages and disruptions in economic activity in 2008.

2. We are also in the process of restoring debt sustainability. We reached the decision point for the enhanced Heavily Indebted Poor Countries (HIPC) Initiative in September 2007 and are working steadfastly to reach the completion point soon. The total debt relief under the HIPC Initiative and the Multilateral Debt Relief Initiative (MDRI) amounts to CFAF 557 billion (59 percent of GDP), a large part of which will be provided upon reaching the completion point, allowing a reduction of our external debt to CFAF 93 billion by the end of 2009. We are very grateful to the international community, including the IMF, for granting this debt relief and the interim assistance that is being provided until C.A.R. reaches the completion point. Debt relief will allow us to spend more on poverty-reducing projects than would have been possible otherwise.

3. More recently, however, our economy has been severely affected by the global slowdown, which has had a serious impact on our major exports, economic growth, and government revenues since October 2008. We are therefore confronted with additional challenges, but we are convinced that strong policies and program implementation with support from the international community will help us maintain economic stability and create the basis for sustainable economic growth. Nonetheless, given the severity of the crisis and in view of the time needed to adjust our policies to these external shocks, we request an augmentation of access under the current PRGF arrangement by 45 percent of quota, and we are redoubling our efforts to seek additional support from other donors. The increase in access would bring total access to 125 percent of quota, which is consistent with the new access norm for second-time users of the PRGF.

4. This memorandum reviews the medium-term macroeconomic framework and presents the economic and financial policies that will be conducted in the context of the government's program until June 30,2010. The measures and objectives of the program are 
consistent with the Poverty Reduction and Strategy Paper (PRSP) adopted on June 30, 2007, and the first annual report of the implementation of the PRSP adopted in early 2009, both after extensive consultations with major stakeholders. The main conclusions from implementation of the PRSP process are the following: (i) the resources mobilized so far are insufficient to satisfy the financing needs that were identified in the PRSP, and they are concentrated in the area of humanitarian assistance; (ii) resources need to continue to be mobilized and aligned with national priorities; (iii) the effects of the international economic crisis on the C.A.R. economy are strong and require an urgent response to maintain the growth and reform momentum started in 2006; and (iv) the strengthening of human, institutional and technical capacities, and the collaboration with foreign development partners are essential for effective implementation of the PRSP.

\section{Recent Economic Performance and Policies}

\section{A. Macroeconomic Performance and Program Implementation}

5. As a result of a lack of regular electricity supply over several months and a slowdown in our main exports, GDP growth slowed to 2.2 percent in 2008 compared to 3.5 percent expected previously. The most important contribution toward economic growth came from agriculture, whereas forestry was the sector with the most negative contribution. Agriculture, which accounts for 29 percent of GDP, grew by 3.2 percent. Mostly because of food price developments, average inflation reached 9.3 percent in 2008 , compared with a projected 8.6 percent.

6. The global slowdown severely affected the exports of our two main commodities, timber and diamonds, and there is little sign of recovery yet. In the period from November 2008 to February 2009, exports of wood and diamonds dropped by 44 percent in volume terms relative to the same period a year before. Fortunately, a continuing expansion of activity in construction and parts of the services sector-including transportation and telecommunications - compensated for some of the negative external shocks. This is reflected in a solid growth (13 percent in 2008) in credit to the private sector. The banking system has so far been insulated from the global financial crises, and the liquidity position of commercial banks remains strong. In this connection, the entry of a new bank into the C.A.R. market in October 2008 was a very welcome development.

7. Fiscal performance in 2008 was encouraging considering the difficult economic conditions and the electricity crisis. Total domestic revenue was in line with expectations (the related quantitative PC was met). Profits and property taxes were slightly lower than expected, already reflecting the first effects of the economic crisis. Nonetheless, we were able to increase the domestic revenue-to-GDP ratio to 10.4 percent, compared to 8.2 percent in 2005. We missed our target for the floor on accumulation of tax arrears by CFAF 0.7 billion, in part because of poor financial performance of public enterprises, but we were able to reduce substantially the amount of contested tax liabilities.

8. We maintained tight control on cash expenditures, which allowed us to meet the performance criterion (PC) on the domestic primary balance (quantitative PC). Spending in priority areas, notably health and education, reached the related quantitative benchmark, and 
we were able to meet the quantitative indicative targets on domestic arrears repayments. Cash spending on transfers and goods and services accelerated toward the end of the year to avoid the accumulation of arrears. Domestically financed capital spending was slowed down to meet the primary surplus target, in light of the fact that grant-financed capital spending was much stronger than expected. The PC on net claims of the commercial banking system on the government was not observed by a small amount (CFAF 0.1 billion), which mostly reflects the fact that we received the disbursement from the third PRGF review only on December 29, 2008, which was too late to reduce our credit with commercial banks. The quantitative benchmark (QB) on the net present value (NPV) of external debt was met.

\section{B. Progress in Structural Reforms}

9. The government has recently implemented a number of important structural reform measures, particularly in the petroleum sector. The automatic quarterly petroleum product pricing formula adopted on June 1, 2008, ensures full pass-through to consumers of all costs, distribution margins, and taxes, including VAT at the regular rate. We adjusted domestic petroleum prices in January 2009 in line with the agreed mechanism; as a result, subsidies on diesel fuel and heavy fuel oil were fully eliminated, and those on kerosene were substantially reduced. Moreover, we applied the mechanism again in April 2009. In light of the substantial decrease in international oil prices, there was no need to increase any domestic fuel prices; however, to offset other revenue losses we decided to leave domestic fuel prices unchanged, thus eliminating subsidies on kerosene transported by river, although not yet for kerosene transported by road, and safeguarding our domestic tax revenues from petroleum products.

10. Progress has been made in revenue administration reform. We have made significant progress with computerizing the large taxpayer office (LTO) and registering new taxpayers identified in a census. We substantially met the structural benchmark related to increasing the number of audits to reach 30 percent of large taxpayers, all stop-filers, and all VAT declarations with a credit balance. For the VAT declarations, we were able to audit 33 out of 47 cases (70 percent) with a two-month delay, but we have conducted issue-oriented audits for the remaining taxpayers as of February 2009. The creation of an audit department in early April 2009 is also expected to strengthen tax administration. In April 2009, we made the necessary changes to use turnover as the sole criterion for taxpayer classification, with a turnover of CFAF 30 million as the minimum threshold for large taxpayers (end-December 2008 structural benchmark). Initially the LTO will cover some 300 taxpayers. However, to fully implement the benchmark we still need to implement some legislative changes to the VAT, which are discussed below and will be introduced as part of the revised 2009 budget law. The delay was due to the need to receive technical assistance to set up the new system.

11. In the area of public financial management, we redoubled our reform efforts to address deficiencies discovered by the Public Expenditure and Financial Accountability (PEFA) assessment. In particular, we created a liquidity committee (Comité de suivi de la liquidité) in late 2008, with its technical secretariat established in early 2009. The committee works to align expenditure commitments with available resources, taking into account projected cash inflows and outflows, and provides technical inputs and recommendations to the treasury committee. In the context of the 2009 budget law, all revenue, expenditure, and financing items of public agencies (notably the petroleum, telecommunications, and 
electricity regulatory agencies) were integrated into the government budget. A new budget classification was introduced for the 2008 budget, and a related chart of accounts was developed and adopted in January 2009. We made important progress in the computerization of the expenditure chain. In addition, we have improved the monthly reconciliation of government accounts between the treasury and the central bank to ensure that data regarding the net treasury position are consistent. In December 2008, we established and published a plan to clear domestic arrears and restore confidence in our fiscal management. The plan includes a summary of all arrears as of end-2007 and a timetable for payments. We intend to eliminate domestic payment arrears over the next decade, and we will accelerate payments should more financing become available. Given the supply constraints in the economy, some priority is given to repaying arrears to suppliers, in particular those related to utilities and petroleum companies. We will not securitize any of our arrears and will pay cash only.

\section{The Program for 2009 And Medium-Term ObJectives}

12. The government plans to address the impact of the global financial crisis by adjusting to the challenging economic outlook while continuing to adhere to its medium-term objectives. We are committed to maintaining a prudent fiscal stance, reducing arrears, continuing the reform of the petroleum sector, and addressing the financial weakness of stateowned enterprises (SOEs). Despite continued growth in agricultural production estimated at about 3.3 percent and continued expansion of the services sector, real GDP growth is expected at $2 \frac{1}{2}$ percent, a small increase over the 2008 result. However, the new projections are significantly lower than the 4.5 percent previously projected under the program, mainly reflecting weak export activities. We consider these growth projections to be conservative given several ongoing investment projects, the peace process, and better prospects for electricity supply. A good harvest, together with stable international commodity prices, is expected to reduce price pressures; we forecast year-on-year inflation of 1.0 percent for December 2009. Because of price increases in late 2008, average inflation in 2009 would be higher at 4.7 percent, but it is expected to comply with the related CEMAC convergence criterion in 2010.

13. The external shocks stemming from the global slowdown affect the economy mainly through the trade sector. Total exports of goods in 2009 are projected to fall further by CFAF 11.1 billion to CFAF 54.7 billion and will be CFAF 35.4 billion lower than programmed. Imports also will be severely compressed and are projected to increase only by 1.4 percent in volume terms. The current account balance is projected to be almost 10 percent of GDP, similar to the 2008 result despite favorable developments in world oil prices. More significantly, private financial inflows including foreign direct investment are likely to drop significantly - reflecting investors' caution in an uncertain global environment - from an unusually high level realized in 2008. These developments would lead to a reduction in official foreign reserves to 2.6 months of import cover in 2009 from 3.3 months in 2008, despite the augmentation of access requested from the IMF. On the monetary side, the drop in net foreign assets would result in a lower level of broad money (by 7 percent) despite a projected solid increase in credit to the economy (by 7 percent).

14. Our priorities for 2009 are to address the impact of the global crisis on our export sectors while preserving a prudent fiscal stance. Specifically, we will (i) continue improving 
our domestic revenue-raising capacity; (ii) stabilize domestic demand by maintaining budgeted expenditures and integrating expenditures related to the DDR process into a revised budget; (iii) pay all current government obligations and reduce domestic arrears as per the strategy adopted in December 2008; and (iv) maintain the momentum in fiscal structural reforms.

\section{A. Fiscal Policy for 2009}

15. Despite the ongoing economic crisis domestic revenues should rise by 0.1 percentage points to 10.5 percent of GDP. This improvement is the result of the positive impact of fuel taxes, VAT law changes, and more effective revenue administration, which will more than compensate for lower tax receipts from C.A.R.'s main export products and indirect taxes on consumption. Net petroleum revenues should increase by CFAF 6 billion ( 0.6 percent of GDP) relative to 2008, while export tax receipts could fall by CFAF 3 billion (0.3 percent of GDP). Nontax revenue will fall by 0.2 percent of GDP because one-time receipts in 2008 related to the sale of telecommunication licenses will not recur in 2009. The new revenue projections imply lower revenues of CFAF 9 billion compared to the program or CFAF 12 billion (1.3 percent of GDP) compared to the budget. These losses are an indication of the severity of the economic crisis. We will work to ensure that taxes are collected effectively and efficiently and there is no new net accumulation of tax arrears (quantitative benchmark).

16. We intend to support domestic demand in the face of the economic crisis and lower projected revenues by maintaining budgeted expenditures and integrating new priority spending programs related to the peace process. Domestic current primary spending will increase to 9.9 percent of GDP from 9.1 percent of GDP in 2008 in part to reflect spending on the DDR and the preparations for the 2010 elections and to fully pay for current government utility consumption. The wage bill is projected to increase by 0.3 percent of GDP to accommodate an expansion in the number of teachers and health personnel and the unfreezing (débloquage) of salaries from the 1986-96 period. Savings in transfers, mainly because of lower subsidies for petroleum products, will allow for higher expenditure on goods and services, including some repairs of the energy facilities, as well as fully providing for government consumption of electricity, water, and telecommunications. We are committed to fully paying all our current utility bills (quantitative benchmark). Domestically financed capital expenditure will increase by 0.8 percentage points of GDP over 2008; it is directed at improvement of infrastructure that was poorly maintained for many years.

17. The additional expenditure needs related to the peace process and the 2010 elections will require the adoption of a revised budget by July 2009. Expenditure projections include CFAF 10 billion (1.1 percent of GDP, mostly recorded in transfers) for the DDR, which is financed by the UN Peace Consolidation Fund ( $\$ 4$ million) and the CEMAC (CFAF 8 billion). The five other countries in the CEMAC region have agreed to provide a grant of CFAF 1 billion each to C.A.R. (two countries have already provided the assistance), and CFAF 3 billion is provided as an exceptional advance from BEAC, for which the agreement was signed in April 2009. The projections also take into account implementation of recommendations from the IPD, including the domestic contribution to preparation for the 2010 elections (which requires some CFAF 1 billion in 2009). 
18. The domestic primary balance declines in response to peace process spending and the economic crisis. The fall in the domestic primary balance compared to program (1.6 percent of GDP) is mainly explained and financed by greater than previously expected donor financing for the peace process and some carry-overs from 2008 (1.2 percent of GDP). The remainder is due to the debt-financed part of the peace process ( 0.3 percent of GDP) and revenue losses related to the crisis, which are financed domestically. The available financing would allow for further repayment of arrears (1.1 percent of GDP) and reduction of the most onerous credits from commercial banks. This fiscal stance will also allow for continuing reduction of public debt, which will decline from 79.4 percent of GDP in 2008 to 29.6 percent of GDP in 2009, mostly related to HIPC completion point debt relief (estimated at 41.5 percent of GDP).

\section{B. Medium-Term Objectives}

19. We are confident that the structural reform measures we are implementing in the context of the PRGF-supported program and the enhanced HIPC initiative will strengthen our growth prospects and our fiscal and balance of payments positions. Growth should recover and accelerate as private and public investment increases and world demand recovers. In this regard, new investments following implementation of the recently adopted forestry and mining codes will be key; already there are some large mining projects in the pipeline that should start production over the next few years. Our balance of payments position should also recover, although more slowly than desirable, as our main export commodities recover and we start diversifying our export base. Our medium-term fiscal anchor is a domestic primary surplus of about 1 percent of GDP, which we intend to achieve by steadily increasing our tax-to-GDP ratio while stabilizing and later increasing domestic priority expenditures. This fiscal anchor should help us decrease our debt-to-GDP ratio over time as GDP expands.

\section{Structural Reforms}

20. The government has started to harmonize its structural reform program with the support of the donors operating in C.A.R. with the view of improving the predictability of aid. In addition to the IMF, which provides balance of payments support, the donors participating in this process are the African Development Bank, the European Commission, France, and the World Bank. The goal of the harmonized program is to mutually agree on a reform agenda that would also be supported by technical assistance. We will work with the above donors on a program over the coming months.

\section{Tax policy and revenue administration reforms}

21. We continue to make the tax system work better. In January 2009, we started applying VAT on all petroleum products, increased the minimum excise on gasoline and diesel, and reduced subsidies on kerosene in line with the automatic adjustment mechanism for petroleum products, that was converted into a continuous structural benchmark instead of a structural performance criterion. Excises on kerosene will be increased every quarter by some CFAF 40 per liter to completely eliminate any residual subsidies and to reduce the price differential with diesel, which is a close substitute for and often mixed with kerosene in transportation. Moreover, we will create a difference in the margin for importation of 
petroleum products by river versus by road of CFAF 10 per liter to provide a greater incentive to import by river, which is much less costly for the budget and less environmentally risky. As a result, the gross increase in petroleum-related resources for the government budget in 2009, including VAT, is projected at CFAF 13 billion, and the net revenue increase is CFAF 6 billion after subtracting savings in fuel subsidies and VAT input credits.

22. We eliminated the lower VAT rate on building materials and the 10 percent VAT withholding that were introduced in the 2008 budget law. We also now allow for the deductibility of VAT credits for petroleum products used in the process of production and are working to improve the payment of VAT refund requests (structural benchmark for end2009): for reliable taxpayers, who submit refund requests in line with legislative requirements, we intend to pay 50 percent of the refund request within 30 days and the remainder after 90 days, although the final amount could be reduced as part of the verification of the refund request. In the context of the revised 2009 budget, we will amend Article 247 of the tax code to clarify that turnover is the only criterion for whether taxpayers are subject to the VAT, independent of their legal status (physical or legal person).

23. Taxpayer compliance is a permanent priority. In 2009 again, we will audit at least 30 percent of large taxpayers, all stop-filers among large taxpayers, and all VAT declarations with a credit or zero balance. This should allow us to achieve a nonfiler rate of less than 10 percent. To achieve a better targeting of audits we will nominate a director of the audit department and related personnel by end-June 2009 and create an audit plan, which will be reviewed with respect to its effectiveness in 2010. We will increase the resources available for the tax and customs administrations to ensure that they are in line with the increased demands and expectations that are placed on them, including by providing adequate office space to the large taxpayer office. The tax and customs administrations' information systems (SYSTEMIF and ASYCUDA) are now interconnected, but in order to meet the related end-June 2009 structural benchmark, we still have to enhance the system's capability to allow for the automatic exchange of relevant taxpayer-specific information in a user-friendly way.

24. Customs revenue collection will continue to play an important role, and we intend to reinforce our policy and administrative efforts in this area. Making good use of the ASYCUDA system will help improve customs administration, and we intend to expand its use and capabilities forcefully in cooperation with our technical assistance partners. We have already reduced customs exemptions from CFAF 17 billion in 2007 to CFAF 12 billion in 2008. Customs exemptions will be reduced further with a view to eliminating discretionary exemptions altogether and to limiting statutory exemptions only to those with a clear economic rationale: the scope of this rationalization of exemptions will be identified in the context of the fifth review under the PRGF arrangement, and implementation is expected by end-December 2009 (structural benchmark). To this effect, the interministerial committee in charge (CICEFD) will prepare a comprehensive review of discretionary and statutory customs exemptions by end-June 2009. In addition, we will further increase the efficiency of customs administration by providing adequate resources and stepping up efforts to train personnel in various priority areas, and we will work toward facilitating transit procedures between the Douala port and the final destination. 
25. We will also strengthen border control, particularly with respect to petroleum products, given incentives for smuggling stemming from differences in petroleum product prices compared to those in neighboring countries. We have recently decided to limit the activities of the private company SODIF and the state agency CEMIFI to ex post controls in order to strengthen the capacity of the tax and customs administrations in revenue collection. This will also avoid the duplication of collection and enforcement work, which is sometimes perceived as an unnecessary burden on taxpayers. Thus, SODIF and CEMIFI will coordinate their ex post verification plan with the customs and tax departments, to whom they will supply any relevant enforcement information resulting from their activities. We will continue to assess the performance of SODIF and CEMIFI on a quarterly basis.

26. The government is committed to improving data availability for the petroleum sector and eliminate progressively any related fraud. With the help of the World Bank, we have arranged for technical assistance for the control of the quality and volumes of imported petroleum products at the place of origin before transit and at the point of unloading in C.A.R. Also, we will carefully monitor the implementation of differentiated kerosene prices for small and other consumers - introduced in February 2009-with the view of limiting fraudulent use of kerosene. The government has also contracted technical assistance supported by the World Bank to help revise the existing legislation and regulation of the petroleum sector with a view to harmonizing the legal text and clarifying the roles of the respective operators.

27. In preparation for comprehensive tax reform, we unified all tax-related legislation into a single tax code and published it on the Internet, and we will keep this information base updated. In addition, we intend to request technical assistance from the IMF for the second half of 2009 for a comprehensive revision of the tax code with a view to making it simpler, more efficient, and revenue-enhancing. Already we have started to prepare for the reform by requesting technical assistance from the European Union in preparation for this reform. This would allow us to make important progress with tax policy reforms during 2010 and put in place a new tax code with the 2011 budget.

\section{Public financial and debt management reforms}

28. Government's priorities for public financial management reforms are to (i) strengthen liquidity management; (ii) improve expenditure tracking; (iii) enhance debt management; and (iv) increase budget transparency. To this end, we intend to take the following steps:

- We will strengthen the work of the liquidity committee. The liquidity committee is an important tool in implementing our fiscal policies and responding to developments in the course of the budget year. The liquidity committee will prepare rolling projections of expenditure commitments, revenues, and debt service requirements for the forthcoming week, month, quarter, and remainder of the year. Based on these constantly updated projections, the liquidity committee will provide written recommendations on adjusting expenditure commitments in line with the forecasts to the treasury committee, which is in charge of strategic policy decisions related to budget implementation. 
- We will establish a treasury single account (TSA). We have made significant progress toward creating a TSA by closing 51 accounts at commercial banks and auditing most accounts between end-June 2008 and end-March 2009. However, more time is needed to properly implement the TSA, which is now expected to be fully operational by end-December 2009 (structural benchmark). The reason for the delay is that more technical work is needed to design the operation of commercial bank accounts on a zero-balance basis. We intend to work closely with FAD/AFRITAC technical assistants to resolve these problems.

- We will ensure that all expenditure commitments are integrated into Gesco and that payment orders are issued as soon as the related service has been delivered. The new expenditure tracking system will also include all expenditures without prior commitment or payment order, as for example those for debt service, salaries, and utility bills or petroleum product consumption. To better monitor our expenditures, we will measure delays in processing expenditure at all stages after commitment by extending the Gesco system to the treasury and ensuring that all spending, including that of line ministries, is reflected in the system (structural benchmark for endDecember 2009). A further extension of Gesco, which will include the recording of transactions by the revenue agencies, is planned for the first half of 2010.

- We will ensure that the stock of arrears declines on a net basis during 2009 (quantitative benchmark). For program purposes, expenditure arrears are defined as payment orders issued (ordonnancement) and not paid after 60 days. Moreover, we will record all domestic arrears from previous years in the computerized debt database of the debt department on an arrear by arrear basis (structural benchmark for end-December 2009). This will help implement the arrears repayment strategy by integrating the repayment plan for arrears in the debt service forecasts of the debt department.

- We will revise the conventions between the government and domestic commercial banks to ensure that commercial banks no longer have control over government resources and will consolidate past loans into one new loan with lower interest rates, a grace period, and a 3-year maturity. All conventions signed between the government and domestic commercial banks were audited as a first step toward consolidation and refinancing of our debt with them. All government receipts are deposited in the main treasury account at the central bank (BEAC) (end-June 2009 structural benchmark).

- We will revise the 1988 law and decree on government guarantees and require that the recipient pay a fee for any such guarantee to strengthen our legal framework for issuing government guarantees. In this context, we have made it clear that all domestic and external guarantees need to be prepared by the debt department (the lead government agency with respect to guarantees), signed by the Minister of Finance, and recorded in the debt statistics. Moreover, these guarantees also need to 
be included ex post in the annual budget law. The legal amendments will be included in the revised 2009 budget law and therefore the timing of this structural benchmark will be changed from end-June to end-September 2009.

- We will continue to improve debt management to reduce our financing costs. Effective implementation of our financial strategy would require issuance of government securities in the regional market; we expect this to take place only in 2010 because of the preparations still needed at the regional and national levels. We have asked the Fund to assist us in this process with technical assistance, which we expect to receive by mid-year.

- We will publish quarterly budget execution reports to increase transparency and better communicate government fiscal policies. In 2008, we started preparing quarterly budget execution reports, which we shared with donors. We believe that these reports are an important tool for informing the public about recent fiscal developments, including difficulties in implementing policies.

\section{Public utilities and municipalities}

29. We are determined to work to improve the financial performance of the public utility companies. We will keep up the monitoring of the combined collection ratio (cash collections divided by amount billed) for the three major utility companies (electricity, water, and telecommunications). The collection ratio was 67 percent at end-2008, and we are targeting a gradual increase of 15 percentage points during 2009 (quantitative benchmark); full payment of current utility bills by the government will help achieve this improvement (quantitative benchmark). The arrears repayment plan adopted in December 2008 allows for the gradual reduction of utility payment arrears of the government. This will contribute to improving the financial situation of the public utility companies and will make it possible for them, in turn, to repay their tax arrears, which are as follows: ENERCA (CFAF 1 1 $\frac{1}{2}$ billion), SOCATEL (CFAF 3 $1 \frac{1}{2}$ billion), and SODECA (almost CFAF 1 billion). For ENERCA, we are benefiting from technical and financial support from the World Bank ( $\$ 8$ million) and the French Development Agency (€4.2 million) for rehabilitation of the system and maintenance of the currently installed capacity of 18 megawatts of electricity. We intend to work closely with donors to identify financing for the installation of turbines in Boali, our main hydrogeneration facility, to increase electricity production to 28 megawatts, which would be a great step forward in ensuring stable energy supplies to consumers and facilitating economic growth. We will also accelerate our work with donors to stabilize and secure the existing electricity supply.

30. We also envisage repaying part of the government's arrears to the municipality of Bangui. Since the municipality has accumulated arrears with the electricity company ENERCA, the central government will pay part of its debt to the municipality directly to ENERCA to enable the company to acquire additional meters and improve tariff collection. We will continue to fully transfer any shared revenues and disburse the regular transfers to the municipality of Bangui (about CFAF 350 million) to help the municipality become 
current on its payments. We will also analyze the appropriate way to address payment for public lighting in Bangui.

\section{Program Monitoring}

31. The program will be monitored through biannual reviews of quantitative performance criteria (PCs) for end-June and end-December 2009 (Table 1), and benchmarks for 2009/10 (Table 2). Detailed definitions and reporting requirements for all quantitative PCs and structural conditions are contained in the accompanying Technical Memorandum of Understanding (TMU, Attachment II). The government will make available to Fund staff all core data, appropriately reconciled, on a regular and timely basis, as specified in the TMU. 
Table I.1. Central African Republic: Quantitative Performance Criteria and Benchmarks under the PRGF Arrangement, December 2008-December 2009

(billions of CFA francs; cumulative from December 31, 2007 for 2008 and from December 31, 2008 for 2009; ceilings, unless otherwise indicated)

\begin{tabular}{|c|c|c|c|c|c|c|c|}
\hline & \multirow[t]{2}{*}{$\begin{array}{c}\text { End-Dec. } 2008 \\
\text { Outcome } \\
\end{array}$} & \multirow{2}{*}{$\begin{array}{c}\text { End-Mar. } 2009 \\
\text { Benchmark } \\
\text { Program }\end{array}$} & \multicolumn{2}{|c|}{$\begin{array}{c}\text { End-Jun. } 2009 \\
\text { Performance Criteria } \\
\end{array}$} & \multicolumn{2}{|c|}{$\begin{array}{c}\text { End-Sep. } 2009 \\
\text { Benchmark }\end{array}$} & \multirow{2}{*}{$\frac{\text { End-Dec. } 2009}{\text { Performance Criteria }}$} \\
\hline & & & Program & $\begin{array}{l}\text { Revised } \\
\text { program }\end{array}$ & Program & $\begin{array}{l}\text { Revised } \\
\text { program }\end{array}$ & \\
\hline \multicolumn{8}{|l|}{ Performance criteria } \\
\hline Floor on total government revenue ${ }^{1}$ & 92.5 & 26.0 & 51.4 & 47.6 & 78.4 & 73.5 & 98.1 \\
\hline Floor on domestic primary balance ${ }^{2}$ & 0.7 & 2.9 & 4.3 & 1.5 & 4.1 & -1.6 & -9.7 \\
\hline $\begin{array}{l}\text { Change in net claims of the commercial banking system on the } \\
\text { government excluding bonds issued on the regional market }\end{array}$ & 6.9 & 0.6 & & -26 & 0.0 & & -50 \\
\hline New nonconcessional external debt ${ }^{34}$ & $\begin{array}{l}6.9 \\
0.0\end{array}$ & 0.0 & $\begin{array}{r}-3.8 \\
0.0\end{array}$ & $\begin{array}{r}-2.6 \\
0.0\end{array}$ & 0.0 & $\begin{array}{r}-7.9 \\
0.0\end{array}$ & $\begin{array}{r}-5.0 \\
0.0\end{array}$ \\
\hline Accumulation of government external payments arrears ${ }^{4}$ & 0.0 & 0.0 & 0.0 & 0.0 & 0.0 & 0.0 & 0.0 \\
\hline \multicolumn{8}{|l|}{ Indicative targets } \\
\hline NPV of external debt & 336 & $\ldots$ & $\ldots$ & $\ldots$ & $\ldots$ & $\ldots$ & 114 \\
\hline Floor on poverty-related spending ${ }^{5}$ & 19.7 & 5.0 & 10.0 & 10.0 & 15.0 & 15.0 & 21.0 \\
\hline Floor on reduction in domestic payments arrears & 10.5 & 2.0 & 1.0 & 1.0 & 7.5 & 6.0 & 9.0 \\
\hline Net accumulation of tax arrears & 2.1 & 0.0 & 0.0 & 0.0 & 0.0 & 0.0 & 0.0 \\
\hline Floor on cash collections of utility companies (in percent) & 67.4 & 69.4 & 73.4 & 73.4 & 77.4 & 77.4 & 82.4 \\
\hline Floor on government payment of utility bills (in percent) & $\ldots$ & 98.0 & 98.0 & 98.0 & 98.0 & 98.0 & 98.0 \\
\hline \multicolumn{8}{|l|}{ Memorandum items: } \\
\hline Projected grants for budget support & 12.6 & 2.4 & 5.7 & 6.8 & 5.7 & 14.2 & 17.2 \\
\hline Projected bonds issued in the regional market & 0.0 & 0.0 & 0.0 & 0.0 & 15.5 & 0.0 & 0.0 \\
\hline Of which: held by domestic commercial banks & 0.0 & 0.0 & 0.0 & 0.0 & 10.5 & 0.0 & 0.0 \\
\hline \multicolumn{8}{|l|}{ Maximum adjustor for government net claims on } \\
\hline commercial banks in case of grants shortfalls & & 2.4 & 5.0 & 5.0 & 5.0 & 6.0 & 6.0 \\
\hline External financing without project loan disbursement & 5.8 & 2.0 & 3.1 & 3.9 & 5.1 & 6.3 & 7.9 \\
\hline Repayments to oil companies and on commercial loans ${ }^{6}$ & $\ldots$ & $\ldots$ & $\ldots$ & 6.1 & $\ldots$ & 8.1 & 10.1 \\
\hline
\end{tabular}

Sources: C.A.R. authorities; and IMF staff estimates.

${ }^{1}$ Domestic revenue, which excludes foreign grants and divestiture receipts (see the Technical Memorandum of Understanding for more details).

${ }^{2}$ The domestic primary balance (cash basis) is defined as the difference between government domestic revenue and government total expenditure,

less all interest payments and externally-financed capital expenditures.

${ }^{3}$ Contracted or guaranteed by the government (see the TMU).

${ }^{4}$ These performance criteria will be monitored continuously.

${ }^{5}$ Total spending on health and education including wages and salaries and goods and services.

${ }^{6}$ Debt owed to oil companies and loan covenants with financial groups domiciliated in the CEMAC, classified as nonbanks. 
Table I.2. Central African Republic: Structural Benchmarks, 2009-10

\begin{tabular}{|c|}
\hline Measure \\
\hline REVENUE ADMINISTRATION AND TAX POLICY \\
\hline 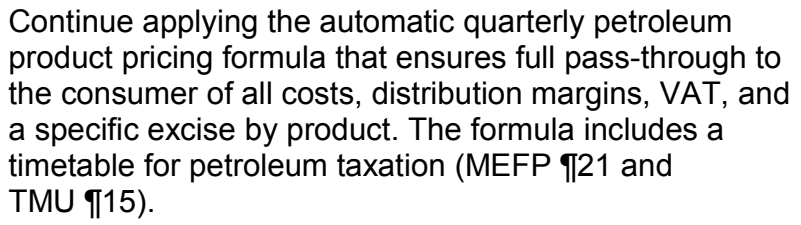 \\
\hline $\begin{array}{l}\text { For reputable taxpayers that demand VAT refund } \\
\text { requests, pay } 50 \text { percent of refund request within } \\
30 \text { days, and the remainder after } 90 \text { days unless } \\
\text { verification shows lower payment is warranted } \\
\text { (MEFP } \$ 22 \text { ). }\end{array}$ \\
\hline $\begin{array}{l}\text { Interconnect the tax administration's SYSTEMIF and } \\
\text { customs administration's ASYCUDA++ computer } \\
\text { systems to share relevant taxpayer information } \\
\text { (MEFP श23). }\end{array}$ \\
\hline $\begin{array}{l}\text { Reduce customs exemptions with the aim of eliminating } \\
\text { discretionary exemptions and statutory exemptions with } \\
\text { limited economic rationale (MEFP } \mathbb{\| 2 4} \text { ). }\end{array}$ \\
\hline
\end{tabular}

\section{PUBLIC FINANCIAL AND DEBT MANAGEMENT}

Implement a treasury single account (TSA) (MEFP \28).

Revise the 1988 law and decree on government guarantees to strengthen our legal framework for issuing government guarantees by requiring that the recipient pay a fee for any guarantee. Clarify that all domestic and external guarantees need to be signed by the Minister of Finance after consultation with the debt department, and recorded in the debt statistics (MEFP $\mathbb{2} 28$ ).

Revise conventions with commercial banks to ensure that they no longer have control over government money. Thus, all government receipts will be deposited in the main treasury account at the central bank (BEAC) (MEFP П28).

Finalize the implementation of the government financial management system by fully applying Gesco to all stages of the expenditure process from commitment to payment (MEFP $\llbracket 28)$.

Integrate all domestic arrears from previous years in the computerized debt database of the debt department (MEFP П28).
Timeline Macroeconomic Rationale

\begin{tabular}{|c|c|}
\hline $\begin{array}{l}\text { Continuous } \\
\text { (used to be a } \\
\text { structural } \\
\text { performance } \\
\text { criterion) }\end{array}$ & $\begin{array}{l}\text { Protect the budget from risks of } \\
\text { fluctuating petroleum prices; } \\
\text { create room for well-targeted } \\
\text { measures to mitigate the social } \\
\text { impact of petroleum price } \\
\text { changes. }\end{array}$ \\
\hline
\end{tabular}

End-December Make exports more competitive by 2009 allowing zero rating of VAT liabilities in line with international best practice.

End-June 2009 Enhance revenue-generation potential by reducing the scope for tax evasion.

End-December 2009

Enhance revenue-generation potential.

Delayed from end-June to end-December 2009

Delayed from end-June to end-September 2009

Reduce financing costs for the government and increase transparency of government operations.

Limit contingent liabilities for the budget and provide better incentives for public or private enterprises.

End-June 2009 Reestablish government control over its finances and increase the transparency of government operations.

End-December 2009

Improve fiscal control and avoid arrears.

End-December 2009
Enhance capacity to manage domestic debt.

Source: IMF staff estimates. 


\section{APPENDIX I \\ ATTACHMENT II \\ TRANSLATED FROM FRENCH \\ Central African Republic \\ TECHNICAL MEMORANDUM OF UNDERSTANDING}

1. This Technical Memorandum of Understanding describes the definitions that are intended to clarify the measurement of the quantitative performance criteria and indicators in Table 1 of the Memorandum of Economic and Financial Policies, 2009, attached to the authorities' Letter of Intent. It also specifies the periodicity and deadlines for transmission of data to the staff of the International Monetary Fund (IMF) for program monitoring purposes. Unless otherwise specified, all 2009 quantitative performance criteria and indicative targets will be evaluated in terms of cumulative flows from December 31, 2008.

\section{A. Provision of Data to the Fund}

2. Data with respect to all variables subject to performance criteria and indicative targets will be provided to Fund staff on a regular basis - with the data and timing indicated in Table 1-including any revisions, which will be transmitted in a timely manner. In addition, the authorities will consult with IMF staff on any information and data that become available that are relevant for assessing or monitoring performance against the program's objectives but are not specifically defined in this memorandum.

\section{B. Definitions}

3. Unless otherwise indicated, the government is defined as the central government of the Central African Republic (C.A.R.) and does not include local governments, the central bank, or any public entity with autonomous legal personality (i.e., wholly or partially owned state enterprises) not currently covered by the consolidated government financial operations table (Tableau des opérations financières de l'État-TOFE).

4. Government expenditure on a commitment (engagement) basis (except for interest payments, which are on a due basis) includes all earmarked spending, treasury operations, the domestic counterparts to foreign-financed projects, and offsetting operations. Poverty-related spending on health and education will be reported from the functional classification of government expenditure. Starting in 2009, detailed government expenditure in the TOFE will be reported on a commitment (engagement) basis, and this information would be complemented by the change in the aggregate stock of expenditures committed without payment order (dépenses engagées non-ordonnancées) and the change in the aggregate stock of expenditures with payment orders not paid (dépenses ordonnancées non-payées), which would be divided into those younger than 60 days and those older than 60 days. 
5. For the purposes of this memorandum, the definitions of "debt" and "concessional borrowing" are as follows:

- The term "debt" has the meaning set forth in point No. 9 of the Guidelines on Performance Criteria with Respect to Foreign Debt (Executive Board Decision No. 12274-00/85, August 24, 2000) but also to commitments contracted or guaranteed for which value has not been received. For purposes of these guidelines, the term "debt" is understood to mean a current, that is, not contingent, liability, created under a contractual arrangement through the provision of value in the form of assets (including currency) or services, and which requires the obligor to make one or more payments in the form of assets (including currency) or services, at some future point(s) in time; these payments will discharge the principal and/or interest liabilities incurred under the contract. Debts can take a number of forms, the primary ones being as follows: (i) loans, that is, advances of money to the obligor by the lender made on the basis of an undertaking that the obligor will repay the funds in the future (including deposits, bonds, debentures, commercial loans, and buyers' credits) and temporary exchanges of assets that are equivalent to fully collateralized loans, under which the obligor is required to repay the funds, and usually pay interest, by repurchasing the collateral from the buyer in the future (such as repurchase agreements and official swap arrangements); (ii) suppliers' credits, that is, contracts where the supplier permits the obligor to defer payments until some time after the date on which the goods are delivered or services are provided; and (iii) leases, that is, arrangements under which property is provided that the lessee has the right to use for one or more specified periods of time that are usually shorter than the total expected service life of the property, while the lessor retains the title to the property. For the purpose of the guideline, the debt is the present value (at the inception of the lease) of all lease payments expected to be made during the period of the agreement, excluding those payments that cover the operation, repair, or maintenance of the property. Under the definition of debt set out above, arrears, penalties, and judicially awarded damages arising from the failure to make payment under a contractual obligation that constitutes debt are debt. Failure to make payment on an obligation that is not considered debt under this definition (e.g., payment on delivery) will not give rise to debt.

\section{Quantitative Performance Criteria}

\section{Government domestic revenue (floor)}

6. Government domestic revenue is as reported in the TOFE, and it includes offsetting operations in revenue and current-period expenditure - between the government and all suppliers of goods and services - excluding foreign grants and divestiture receipts. Government revenue includes all tax and nontax revenue, as well as earmarked revenue, checks for project-related customs duties, and withholdings from civil service wages and salaries actually paid. 


\section{Domestic primary fiscal balance (floor)}

7. The domestic primary fiscal balance, on a cash basis, is defined as the difference between government domestic revenue and government expenditure, excluding all interest payments and externally financed capital expenditure. Starting in 2009, the domestic primary balance will be measured on a commitment basis (base engagement). The domestic primary fiscal balance will be calculated from above the line with the data provided in the TOFE.

\section{Adjuster}

8. The floor on the domestic primary fiscal balance will be adjusted downward for any excess in foreign budget support grants relative to program projections.

Change of net claims of the commercial banking system on the government (ceiling)

9. The end-of-period stock of net claims of the commercial banking system on the government (net of purchases of government securities) is defined as the difference between deposits held by the government in commercial banks and outstanding loans and overdrafts as reported in the monetary survey minus commercial bank purchases of government securities.

\section{Adjuster}

10. The ceiling on the change of net claims of the commercial banking system on the government (net of purchases of government securities) will be

i. increased by 100 percent of any cumulative shortfalls in external budget support grants compared to program projections up to the limit specified in Table 1 of the MEFP;

ii. decreased by 57 percent of regional bond issuances;

iii. increased (decreased) by 100 percent of any cumulative excess (shortfall) compared to program projections in external financing (without project loan disbursements); and

iv. decreased (increased) by 100 percent of any cumulative shortfall (excess) repayments of debt to domestic petroleum companies and/or CEMAC-based commercial banks (for borrowing before December 31, 2008).

\section{Nonconcessional external debt or guarantees (ceiling, continuous)}

11. The performance criterion on the contracting of new nonconcessional external debt applies to both short- (original maturity of one year or less) and medium- and long-term (original maturity of more than one year) external debt contracted or guaranteed by the government. Purchases from the IMF are excluded from this limit. 
12. Loan concessionality is assessed on the basis of the commercial interest reference rates (CIRRs) established by the Organization for Economic Cooperation and Development (OECD). A loan is said to be on concessional terms if, on the date the contract is signed, the ratio of the present value of the loan, calculated on the basis of the reference interest rates, to its nominal value is less than 65 percent (that is, a grant element of at least 35 percent, which does not apply to refinancing operations). For debts with a maturity exceeding 15 years, the 10-year CIRR published by the OECD is used to calculate the grant element. For shorter maturities, the 6-month market reference rate is used. To both the 10-year and 6-month averages of the reference rate, the following margins will be added: 0.75 percent for repayment periods of less than 15 years; 1 percent for 15-19 years; 1.15 percent for 20-29 years; and 1.25 percent for 30 years or more.

13. The concept of government for the purpose of the indicator on external debt includes government as defined in paragraph 3 , administrative public institutions, public enterprises authorized to contract, guarantee, or accommodate nonconcessional borrowing, scientific and technical public institutions, professional public institutions, industrial and commercial public institutions, and local governments.

\section{External payment arrears (ceiling, continuous)}

14. External payment arrears are deemed to accrue when undisputed interest or amortization payments of the government are not made within the terms of the contract or in conformity with any future deferral agreed with the Paris Club or other bilateral and commercial creditors.

\section{Structural Benchmarks}

\section{Automatic petroleum product pricing formula (continuous structural benchmark)}

15. The automatic petroleum product pricing formula is designed to ensure full passthrough to the consumer of all costs, distribution margins, a minimum specific excise inclusive of customs duties by product, and VAT at the regular rate.

- $\quad$ The minimum retail price for gasoline (super), kerosene (pétrole lampant), diesel (gasoil), and fuel oil (fuel 1\%) will be calculated by using the price structure of petroleum products transported by river through the Democratic Republic of the Congo by applying the specific excise as shown in Table 2 .

- $\quad$ The formula will be calculated at the end of each quarter, using the average f.o.b. price for the previous 90 days for each product (see Table 2), and this retail price will apply for the 3 months of the next quarter.

- The formula adds all costs, distribution margins, a specific excise by product, and VAT. Thus, the minimum retail price will be the sum of (i) the f.o.b. import price, (ii) all costs and margins, (iii) the minimum specific excise, and (iv) VAT, which is applied at the regular rate to the sum of (i)-(iii).

- The minimum specific excise is defined to include the following items (i) droit de douane; (ii) taxe communautaire d'intégration; (iii) redevance d'usage routier; 
(iv) redevance équipement informatique finances; (v) C.C.I.; (vi) constitution du stock de sécurité; (vii) financement extension capacités de stockage; (viii) péréquation sur le transport; (ix) redevance ASRP; (x) contrôle qualité et quantité des produits, and (xi) soutien ou reversement de l'État, which was previously called negative or positive TUPP, as the residual.

- $\quad$ Should one or more actual fuel excises as defined in the preceding bullet fall below the minimum excise specified in Table 2 but the projected excise revenue for all fuel products for the relevant month exceeds the monthly program target, then for program purposes, the continuous SB on the automatic adjustment would be considered met.

- $\quad$ The same amount of VAT will be charged for petroleum products imported by road via Cameroon or by river via Kinshasa because the retail price is the same; the specific excise will be adjusted to yield the same final price as specified above.

- $\quad$ The retail price for each product would remain fixed for the quarter; however, the price structure would be issued on a monthly basis with the excise adjusting as a function of the changes in other costs. The VAT would remain unchanged.

\section{E. Quantitative Benchmarks}

\section{Net present value of external debt (ceiling)}

16. The NPV of external debt is estimated using the IMF's external debt sustainability analysis template for low-income countries.

\section{Reduction in domestic payments arrears (floor)}

17. The reduction in domestic payment arrears measures the change in the stock of total arrears during the period. Thus, a repayment of existing arrears reduces the stock of arrears whereas the accumulation of new arrears adds to the stock. For purposes of the program new arrears are defined on a payment order basis, i.e., as an expenditure for which a payment order has been issued (dépense ordonnancée), that has not been paid after 60 days.

\section{Adjuster}

18. The floor on the reduction in domestic payments arrears will be increased by 29 percent of the regional bond issuance.

\section{Net accumulation of tax arrears (ceiling)}

19. Net accumulation of tax arrears is defined as the difference in the stock of tax arrears (excluding any amount in litigation) during the period plus any write-offs during that period. 


\section{Poverty-related spending (floor)}

20. Poverty-related spending comprises spending on the following sectors: education, health, rural development, and social affairs, both spending for the current year and arrears repayment related to these sectors.

\section{Government payment of utility bills (floor, cumulative)}

21. The quantitative benchmark applies to utility bills issued by public enterprises Enerca, Socatel, and Sodeca, and is deemed met when at least 98 percent of the combined utility bills issued by these companies are paid within 60 days of the bill issue date. For example, the benchmark for end-March 2009 would measure payments on utility bills from January to March 2009 divided by the utility bills issued November 2008 through January 2009. The benchmark for end-June would measure the payments on utility bills from January to June divided by the utility bills issued November through April.

\section{Collection ratio of utility companies (floor, cumulative)}

22. The target is measured as the cumulative ratio of total period-t cash collections to total bills issued during the period with a two-month lag. The target is defined jointly for ENERCA, SOCATEL, and SODECA. For example, the target for the first quarter would be the sum of cash collections for the three companies for January-March, 2009, divided by the value of bills issued November 2008-January 2009. The benchmark for end-June would measure the sum of cash collections from January to June 2009 divided by the value of bills issued November 2008 through April 2009. 
Table 1. Central African Republic: Data Provision under the PRGF Arrangement

\begin{tabular}{|c|c|}
\hline Data Description & Reporting Lag \\
\hline $\begin{array}{l}\text { Quarterly evaluation report of quantitative and structural } \\
\text { measures (particularly regarding structural conditionality, see } \\
\text { Table } 2 \text { of the MEFP), including supporting documentation. }\end{array}$ & $\begin{array}{l}\text { Four weeks after each quarter's } \\
\text { end. }\end{array}$ \\
\hline $\begin{array}{l}\text { Monthly monetary survey and central bank and commercial } \\
\text { bank accounts. }\end{array}$ & $\begin{array}{l}\text { Four weeks after the end of each } \\
\text { month. }\end{array}$ \\
\hline Table on monthly treasury operations. & $\begin{array}{l}\text { Four weeks after the end of each } \\
\text { quarter. }\end{array}$ \\
\hline Government budget operations (TOFE). & $\begin{array}{l}\text { Four weeks after the end of each } \\
\text { month. }\end{array}$ \\
\hline $\begin{array}{l}\text { End-of-period stock of domestic arrears on goods and services } \\
\text { and wages, including unpaid pensions and bonuses. }\end{array}$ & $\begin{array}{l}\text { Four weeks after the end of each } \\
\text { month. }\end{array}$ \\
\hline End-of-period stock of external arrears. & $\begin{array}{l}\text { Four weeks after the end of each } \\
\text { month. }\end{array}$ \\
\hline $\begin{array}{l}\text { Breakdown of expenditures recorded in the TOFE (goods and } \\
\text { services, wages, interest, etc.). }\end{array}$ & $\begin{array}{l}\text { Four weeks after the end of each } \\
\text { quarter. }\end{array}$ \\
\hline $\begin{array}{l}\text { Summary report on actual spending in priority sectors, including } \\
\text { health, education, and security. }\end{array}$ & $\begin{array}{l}\text { Four weeks after the end of each } \\
\text { quarter. }\end{array}$ \\
\hline $\begin{array}{l}\text { Breakdown of revenue by institution and economic } \\
\text { classification. }\end{array}$ & $\begin{array}{l}\text { Four weeks after the end of each } \\
\text { quarter. }\end{array}$ \\
\hline $\begin{array}{l}\text { Revenues and expenditures offset against each other without } \\
\text { cash payment (by expenditure and revenue type). }\end{array}$ & $\begin{array}{l}\text { Four weeks after the end of each } \\
\text { quarter. }\end{array}$ \\
\hline $\begin{array}{l}\text { Breakdown of external debt service and arrears, by interest and } \\
\text { principal and by principal creditor. }\end{array}$ & $\begin{array}{l}\text { Four weeks after the end of each } \\
\text { month. }\end{array}$ \\
\hline $\begin{array}{l}\text { Amount of new nonconcessional and concessional external } \\
\text { debt contracted or guaranteed by the government. }\end{array}$ & $\begin{array}{l}\text { Four weeks after the end of each } \\
\text { month. }\end{array}$ \\
\hline $\begin{array}{l}\text { Actual disbursements of project and program external financial } \\
\text { assistance, and external debt relief granted by external } \\
\text { creditors (including date, amount, and donor). }\end{array}$ & $\begin{array}{l}\text { Four weeks after the end of each } \\
\text { quarter. }\end{array}$ \\
\hline Stock of tax arrears and amount recovered. & $\begin{array}{l}\text { Four weeks after the end of each } \\
\text { quarter. }\end{array}$ \\
\hline $\begin{array}{l}\text { Indicators to assess overall economic trends, such as the } \\
\text { consumer price index, and oil product sales. }\end{array}$ & $\begin{array}{l}\text { Four weeks after the end of each } \\
\text { month. }\end{array}$ \\
\hline $\begin{array}{l}\text { Import/export flows (in volume and value), activity in the forestry } \\
\text { and mining sector. }\end{array}$ & $\begin{array}{l}\text { Four weeks after the end of each } \\
\text { quarter. }\end{array}$ \\
\hline A monthly report on the structure of petroleum prices. & $\begin{array}{l}\text { One week after the end of each } \\
\text { month. }\end{array}$ \\
\hline
\end{tabular}


Table 2. Central African Republic: Minimum Excises, Estimated VAT and Minimum Retail Prices of Petroleum Products, 2009-10

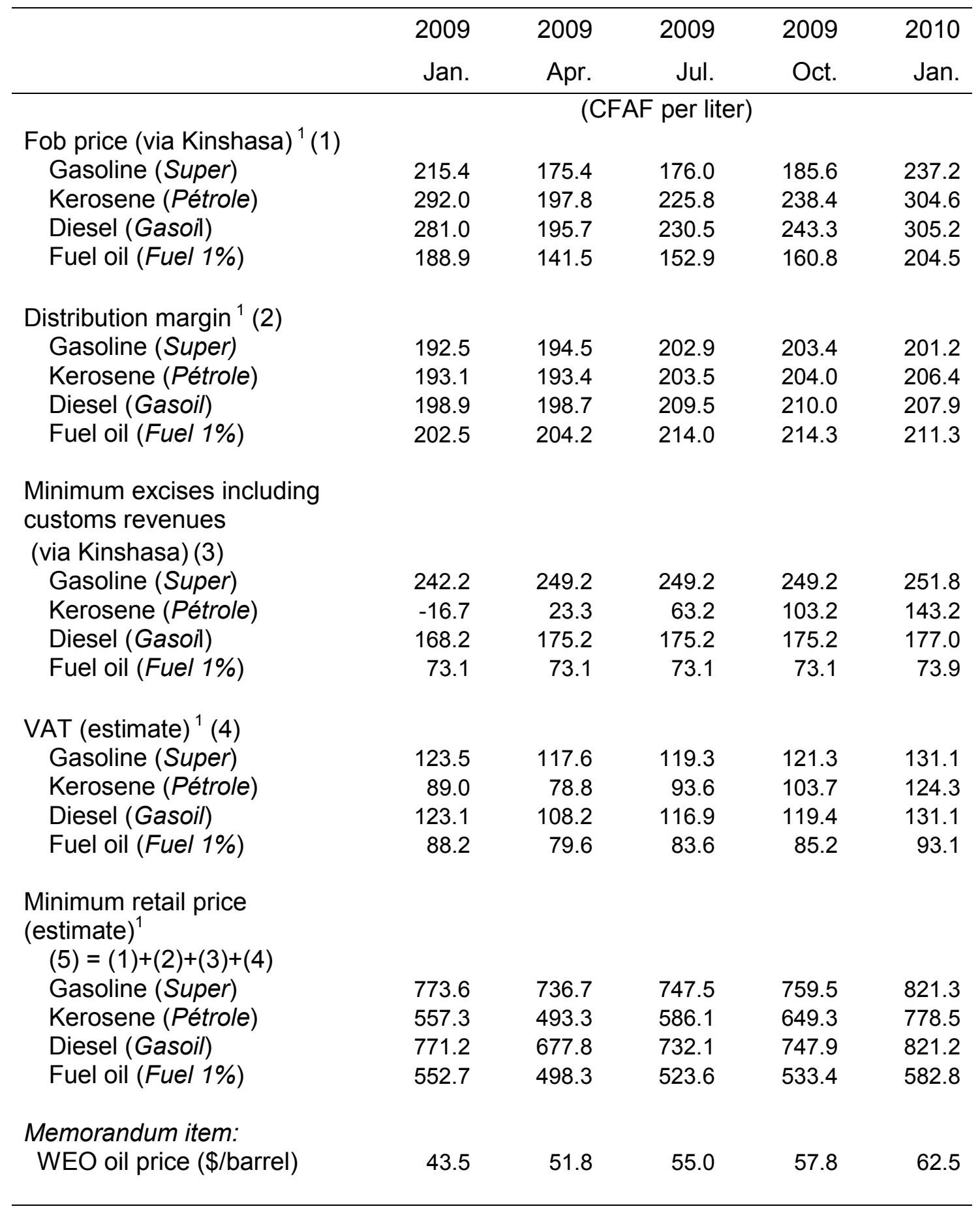

Sources: C.A.R. authorities; and IMF staff estimates.

${ }_{1}$ Estimates based on program projections for fob import prices based on a 90-day moving average. 
INTERNATIONAL MONETARY FUND

CENTRAL AFRICAN REPUBLIC

Fourth Review Under the Three-Year Arrangement Under the Poverty Reduction and Growth Facility, Request for Waivers for Nonobservance of Performance Criterion, Modification of Performance Criteria, Augmentation of Access, Extension of Time Under the Arrangement, and Financing Assurances Review

\section{Informational Annex}

Prepared by the African Department (in consultation with other departments)

Approved by Michael Atingi-Ego and Dhaneshwar Ghura

June 9, 2009

- $\quad$ Relations with the Fund. Describes financial and technical assistance by the IMF and provides information on the safeguards assessment and exchange rate system. Outstanding Fund credit was SDR 39.28 million (70.52 percent of quota) as of April 30, 2009.

- Joint Bank-Fund Work Program. Summarizes joint Bank-Fund Work Program for 2009-10. 
I. Relations with the Fund......................................................

II. Joint Bank-Fund Work Program................................................

Table

Recent Technical Assistance....................................................... 57 


\section{Appendix I}

Central African Republic

RELATIONS WITH THE FUND

(As of April 30, 2009)

I. Membership Status: Joined: 07/10/1963; Article VIII

II. General Resources Account:

Quota

Fund holdings of currency

Reserve position in Fund

III. SDR Department:

Net cumulative allocation

Holdings

IV. Outstanding Purchases and Loans:

PRGF arrangements $\begin{array}{rrr}\text { SDR million } & & \text { \% Quota } \\ 55.70 & & 100.00 \\ 55.53 & 99.69 \\ 0.18 & 0.32\end{array}$

$\frac{\text { SDR million }}{9.33} \frac{\text { Allocation }}{100.00}$

$0.04 \quad 0.44$

$\frac{\text { SDR million }}{39.28} \quad \frac{\% \text { Quota }}{70.52}$

Amount Amount Approval Expiration Approved Drawn

$\underline{\text { Type }}$

Date

Dec. 22, 2006

Date

Dec. 21, 2009

Jan. 19, 2002

Mar. 27, 1995

(SDR millions)

$\begin{array}{ll}44.56 & 35.26 \\ 49.44 & 24.48 \\ 16.48 & 10.71\end{array}$

PRGF

Stand-By
Jul. 20, 1998

Mar. 28, 1994

VI. Projected Payments to the Fund (without HIPC Assistance) ${ }^{5}$

(SDR million; based on existing use of resources and present holdings of SDRs):

Forthcoming

$\begin{array}{lllll}2009 & 2010 \quad 2011 & 2012 & 2013\end{array}$

Principal

Charges/interest

Total

\begin{tabular}{lllll}
1.62 & 1.60 & 0.80 & 1.76 & 5.01 \\
$\underline{0.22}$ & $\underline{0.22}$ & $\underline{0.22}$ & $\underline{0.21}$ & $\underline{0.19}$ \\
\hline 1.85 & 1.82 & 1.02 & 1.97 & 5.20
\end{tabular}

\footnotetext{
${ }^{5}$ When a member has overdue financial obligations outstanding for more than three months, the amount of such arrears will be shown in this section,
} 


\section{Implementation of HIPC Initiative:}

I. Commitment of HIPC Assistance

Enhanced

Decision point date

Framework

Assistance committed by all creditors (US\$ million) ${ }^{6}$

September 2007

Of which: IMF Assistance (US\$ million)

(SDR equivalent in millions)

Completion point date

Floating

II. Disbursement of IMF Assistance (SDR million)

$\begin{array}{ll}\text { Assistance disbursed to the member } & 6.59\end{array}$

$\begin{array}{ll}\text { Interim assistance } & 6.59\end{array}$

Completion point balance

Additional disbursement of interest income ${ }^{7}$

Total disbursements

VIII. Implementation of Multilateral Debt Relief Initiative (MDRI): Not applicable

IX. Safeguards Assessments: The Bank of the Central African States (BEAC) is the regional central bank of the Central African States. The most recent safeguards assessment of the BEAC was completed on August 30, 2004. In accordance with the four year cycle established for assessments of regional central banks, an update assessment was initiated in April 2008. The preliminary findings of this assessment indicate that implementation of previous safeguards recommendations on financial reporting, internal audit, and internal control has been limited, and that the changing risk profile of the BEAC foreign exchange holdings requires further actions to strengthen safeguards at the BEAC. Completion of the update assessment, however, requires an official response from the BEAC authorities that has yet to be received.

\section{Exchange Rate Arrangement}

The Central African Republic is a member of a monetary association with a common central bank, the BEAC. The exchange system common to all members operates without restrictions on the making of payments and transfers for current international transactions. The CFA

\footnotetext{
${ }^{6}$ Assistance committed under the original framework is expressed in net present value (NPV) terms at the completion point, and assistance committed under the enhanced framework is expressed in NPV terms at the decision point. Hence, these two amounts cannot be added.

${ }^{7}$ Under the enhanced framework, an additional disbursement is made at the completion point corresponding to interest income earned on the amount committed at the decision point but not disbursed during the interim period.
} 
franc is pegged to the euro at the fixed rate of CFAF $655.957=€ 1$. On April 30, 2009, the rate of the CFA franc in terms of SDRs was SDR 1 = CFAF 740.12.

\section{Article IV Consultations}

The Central African Republic is currently on the standard 24-month cycle for Article IV consultations for program countries. The last Article IV consultation was concluded on September 28, 2007.

\section{Resident Representative}

The Fund's office in Bangui reopened in October 2007 (after being closed in September 2003). The Resident Representative is Mr. Joseph Ntamatungiro. 
Table. Central African Republic: Recent Technical Assistance

\begin{tabular}{|c|c|c|}
\hline Date & Department & Purpose \\
\hline Apr. 2001 & FAD & $\begin{array}{l}\text { Follow-up on the introduction of the VAT and discuss measures } \\
\text { to improve tax and customs revenue collection. }\end{array}$ \\
\hline Jan.-Feb. 2004 & STA & $\begin{array}{l}\text { Review and follow-up of the General Data Dissemination } \\
\text { System (GDDS); TA in government finance statistics. }\end{array}$ \\
\hline Mar. 2004 & FAD & To assist the authorities in the area of revenue administration. \\
\hline Apr. 2004 & FAD & Public financial management. \\
\hline Aug.-Oct. 2004 & FAD & Tax administration. \\
\hline Feb.-Dec. 2005 & FAD & Public financial management. \\
\hline May 2005 & FAD & $\begin{array}{l}\text { Follow-up on implementation of tax administration reforms; } \\
\text { review of progress made since the end of the three-month } \\
\text { assignment of an FAD tax expert. }\end{array}$ \\
\hline Jun.-Jul. 2005 & STA & Government finance statistics. \\
\hline Jul. 2005 & STA & Real sector data. \\
\hline May 2006 & FAD & Recovery of tax arrears. \\
\hline May 2006 & FAD & Fax administration reform. \\
\hline Sep.-Oct. 2006 & STA & Monetary and financial statistics. \\
\hline $\begin{array}{l}\text { Jan. 2007-Aug. } \\
2008\end{array}$ & FAD & Public financial management. \\
\hline Apr.-May 2007 & FAD & $\begin{array}{l}\text { Fiscal implications of alternative fuel pricing policies and their } \\
\text { distributional impact on vulnerable household groups, including } \\
\text { mitigating measures. }\end{array}$ \\
\hline Oct. 2007 & AFRITAC/FAD & $\begin{array}{l}\text { Custom administration; and follow-up on the new customs } \\
\text { organizational structure. }\end{array}$ \\
\hline Oct. 2007 & AFRITAC/FAD & $\begin{array}{l}\text { Follow up on implementation of tax administration reforms and } \\
\text { review of progress made since the expert's previous visit in } \\
\text { May } 2006 \text {. }\end{array}$ \\
\hline Nov.-Dec. 2007 & FAD & Inspection of FAD resident PFM advisor. \\
\hline Dec. 2007 & AFRITAC/STA & National account data. \\
\hline Mar. 2008 & $\begin{array}{l}\text { AFRITAC } \\
/ \text { MCM }\end{array}$ & Debt management. \\
\hline Jun. 2008 & AFRITAC & Follow-up on implementation of tax administration \\
\hline Jun. 2008 & AFRITAC & Follow-up on implementation of customs administration \\
\hline Aug. 2008 & AFRITAC/STA & National account data. \\
\hline Sep. 2008 & AFRITAC & Public financial management. \\
\hline Sep.-Oct. 2008 & AFRITAC/FAD & $\begin{array}{l}\text { Introduction of new accounting framework and budget } \\
\text { classification system. }\end{array}$ \\
\hline Oct. 2008 & AFRITAC & Tax collection and use of tax administration information. \\
\hline Jan. 2009 & AFRITAC & Follow-up on implementation of tax collection reform measures. \\
\hline Mar. 2009 & AFRITAC/FAD & Accounting procedures reforms. \\
\hline Mar. 2009 & AFRITAC & Elaboration of public debt management manual. \\
\hline Mar. 2009 & AFRITAC & Improvement in the coordination of customs procedures. \\
\hline May 2009 & AFRITAC/FAD & $\begin{array}{l}\text { Progress of tax administration reforms and formulate medium- } \\
\text { term reform strategy. }\end{array}$ \\
\hline May 2009 & AFRITAC & National account data. \\
\hline
\end{tabular}




\section{APPENDIX II}

\section{Central African Republic \\ JoInT BANK-Fund WORK PROGRAM, 2009-10}

\begin{tabular}{|c|c|c|c|}
\hline Title & Products & $\begin{array}{l}\text { Provisional timing } \\
\text { of missions }\end{array}$ & $\begin{array}{l}\text { Actual or Expected } \\
\text { delivery date }\end{array}$ \\
\hline \multicolumn{4}{|c|}{ A. Mutual information on relevant work programs } \\
\hline \multirow{4}{*}{$\begin{array}{l}\text { World Bank } \\
\text { work program } \\
\text { in the next } \\
12 \text { months }\end{array}$} & $\begin{array}{l}\text { Country Partnership Strategy (CPS) joint with } \\
\text { AfDB }\end{array}$ & November 2008 & July 2009 \\
\hline & $\begin{array}{l}\text { DPO III } \\
\text { - Budget support }\end{array}$ & December 2008 & March 2009 \\
\hline & $\begin{array}{l}\text { Response to the Energy Crisis } \\
\text { - The project aims to restore reliable electricity } \\
\text { supply to ENERCA's customers in Bangui by } \\
\text { addressing maintenance and rehabilitation of } \\
\text { three diesel units at the Bangui Thermal Power } \\
\text { Station; Replacement of a } 10 \mathrm{MW} \text { transformer } \\
\text { at Boali 1; introduction of more efficient } \\
\text { lighting devices and Loss Reduction Program }\end{array}$ & October 2008 & February 2009 \\
\hline & $\begin{array}{l}\text { Vulnerable Groups Community Development } \\
\text { - The project aims to improve basic local } \\
\text { government services, especially for } \\
\text { rehabilitation, capacity building and equipping } \\
\text { of health and education centers in } 9 \text { of the } \\
\text { country's } 16 \text { regions. }\end{array}$ & & March 2009 \\
\hline \multirow[t]{5}{*}{$\begin{array}{l}\text { IMF work } \\
\text { program in the } \\
\text { next } 12 \text { months }\end{array}$} & $\begin{array}{l}\text { Macroeconomic policy analysis and advice } \\
\text { - Fifth PRGF review and Article IV consultation } \\
\text { - Sixth PRGF review }\end{array}$ & $\begin{array}{l}\text { September } 2009 \\
\text { March } 2010\end{array}$ & $\begin{array}{l}\text { December } 2009 \\
\text { June } 2010\end{array}$ \\
\hline & $\begin{array}{l}\text { Technical assistance } \\
\text { - Revenue administration }\end{array}$ & $\begin{array}{l}\text { January } 2009 \\
\text { March } 2009 \\
\text { May } 2009(\mathrm{HQ})\end{array}$ & \\
\hline & - Public debt management & $\begin{array}{l}\text { March } 2009 \\
\text { Q3 } 2009 \text { (HQ) }\end{array}$ & \\
\hline & - Public financial management & $\begin{array}{l}\text { May } 2009 \\
\text { Q4 } 2009\end{array}$ & \\
\hline & - Statistics & $\begin{array}{l}\text { July } 2009 \\
\text { August } 2009\end{array}$ & \\
\hline \multicolumn{4}{|c|}{ B. Requests for work program inputs } \\
\hline $\begin{array}{l}\text { Fund request to } \\
\text { Bank }\end{array}$ & Periodic update on progress & & \\
\hline $\begin{array}{l}\text { Bank request to } \\
\text { Fund }\end{array}$ & $\begin{array}{l}\text { Regular update of medium-term macroeconomic } \\
\text { framework covering the period until } 2014\end{array}$ & & \\
\hline \multicolumn{4}{|c|}{ C. Agreement on joint products and missions } \\
\hline $\begin{array}{l}\text { Joint products in } \\
\text { the next } \\
12 \text { months }\end{array}$ & $\begin{array}{l}\text { - Joint Debt Sustainability Analysis } \\
\text { - HIPC completion point document }\end{array}$ & $\begin{array}{l}\text { April } 2009 \\
\text { April } 2009\end{array}$ & $\begin{array}{l}\text { June } 2009 \\
\text { June } 2009\end{array}$ \\
\hline
\end{tabular}


Press Release No. 09/242

FOR IMMEDIATE RELEASE

International Monetary Fund

June 29, 2009

Washington, D.C. 20431 USA

\section{IMF Executive Board Completes Fourth Review Under PRGF Arrangement for the Central African Republic and Approves Extension and US\$38.7 Million Increase}

The Executive Board of the International Monetary Fund (IMF) today completed the fourth review of the Central African Republic's economic performance under a program supported by the arrangement under the Poverty Reduction and Growth Facility (PRGF), and approved a six-month extension and an increase of access by an amount equivalent to SDR 25.065 million (about US\$38.7 million). The Executive Board granted a waiver for nonobservance of an end-December 2008 quantitative performance criterion on the ceiling on change in net claims of the commercial banking system on the government. The Executive Board also approved a review of the country's financing assurances.

A three-year PRGF arrangement for the Central African Republic was approved on December 22, 2006 (see Press Release No 06/299) to support the government's economic program through December 2009. Wednesday's decision increases the overall value of IMF funding for the arrangement to an amount equivalent to SDR 69.62 million (about US\$107.5 million) and extends the arrangement to June 30, 2010. Of that, an amount equivalent to SDR 14.24 million (about US\$21.99 million) is now available for disbursement.

Major shocks including electricity outages due to breakdowns at the main hydro power plant and a plunge in timber and diamond exports reduced the Central African Republic's economic growth to 2.2 percent in 2008 . Nevertheless, fiscal performance was satisfactory, with an increase in the tax-to-GDP ratio.

Growth in 2009 is expected to rise only marginally to $2 \frac{1}{2}$ percent, significantly lower than previously expected. With a drop in exports, which are now projected to be 40 percent down on initial expectations, and reduced private financial inflows, official foreign reserves are projected to drop to 2.6 months of imports even with the increased access approved by the Executive Board on Monday.

Following the Executive Board's discussion, Mr. Takatoshi Kato Deputy Managing Director and Acting Chair, stated: 
" The Central African Republic (C.A.R.) authorities are to be commended for the satisfactory implementation of their program under the PRGF. The C.A.R. authorities have made important progress in improving economic management and strengthening the country's resilience to shocks. Fiscal operations have become more credible through mobilization of domestic revenues and prudent budget execution. The implementation of the automatic petroleum pricing formula has been critical in insulating the budget from fluctuations in world oil prices and securing revenues. Looking ahead, steadfast implementation of the authorities' medium-term economic and financial reform program to strengthen fiscal management and foster private sector activities should support a recovery in economic growth and further progress in reducing poverty.

" The C.A.R. authorities are determined to improve the security situation and preserve political stability by implementing an inclusive peace-building process with external assistance. Accommodating the additional donor-financed spending for peace building will support these efforts and help stimulate demand and mitigate the impact of the global slowdown.

“ A final decision on C.A.R.'s debt relief under the enhanced HIPC Initiative and the MDRI is still pending action this week by the World Bank's Executive Board. A press release will be issued jointly with the Bank following those deliberations", added Mr. Kato.

The PRGF is the IMF's low-interest lending facility for low-income countries. PRGFsupported programs are underpinned by comprehensive country-owned poverty reduction strategies. 


\section{Statement by Mr. Rutayisire, Executive Director for Central African Republic June 29, 2009}

On behalf of my Central African Republic (C.A.R) authorities, I would like to thank Management and Staff for the continued close and constructive dialogue with them and the financial and technical assistance provided to the C.A.R.

The continued Fund engagement in C.A.R has enabled my authorities to steadily progress from the decision point to this day when the authorities have accomplished all the conditions needed to reach the completion point and benefit from enhanced HIPC debt relief and MDRI.

With a significant share of non Paris-Club creditors in C.A.R's debt structure, it has been has always been difficult for CAR authorities to secure the creditor participation rate needed under the enhanced HIPC initiative. Directors would recall that at the time of the decision point, C.A.R had managed to secure a 68 percent creditor participation rate. Thanks to the intervention of the French authorities at the last minute, French public-private enterprises agreed to participate, which allowed C.A.R to reach the 70 percent creditors needed for Interim Assistance and the decision point. This time around, in spite of having satisfactorily implemented their PRGF program and HIPC completion point conditions, my authorities had until June 24, 2009 managed to secure only 78 percent creditors participation rate. Today, because of the intervention of Argentinean authorities, the CAR authorities have been able to attain the 80 percent creditors participation rate threshold needed for reaching the Completion Point.

I wish to thank Executive Directors for all their efforts in convincing their authorities to provide debt relief to C.A.R. In particular, I would like to thank the Argentineans, French and British authorities for their decisive support to C.A.R; I also acknowledge and thank Management and Staff for their invaluable support in this process.

\section{Progress Under The PRGF PROGRAM}

The Central African Republic 's economic development has been constrained for many years by socio-political instability. Soon after President Bozizé was sworn-in following democratic elections in 2005, he embarked on efforts to consolidate peace and restore security with the assistance from the international community. The authorities' steadfast efforts culminated with the Security Sector Reforms and the Inclusive Political Dialogue national conferences which led to the formation of a coalition government including representatives from the civil society, the political opposition as well as rebel groups. My authorities' priorities going forward are to build on this achievement through implementation of the agreed upon 
Disarmament, Demobilization, and Reinsertion (DDR) program as well as the recommendations of the Security Sector Reform, in line with their Poverty Reduction Strategy. The HIPC and MDRI debt relief would go a long way in supporting my authorities efforts.

On the economic front, the Central African Republic has faced repeated exogenous shocks during the period covered by this program review, including sharp food and oil price increases, and the global downturn. In addition, electricity outages, and limited capacities have constrained the country's growth prospects. Despite these severe challenges, my authorities have made significant strides in rebuilding the economy and strengthening their capacity to address the pressing development and humanitarian needs of the population.

Their commitment to implementing sound policies is born out by their performance under the PRGF-supported program. They observed all the quantitative performance criteria except for the ceiling on commercial bank borrowing. This criteria was narrowly missed because of a delay in the transfer of an IMF disbursement from the regional Central Bank (BEAC) to the Central African Republic. Accordingly, my C.A.R. authorities request a waiver for the nonobservance of this performance criterion.

Looking forward, there remain significant challenges which my authorities are fully cognizant of. Based on the continued progress being made by the authorities and their commitment to sound policies going forward, I will appreciate Directors' support of (i) the completion of the fourth review under the PRGF arrangement, (ii) extension of the program until June 30, 2010 to provide them time to adjust their policies and allow the remaining reviews of the program to take place on a biannual basis,(iii) review of the financing assurances, and (iv) modification of the structural performance criterion on petroleum pricing mechanism in order to conform to the Board's decision on structural conditionality

In addition, my authorities request (i) an augmentation of access to help them face balanceof-payments needs, and (ii) modifications of quantitative performance criteria on the floors for fiscal revenue and balance and for change in net claims of commercial banks on the government, reflecting the impact of the global crisis.

\section{ENHANCED HIPC COMPLETION POINT AND MDRI}

As appraised in the JSAN and the Completion point document, my authorities have satisfactorily implemented the requirements for reaching the completion point under the enhanced HIPC initiative. They have realized all completion point triggers, including in public financial and debt management, and have implemented for more than one year a sound Poverty Reduction Strategy as evidenced by their PRSP's Annual Progress Report. Moreover, as discussed above, the C.A.R authorities have secured the participation of more than 80 percent of their creditors to the debt relief effort under HIPC terms. Accordingly they 
request Director's support to reach the completion point under the enhanced HIPC Initiative, and additional MDRI/HIPC debt relief from the IMF.

\section{Prospects For 2009 ANd Medium Term Policies}

My authorities plan to adjust to the evolving and challenging external environment while steadfastly implementing their medium-term reform agenda. In particular:

On fiscal policy, my authorities will intensify their efforts aimed at creating the fiscal space required to strengthen the economy's resilience to shocks and promote their poverty reduction strategy while preserving medium-term fiscal sustainability. They plan to achieve this objective through reforms aimed at improving revenue mobilization, increasing priority spending as well as spending efficiency, including through public financial management reforms, and the use of medium-term expenditure frameworks.

On debt sustainability, my authorities have made significant progress in improving their debt management capabilities by, amongst other measures, setting up a computerized debt management system, a comprehensive debt database, and the establishment of a debt department able to publish annual debt statistics bulletins and timely debt service projections.

Full delivery of HIPC debt relief, MDRI and additional bilateral assistance would considerably reduce C.A.R external public debt and free up resources needed to meet their development agenda. My authorities are committed to building on the progress achieved so far to implement sound debt strategies with a view to further reducing public indebtedness in the medium term. This strategy will include the clearance of domestic debt arrears, the recourse to highly concessional loans or grants as regards external borrowing, and a strengthened legal framework for sovereign borrowing.

Regarding the financial sector, my authorities will further promote financial development and stability in line with the recommendations made by the FSAP. Given the significant exposure of the banking system to government borrowing, banks' balance sheets are expected to improve as the authorities follow through on their plans to clear domestic arrears.

On structural reforms, my authorities are committed to intensify their efforts to lay the foundation for economic stability and a broadbased, private sector-led growth. They are striving to remove the constraints to growth posed by the electricity shortages and other infrastructural bottlenecks. To that effect, they will seek to improve the financial performance of the utilities companies and reduce cross payment arrears. On governance, my authorities are committed to intensify their efforts to increase transparency and the rule of law, and reduce corruption. They will continue implementing strong disclosure standards for senior public officials, as well as reforms aimed at increasing accountability. The anticorruption initiatives they have launched have already led to improvements in the CAR's 
ranking in Transparency International Index. My authorities are also determined to undertake further reforms to improve the business climate notably in the natural resources sector, through continued adhesion to the EITI and the implementation of the new forestry and mining codes, with the view to helping attract FDI and stimulate private investment.

\section{CONCLUSION}

The C.A.R authorities have achieved significant gains in their efforts to consolidate peace and security, macroeconomic stability and post-conflict economic recovery, with the invaluable assistance of the international community, including the IMF. As results of their actions, the economy's resilience to shocks is improving; macroeconomic management is being enhanced and strides are being made in achieving the country's poverty reduction objectives.

Significant challenges, however, lie ahead for the C.A.R, both in the short and long run, including limited capacities, significant humanitarian and development needs, and a particularly difficult adverse world economic environment. These risks warrant a strong support from the international community to supplement my authorities' efforts.

In light of the challenges ahead, and the demonstrated good performance in implementing the PRGF program and the HIPC floating completion point triggers, I would appreciate Directors' support in the approval of my authorities requests. 